
Chapter E

\title{
Geologic History and Hydrocarbon Potential of Late Cretaceous-Age, Low-Permeability Reservoirs, Piceance Basin, Western Colorado
}

\author{
By RONALD C. JOHNSON
}

A multidisciplinary approach to research studies of sedimentary rocks and their constituents and

the evolution of sedimentary basins, both ancient and modern

U.S. GEOLOGICAL SURVEY BULLETIN 1787

EVOLUTION OF SEDIMENTARY BASINS-UINTA AND PICEANCE BASINS 


\title{
DEPARTMENT OF THE INTERIOR DONALD PAUL HODEL, Secretary
}

\author{
U.S. GEOLOGICAL SURVEY \\ Dallas L. Peck, Director
}

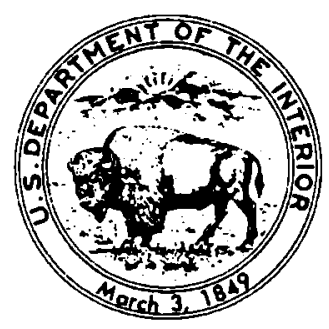

UNITED STATES GOVERNMENT PRINTING OFFICE: 1989

For sale by the

Books and Open-File Reports Section

U.S. Geological Survey

Federal Center, Box 25425

Denver, CO 80225

Any use of trade names in this report is for descriptive purposes only and does not imply endorsement by the U.S. Geological Survey.

Library of Congress Cataloging-in-Publication Data

Johnson, Ronald Carl, 1950-

Geologic history and hydrocarbon potential of Late Cretaceous-Age,

low-permeability reservoirs, Piceance Basin, western Colorado.

(Evolution of sedimentary basins-Uinta and Piceance Basins ; ch. E.) (U.S.

Geological Survey bulletin ; 1787)

Bibliography: $p$.

Supt. of Docs. no.: I 19.3:1787-E

1. Geology-Colorado-Piceance Creek Watershed. 2. Gas, Natural-Geology-Colorado-Piceance Creek Watershed. I. Title. II. Series.

III. Series: U.S. Geological Survey bulletin ; 1787-E.

QE75.B9

no. $1787-E \quad 557.3 \mathrm{~s} \quad\left[553.2^{\prime} 8^{\prime} 09788\right]$

$88-600282$

[QE92.P47] 


\section{CONTENTS}

Abstract $\quad$ E1

Introduction E1

Geologic setting E2

Mesaverde stratigraphy and general environments of deposition $\quad$ E8

Marine transgressions and regressions $\quad$ E8

Fluvial deposition $\quad$ E18

The Cretaceous-Tertiary unconformity E21

Oil and gas production in the Mesaverde E23

Extent of the Mesaverde low-permeability gas accumulation $\quad$ E23

Mesaverde reservoir properties $\quad$ E28

The role of natural fractures in Mesaverde gas production $\quad \mathbf{E 3 0}$

Formation pressures in the Mesaverde E31

Origin of the Mesaverde low-permeability gas accumulation $\quad \mathbf{E 3 4}$

Geologic history of the Piceance basin as related to reservoir distribution and gas generation E36

Potential for future Mesaverde gas production $\quad$ E45

Discussion $\mathbf{E 4 5}$

References cited $\mathbf{E 4 7}$

\section{PLATES}

[In pocket]

1. Cross sections showing lithologies, environments of deposition, and results of drill-stem tests and perforations, Piceance basin, Colorado.

2. Detailed measured sections, Piceance basin, Colorado.

\section{FIGURES}

1-3. Maps showing:

1. Location of Piceance basin, Cretaceous epeiric seaway, and Sevier orogenic belt $\mathbf{E 2}$

2. Basins and uplifts created during Laramide orogeny, Utah, northwestern Colorado, and Wyoming E3

3. Structure contours of top of Rollins Sandstone Member of the Mesaverde Formation and equivalent Trout Creek Sandstone Member of the Iles Formation E4

4. Generalized stratigraphic charts of Mesaverde Formation or Group, Piceance basin and eastern Uinta basin E6

5-15. Maps showing:

5. Limits of Mesaverde regressive cycles E9

6. Limits of Mancos transgressive shale tongues E10

7. Total coal thickness in Cameo-Fairfield coal zone E15

8. Coal rank near base of Cameo-Fairfield coal zone E16

9. Mesaverde gas fields as of 1977 E25

10. Mesaverde gas fields as of 1981 E26 
11. Mesaverde gas fields as of $1984 \quad$ E27

12. Results of selected drill-stem tests and perforation recoveries for Mesaverde regressive marine cycles E28

13. Results of selected drill-stem tests and perforation recoveries for the fluvial part of Mesaverde Formation, including the Cameo-Fairfield coal zone E29

14. Potentiometric elevations and formation temperatures calculated for Corcoran, Cozzette, and Rollins or Trout Creek Members $\quad$ E33

15. Total calculated volume of methane produced by the Cameo-Fairfield zone E37

16. Schematic cross section drawn along trough of basin showing model for development of Piceance basin $\mathbf{E 3 8}$

17. Schematic cross section drawn perpendicular to trough of basin $\mathbf{E 3 9}$

18-20. Maps showing area of Mesaverde outcrop in:

18. Piceance basin near end of Cretaceous-Tertiary hiatus $\mathbf{E 4 0}$

19. Piceance basin immediately prior to deposition of lower Eocene Long Point Bed E41

20. Piceance basin between end of Laramide orogeny and about $10 \mathrm{~m} . \mathrm{y}$. ago $\mathbf{E 4 3}$

TABLES

1. Mesaverde oil and gas production through $1985 \quad$ E24

2. Wells in which the Mesaverde appears to be overpressured $\mathbf{E 3 2}$

3. Volumes of methane produced by coals of various ranks E36

CONVERSION FACTORS FOR SOME SI METRIC AND U.S. UNITS OF MEASURE

\begin{tabular}{lll}
\hline \multicolumn{1}{c}{ To convert from } & \multicolumn{1}{c}{ To } & \multicolumn{1}{c}{ Multiply by } \\
\hline Feet (ft) & Meters $(\mathrm{m})$ & 0.3048 \\
Miles (mi) & Kilometers (km) & 1.609 \\
Pounds (lb) & Kilograms (kg) & 0.4536 \\
Degrees Fahrenheit $\left({ }^{\circ} \mathrm{F}\right)$ & Degrees Celsius $\left({ }^{\circ} \mathrm{C}\right)$ & Temp $^{\circ} \mathrm{C}=\left(\right.$ temp $\left.{ }^{\circ} \mathrm{F}-32\right) / 1.8$ \\
\hline
\end{tabular}




\title{
Geologic History and Hydrocarbon Potential of Late Cretaceous-Age, Low-Permeability Reservoirs, Piceance Basin, Western Colorado
}

\author{
By Ronald C. Johnson
}

\begin{abstract}
The Piceance basin of western Colorado contains large reserves of natural gas in low-permeability reservoirs of the Late Cretaceous-age Mesaverde Formation or Mesaverde Group. The gas accumulation can be divided into three general zones: a zone of surface-water invasion that extends inward a few miles from present outcrops, a gas-and-waterbearing zone that extends 10-20 miles inward from the water-bearing zone, and a central, predominantly gasbearing zone. The Mesaverde low-permeability gas accumulation in the Piceance basin probably formed as a result of early loss of permeability due to intense regional diagenesis, followed by deep burial beneath lower Cenozoic sediments that resulted in large-scale thermal gas generation by the organic-rich intervals in the Mesaverde and in the underlying Mancos Shale. Although the early loss of permeability trapped much of the gas in deep central areas of the basin, considerable amounts of gas also migrated updip into the shallower areas of the basin where the Mesaverde is thermally immature. This migration may have been enhanced by an extensive natural fracture system.

Reconstruction of the geologic history of both the Piceance basin and surrounding uplifts helped define conditions under which the gas accumulation formed. The Mesaverde was deposited in nearshore and coastal-plain environments during the Late Cretaceous while the Cretaceous epeiric seaway was gradually being filled in. Blanketlike and near-blanketlike sandstone reservoirs are common in the transgressive and regressive cycles in the lower part of the Mesaverde, whereas mainly lenticular sandstone reservoirs are in the coastal-plain sediments of the upper part of the Mesaverde.
\end{abstract}

Publication approved by the Director, U.S. Gcological Survey, May 27, 1988.
Intense early diagenesis of Mesaverde rocks resulted in part from their long-term exposure to surface weathering prior to the onset of basin subsidence during the Paleocene. Once basin subsidence began during the Paleocene, the Mesaverde was buried beneath younger sediments except for a ring of Mesaverde outcrops adjacent to the surrounding Laramide uplifts that persisted throughout the Laramide orogeny and still exist today. These outcrops stood as high as several thousand feet above the basin floor during the Laramide orogeny and acted as conduits for fluid movement in and out of the Mesaverde.

Gas began to accumulate during the early Eocene in the deepest part of the basin, at which time formation temperatures in the lower part of the Mesaverde were $250^{\circ} \mathrm{F}$ or greater. Prior to this time, regional diagenesis must have reduced permeabilities to low levels. As basin subsidence continued, the area of thermal gas continued to expand until, near the end of the Eocene, gas was being generated by at least the lower part of the Mesaverde throughout much of the basin. The area of significant methane generation possibly shrank somewhat during the final stages of the Laramide orogeny when marginal areas of the basin were uplifted and beveled. During the middle and late Cenozoic, several intrusive and extrusive events in the southern part of the basin temporarily increased the rate of methane generation. Methane generation continued throughout much of the basin until about 10 m.y. ago, at which time formation temperatures were significantly reduced as a result of downcutting of the Colorado River canyon system. At present, significant amounts of methane are probably being generated in relatively restricted areas in the deeper parts of the basin.

\section{INTRODUCTION}

The Piceance basin of western Colorado is one of sevcral Rocky Mountain basins created during the Laramide orogeny that contain a thick sequence of gas- 
bearing, low-permeability reservoirs of Cretaceous age. These unconventional gas accumulations are in vast areas of the structurally deeper parts of these Rocky Mountain basins and differ from conventional oil and gas deposits in that they cut across stratigraphic units, commonly are structurally downdip from more permeable water-filled reservoirs, have no obvious structural or stratigraphic trapping mechanism, and commonly are either abnormally overpressured or underpressured. In the central core of these gas accumulations, all rocks, including sandstones, siltstones and shales, appear to be gas saturated (Masters, 1979). These clastic-rich Cretaccous reservoirs are believed to contain enormous reserves of natural gas, and the National Petroleum Council (1980, p. 31) estimates 32 trillion cubic feet of recoverable natural gas in the Piceance basin. During the last 20 years, many attempts have been made to develop these resources by using innovative completion techniques including nuclear techniques.

Since 1977, the U.S. Department of Energy (DOE) has supported comprehensive tight-gas sand research in the Uinta basin of Utah and Colorado, the Piceance basin of Colorado, the greater Green River basin of Wyoming, Colorado, and Utah, and the northern Great Plains of Montana. This research includes regional studies of stratigraphy, structure, sedimentary environments, thermal maturity, petrography, X-ray mineralogy, hydrocarbon source rocks, fractures, and drill-stem test and perforation results. The regional studies are complemented by detailed core analysis. In 1981, DOE began a comprehensive study at the Multiwell Experiment (MWX) site, located in the Rulison gas field west of Rifle, Colo. At this site, three closely spaced wells were drilled in a triangular pattern. Core was cut of nearly all of the Upper Cretaceous Mesaverde Group rocks intersected and was studied in great detail. A U.S. Geological Survey (USGS) open-file report (Spencer and Keighin, 1984) summarizes much of the USGS work conducted at MWX.

The present report attempts to integrate some of the detailed geologic studies from the Multiwell Experiment and the more regional geologic studies in an effort to improve our understanding of the geologic variables involved in the development of the Mesaverde low-permeability gas accumulation in the Piceance basin. This synthesis relies heavily on published studies, but much new information is also presented.

Acknowledgments. - The studies on which this report is based were funded by the U.S. Department of Energy Western Tight Gas Sands Program and the USGS Evolution of Sedimentary Basins Program.
Technical revicwers Michael Brownfield, Richard Scott, and Karen Franczyk made helpful suggestions that greatly improved the manuscript.

\section{GEOLOGIC SETTING}

The Piceance basin in western Colorado is a structural and sedimentary basin created by Laramide tectonism from latest Cretaceous through Paleocene time (fig. 1). It is bounded on the northwest by the Uinta uplift, on the north by the Axial basin anticline, on the east by the White River uplift, on the southeast by the Sawatch uplift, on the south by the San Juan volcanic field, and on the southwest by the Uncompahgre uplift (fig. 2). It is separated from the Uinta basin of early Cenozoic age to the west by the Douglas Creek arch. At times during the early Cenozoic, the Douglas Creek arch divided the Uinta and Piceance basins into two separate sedimentary basins; at other times, sediments buried the arch, creating one large basin (Johnson, 1985a; Johnson and Finn, 1985, 1986).

The Piceance basin is highly asymmetrical and has gently dipping western and southwestern flanks and a sharply upturned eastern flank (fig. 3). The eastern flank, called the Grand Hogback, is believed to be underlain by a deep-seated west-thrusting reverse or thrust fault (Gries, 1983). The Grand Hogback also forms the western boundary of the White River uplift. A huge

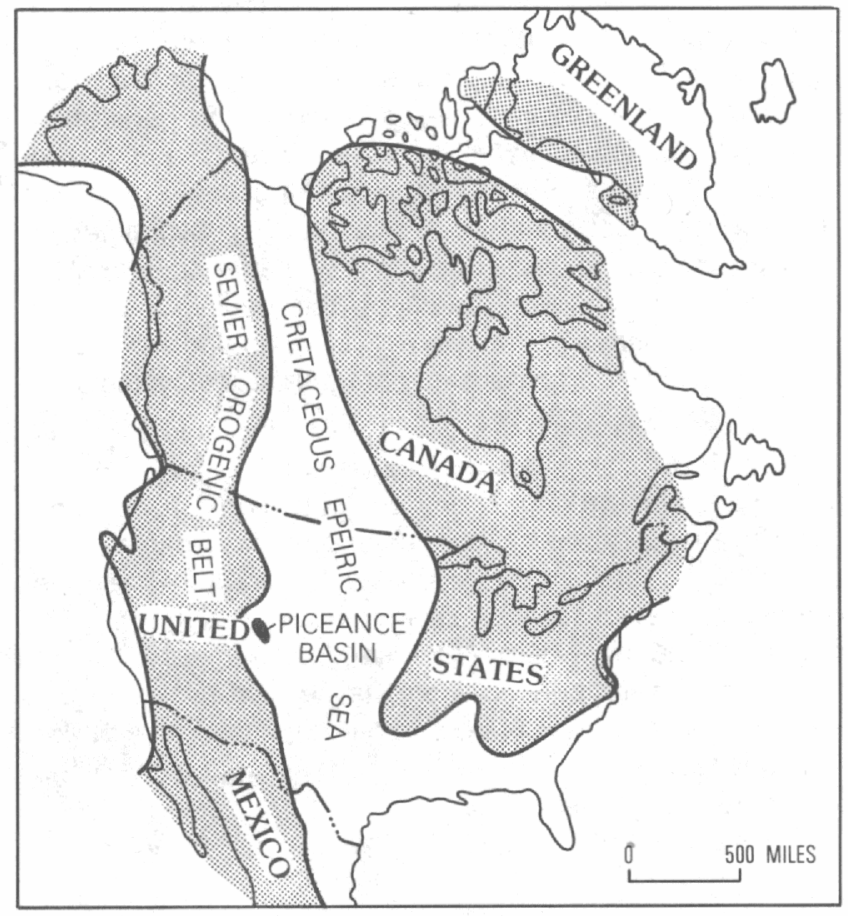

Figure 1. Location of Piceance basin, Cretaceous epeiric seaway, and Sevier orogenic belt. Areas above sea level patterned. 


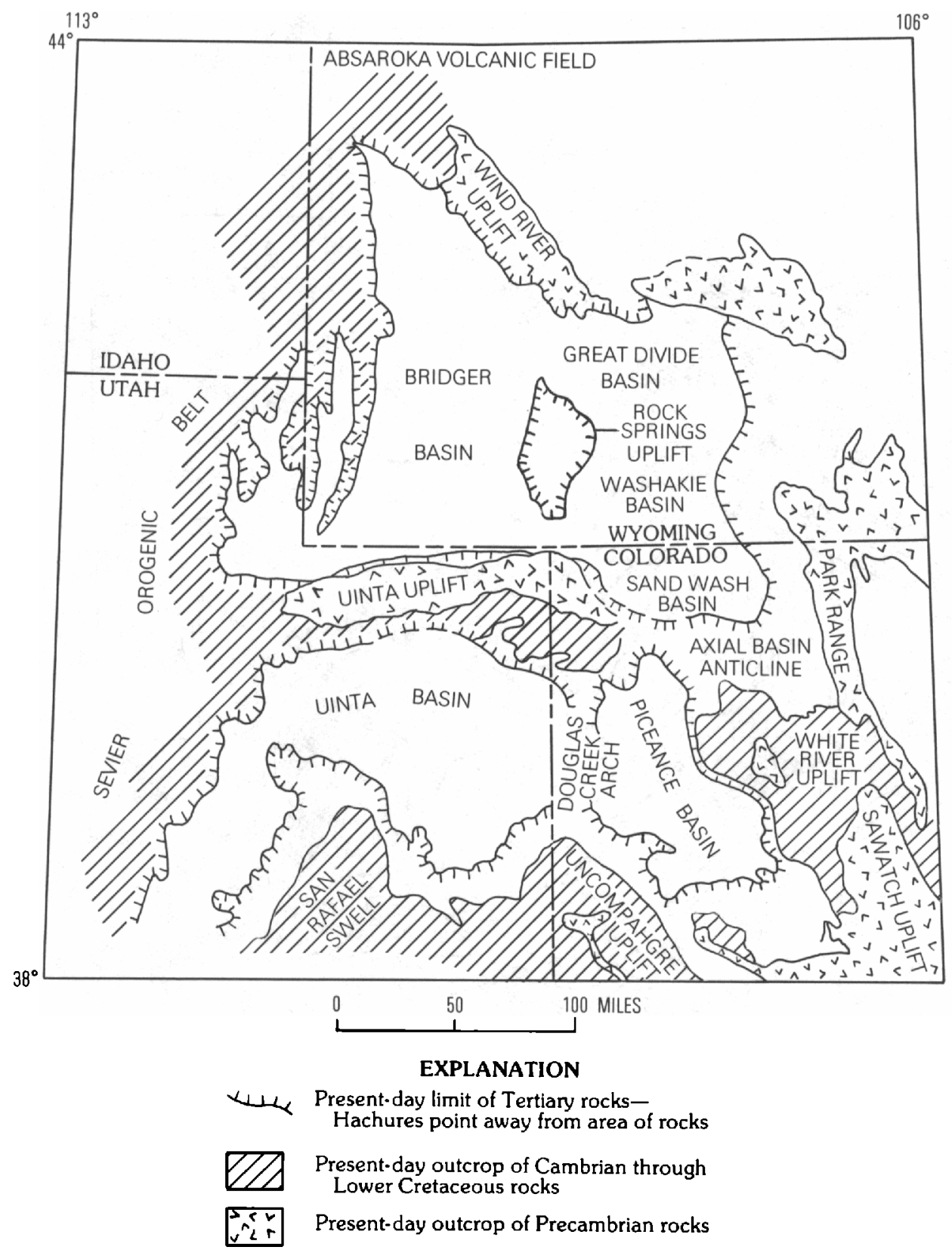

Figure 2. Basins and uplifts created during Laramide orogeny in northeastern Utah, northwestern Colorado, and southwestern Wyoming. San Juan volcanic field located south of Sawatch uplift.

southeast-plunging anticline in the northern part of the basin, the central part of which is called the White River dome, almost separates the northernmost part of the basin from the rest of the Piceance basin (fig. 3). Another southeast-plunging anticline, the Rangely anticline, is south and west of the White River dome and forms the northern terminus of the Douglas Creek arch. The Rangely anticline is the only giant oil field in Colorado and produces oil from the Pennsylvanian and Permian Weber Sandstone and the Upper Cretaceous Mancos Shale. The White River dome has produced some gas out of both the Upper Cretaceous Mesaverde Formation and the Paleocene and Eocene Wasatch Formation. Both the Rangely anticline and the White River dome are probably subsidiary anticlines related to the eastern terminus of the Uinta uplift. They are believed to be underlain by major southwest-thrusting high-angle reverse or thrust faults related to the more major thrust fault along the southern margin of the Uinta uplift (Gries, 1983).

In the southeastern part of the basin, three large closed anticlines, the Divide Creek, Wolf Creek, and 

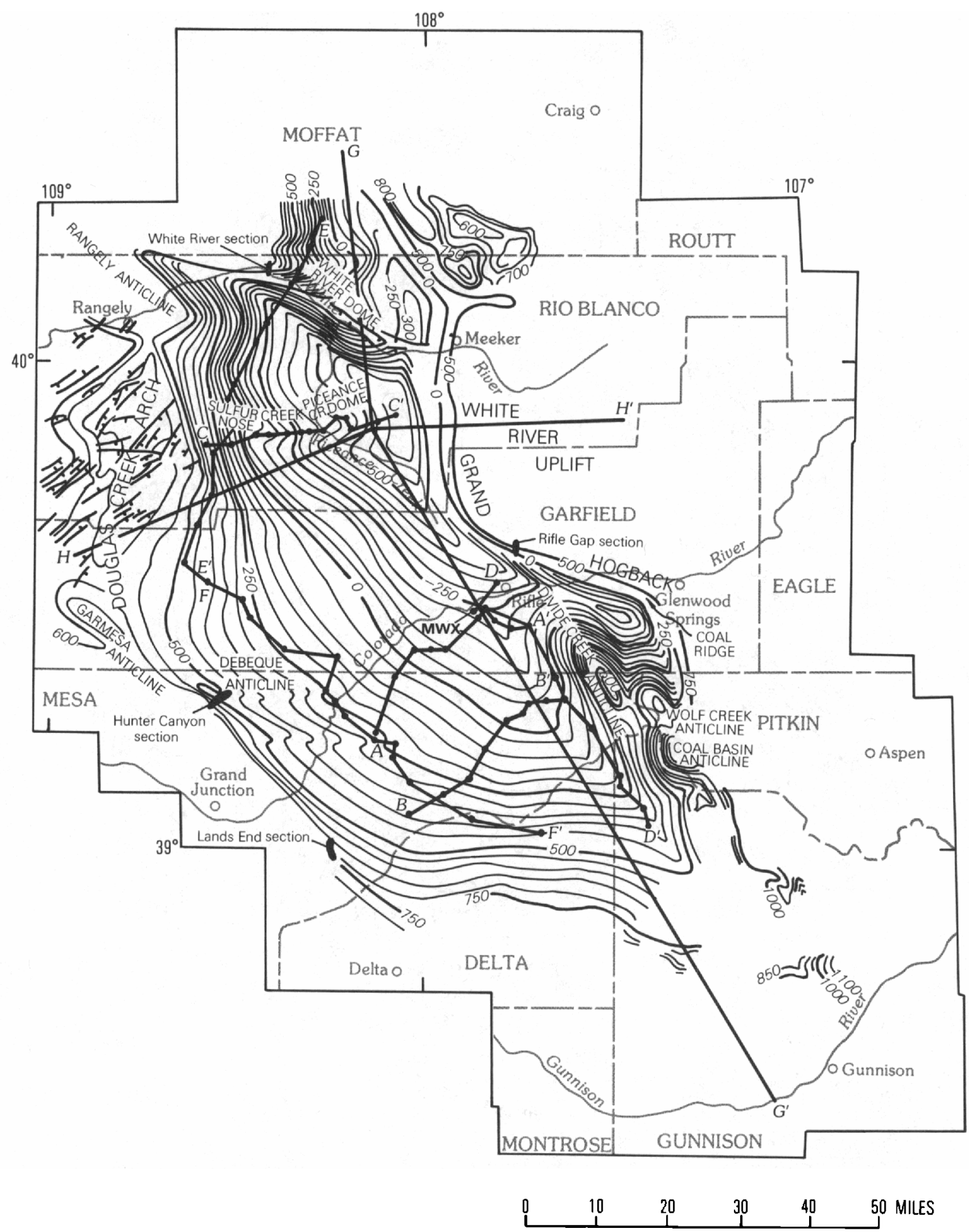

Figure 3. Structure-contour map of top of Rollins Sandstone Member of the Mesaverde Formation and equivalent Trout Creek Sandstone Member of the lles Formation. Contour interval, $500 \mathrm{ft}$; contour values are in tens of feet. Lines of sections (pl. 1) and locations of measured sections (pl. 2) are also shown.

Coal Basin anticlines, are believed to be underlain by deep-seated west- and southwest-thrusting reverse or thrust faults related to the more major thrust fault beneath the Grand Hogback (Gries, 1983); the geometry of the structures may have been later altered by intrusion of plutons during the Oligocene. The Divide Crcek and
Wolf Creek anticlines are the two most productive Mesaverde gas fields in the basin.

Several relatively minor east- and southeasttrending anticlines in the Piceance basin include the Piceance Creek dome-Sulfur Creek nose trend in the central part of the basin, the DeBeque anticline in the 
southwestern part of the basin, and the Garmesa anticline near the southern terminus of the Douglas Creck arch (fig. 3). These anticlines may have formed as a result of reactivation of older faults during the Laramide orogeny, and Laramide movement on these faults was probably mostly strike slip (Stone, 1977).

Research at the MWX site has demonstrated that natural fractures play a critical role in gas production rates. Certain aspects of these fracture systems were studied by Murray (1967), Smith and Whitney (1979), and Dula (1981); more recently, the fracture systems in the Piceance basin have been studied in detail by Verbeek and Grout $(1983,1984 a, b)$ and Grout and Verbcek (1983).

Verbeek and Grout (1984a,b) recognized two basic fracture systems in the basin: the older "hogback system," the dominant system in Mesaverde rocks along the Grand Hogback and possibly in the subsurface in the eastern part of the basin; and the younger "Piceance system," the dominant system in the Tertiary rocks throughout the basin. The older hogback fracture system developed in rocks of the Mesaverde Group prior to uplift along the Grand Hogback and consists of a welldefined fracture set trending N. $80^{\circ} \mathrm{W}$. and a much weaker fracture set trending approximately north. The younger Piceance system consists of several sets of fractures. Throughout much of the basin, a rectangular pair of fracture systems in the Eocene Grecn River Formation trends west-northwest and north-northcast. In some areas, another fracture set trends northnorthwest to north-northeast. Although the westnorthwest system is approximately parallel with the strongly developed N. $80^{\circ} \mathrm{W}$. fracture set in the hogback system, the two sets are of different ages (Verbeek and Grout, 1984a,b).

The west-northwest fracture trend, common to both the hogback and the Piccance fracture systems, is approximately parallel with the dominant fault orientation in the basin. Faulting is not widespread and trends almost exclusively northwest to west-northwest. Several long narrow west-northwest-trending grabens having relatively minor displacement cut the Eocene-age Uinta and Green River Formations in the north-central part of the basin. A northwest-trending graben, having as much as $450 \mathrm{ft}$ of displacement, traverses the crest of the White River dome in the northern part of the basin (fig. 3 ). The trend of this graben becomes easterly near Powell Park, just west of Meeker. A similar northwest to westnorthwest fault trend is in the Uinta basin to the west (Cashion, 1973). In contrast, the majority of faults on the Douglas Creek arch trend northeast; a few trend almost due east. Fault density on the arch is much greater than in either of the adjacent basins. Unfortunately, a comparison between fault and fracture directions cannot be made because the fracture system on the arch has not yet been studied.

Deposition of the Upper Cretaceous Mesaverde Formation or Mesaverde Group in the Piceance basin mostly but not totally predates the Laramide orogeny that created the Piceance basin (fig. 4; pl. 1, views $A-C$ ). The Mesaverde was deposited in the Cretaceous Rocky Mountain foreland basin, a huge basin that covered much of the central part of North America from northern Canada to the Gulf of Mexico (fig. 1). The western boundary of the foreland basin was the Sevier orogenic belt, an area of active uplift and eastward thrusting from Jurassic through early Cenozoic times. Rapid subsidence in the foreland basin during the Cretaceous caused a major marine incursion, and, throughout most of the Cretaceous, an epeiric seaway covered much of the foreland basin including the area of the Piceance basin. Several thousand feet of marine Mancos Shale was deposited in the arca of the Piceance basin during this marine incursion, and the Mancos Shale underlies the Mesaverde throughout the basin. Along the western margin of the seaway, the Sevier orogenic belt was probably the major source of sediments, and transgressions and regressions occurred along a fairly narrow area adjacent to the belt throughout much of the Crctaceous. During Late Cretaccous Campanian time, pulses of clastic sediments, believed to be related to pulses of orogenic activity on the Sevier orogenic belt (Fouch and others, 1983), began to push the shoreline of the epeiric seaway farther and farther to the east. The shoreline transgressed and regressed across the area of the Piceance basin throughout much of the Campanian. By the beginning of Late Cretaceous Maestrichtian time, the shoreline was east of the present-day eastern margin of the basin, and marginal-marine and coastal-plain sediments were being deposited in the Piceance basin. These transgressive and regressive cycles and the overlying marginal-marine and coastal-plain sediments make up the Mesaverde Formation or Mesaverde Group, the principal unit of interest in this report.

The Laramidc orogeny began in Late Cretaceous Campanian time (Tweto, 1975) and overlapped the final phases of thrusting on the Sevicr orogenic belt. Within several areas in the foreland sedimentary basin, the orogeny produced uplift that rearranged drainage patterns, provided local sources of sediment, and eventually partitioned the forcland basin into several much smaller sedimentary basins, including the Piceance basin. During the initial stages of breakup of the foreland basin, much of the area between the rising Laramide uplifts continued to subside and accumulate sediments. At least one Laramide uplift in the study area, the Sawatch uplift southeast of the Piceance basin, began to rise prior to the end of Mesaverde deposition. Before the 

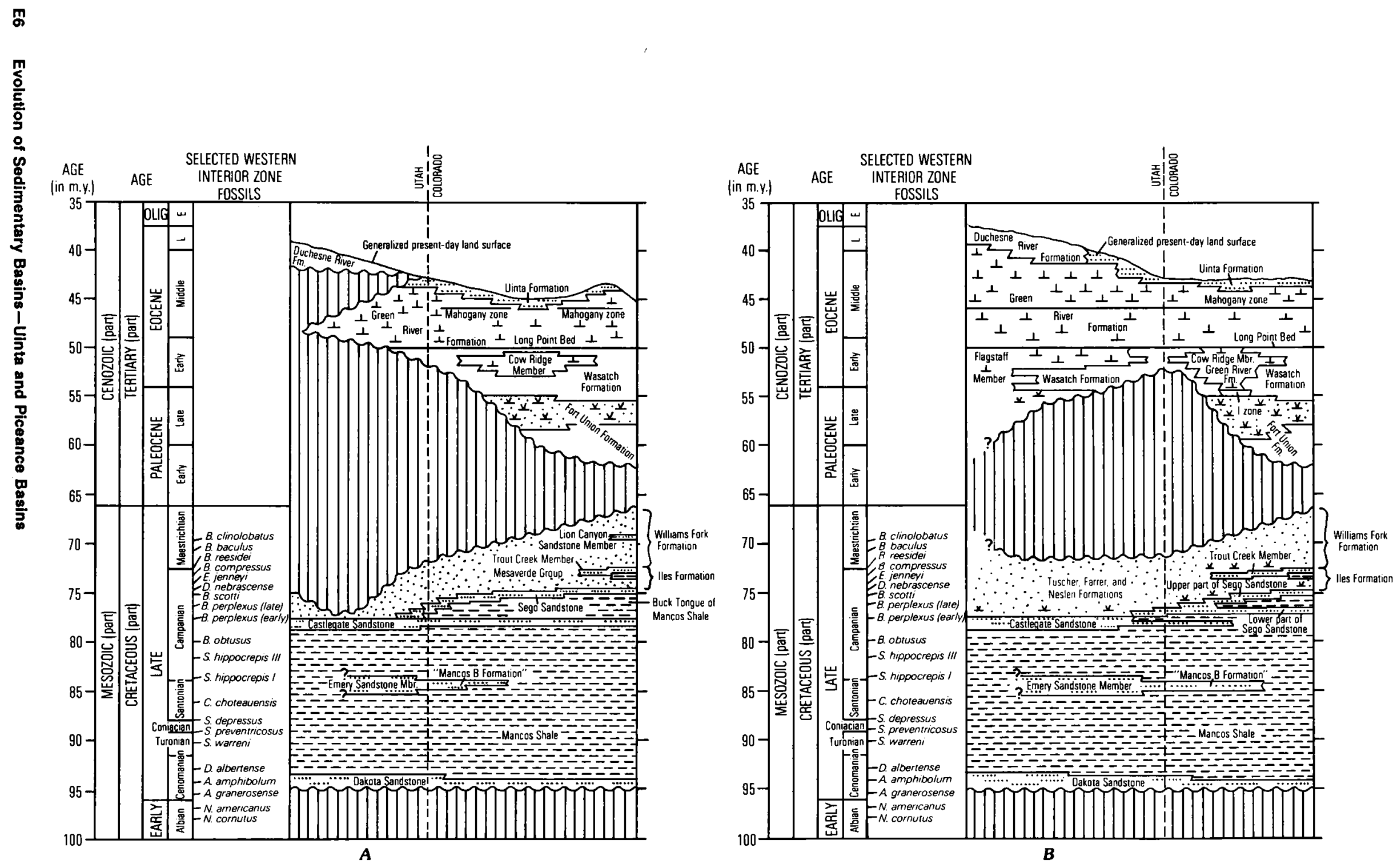


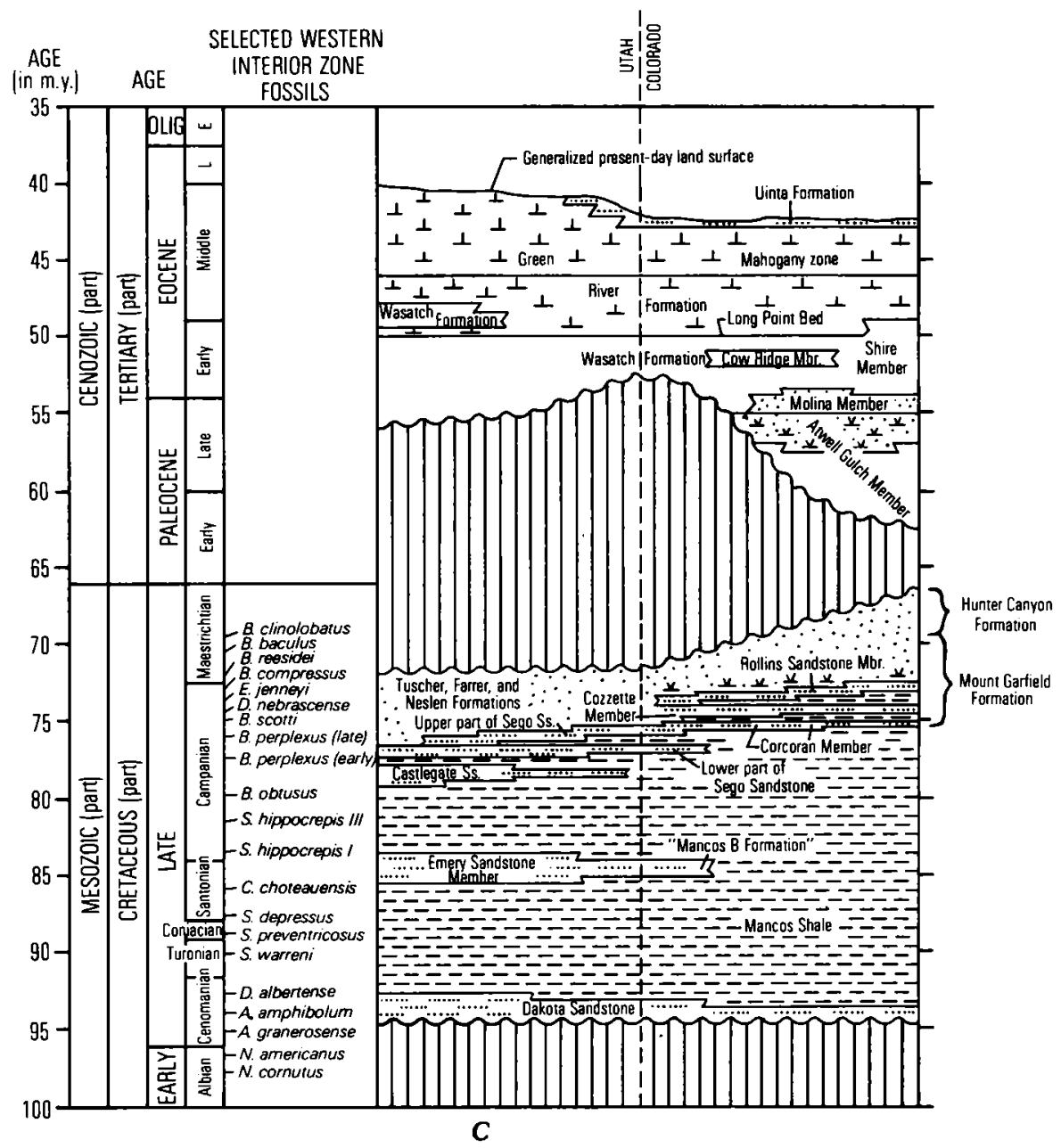

\section{EXPLANATION}

Fluvial, sparse sandstone

Fluvial, abundant sandstone

$\underline{*} \begin{gathered}\text { Paludal, mostly coal and } \\ \text { carbonaceous shale }\end{gathered}$

$\perp \perp$ Lacustrine, carbonate-rich and shale-rich

......... Marine or lacustrine, sand-rich

$==-$ Marine, mostly shale

IIIII Missing strata

Figure 4. Generalized stratigraphic charts of Mesaverde Formation or Group, Piceance basin and eastern Uinta basin. Query (?) indicates boundary uncertain. $A$, Northern Piceance basin and northeastern Uinta basin. $B$, Central Piceance basin and east-central Uinta basin. $C$, Southern Piceance basin and southeastern Uinta basin. Fossil genera: $B, B a c u l i t e s ; E$, Exiteloceras; $D$. nebrascense, Didymoceras; S, Scaphites; $C$, Clioscaphites; $D$. albentense, Dunveganoceras; $A, A$ canthoceras; $N$, Neogastroplites. 
end of the Cretaceous, a major period of regional uplift affected not only the rising Laramide uplifts but also the basin areas, including the Piceance basin. The unconformity produced by this regional event separates the Mesaverde Formation or Group from the younger lower Cenozoic rocks throughout the basin. Basin subsidence began again during the Paleocene, and, before subsidence ended near the end of the Eocene, as much as $12,000 \mathrm{ft}$ of Paleocene and Eocene sediments was deposited in the deepest part of the basin, west of the Grand Hogback. This thick unit of lower Cenozoic rocks provided the thermal blanket that led to the generation of large quantities of methane by source rocks in the Mesaverde.

To summarize, the three most important events in the development of the Mesaverde low-permeability gas deposit in the Piceance basin are: (1) development of the original depositional patterns, which were controlled by a combination of pulses of sediments from the Sevier orogenic belt and the rise of local Laramide uplifts that rearranged drainage patterns and produced new sediment sources; (2) regional beveling, which began before the end of the Cretaceous and lasted until sometime during the Paleocene; and (3) burial of the Mesaverde Group rocks beneath a thick blanket of lower Cenozoic rocks.

\section{MESAVERDE STRATIGRAPHY AND GENERAL ENVIRONMENTS OF DEPOSITION}

Detailed measured surface sections of the Mesaverde Formation or Group from four areas of the basin were used in this study to aid in understanding the stratigraphy of the Mesaverde and to provide critical data for the interpretation of reservoir characteristics and gas source beds (fig. 3 , pl. 2). The sections show lithology, grain size, and internal features such as bedding type and identified fossils. Two sections have been previously published, the Hunter Canyon section from the western margin of the basin (Johnson and others, 1980) and the Rifle Gap section from the eastern margin of the basin (Johnson, 1982), and two are new to this report, the Lands End section from the southwestern margin of the basin and the White River section from the northern margin of the basin.

\section{Marine Transgressions and Regressions}

An understanding of the geometry of marine and nonmarine sandstone reservoirs is necded in order to better model gas production data and optimize the size of hydraulic fracture treatments. Several transgressive and regressive cycles are in the lower part of the Mesaverde (figs. 4-6). They are Late Cretaceous Campanian in age and apparently were produced by pulses of sediments from the Sevier orogenic belt to the west (Fouch and others, 1983). The scaward limits of these cycles (figs. 5, 6) are modified from Zapp and Cobban (1960), Warner (1964), Gill and Cobban (1969), and Gill and Hail (1975). Regressive cycles (from oldest to youngest) are represented by the:

1. Morapos Sandstone Member of the Mancos Shale

2. Castlegate Sandstone

3. Loyd Sandstone Member of the Mancos Shale

4. Lower part of the Sego Sandstone

5. Upper part of the Sego Sandstone and the Corcoran Member of the Mesaverde or Mount Garfield Formation

6. Cozzette Member of the Mesaverde or Mount Garficld Formation

7. Rollins Sandstone Mcmber of the Mesaverde Formation and the Trout Creek Sandstone Member of the Iles Formation

8. Regressive sandstones informally named the middle and upper sandstones by Collins (1976)

9. Lion Canyon Sandstone Member of the Williams Fork Formation (fig. 5)

The middle and upper sandstones of Collins (1976) and the Lion Canyon Sandstone Member are only in the easternmost part of the basin. Scattered evidence for younger marine rocks in the Mesaverde is along the Grand Hogback (Lorenz, 1982).

The maximum seaward limit of each regression shown on figure 5 is where the regressive cycle is represented by less than 10-15 $\mathrm{ft}$ of nearly continuous sandstone. Although this is not the exact position of maximum shoreline regression, it is the approximate limit of reservoir potential. The thin sandstones found near the seaward limit of each regressive cycle are almost certainly shclf sandstones that were deposited seaward of the line of maximum shoreline regression. The exact position of maximum shoreline regression for each cycle probably can never be accurately positioned because of reworking of sediments during the subsequent transgression. Each regressive cycle shown on figure 5 is separated from the overlying regressive cycle by a transgressive tongue of marine Mancos Shale.

The nomenclature applied to these regressive cycles is complex and in many instances inconsistent. In some cases, such as the Corcoran and Cozzette Mcmbers, the names are applied to the entire sequence of rocks between tongues of marine Mancos Shale; in other instances, such as the Sego Sandstone and Rollins and Trout Creek Sandstone Members, the names are applied only to the basal regressive sandstone. 

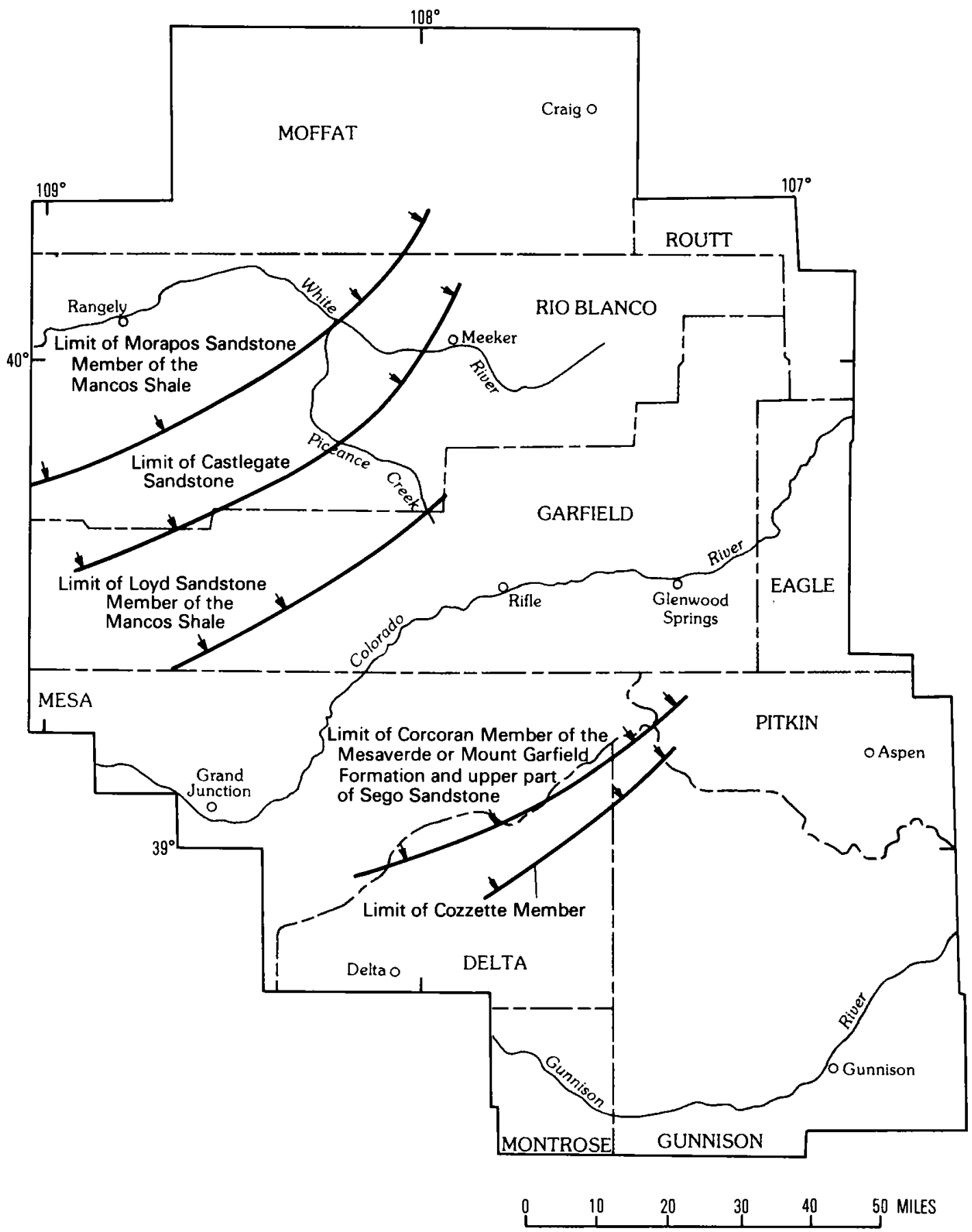

Figure 5. Limits of Mesaverde regressive cycles . Limits of lower part of Sego Sandstone cycle cannot be determined with certainty. Seaward limit of Rollins-Trout Creek cycle is beyond southeastern corner of basin and map area. Limits of cycles represented by the middle and upper sandstones of Collins (1979) and the Lion Canyon Sandstone Member of the Williams Fork Formation are only in the easternmost part of the Piceance basin and are not shown. Arrows indicate direction of regression. Modified from Zapp and Cobban (1960), Warner (1964), Gill and Cobban (1969), and Gill and Hail (1975).

The nature of the regressive cycles is also highly variable. Some regressive cycles, such as the one represented by the Rollins and Trout Creek Sandstone Members, consist of a single, regionally persistent, upward-coarsening beach sandstone that is overlain by a very coaly lower-coastal-plain or deltaic deposit. Other cycles, such as those represented by the lower part of the Sego and the upper part of the Sego and the Corcoran, 

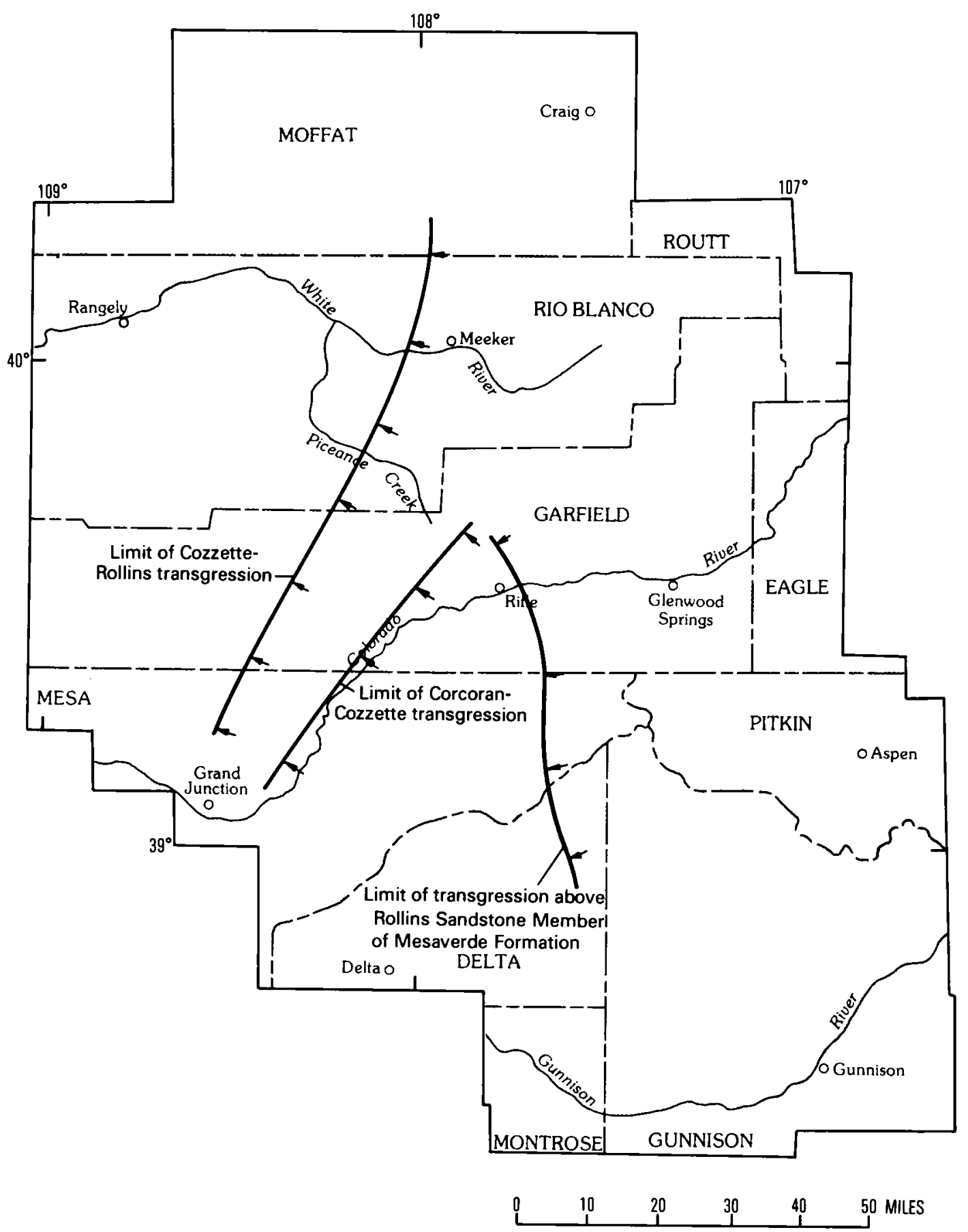

Figure 6. Limits of Mancos transgressive shale tongues. Arrows indicate direction of transgression. Modified from Zapp and Cobban (1960), Warner (1964), Gill and Cobban (1969), and Gill and Hail (1975).

are highly complex and consist of scveral less regionally persistent marginal-marine sandstones and much less coaly lower-coastal-plain deposits.

The regressive cycles grade upward into monotonous fluvial sequences consisting of point-bar and overbank deposits. The lenticular channel sandstones in the regressive cycles generally are thinner and less laterally persistent than channel sandstones in the fluvial sequences above the regressive cycles. The thinner channel sandstones in the regressive sequences probably were deposited by distributary channels and small local channels that drained limited areas of the lower coastal plain, whereas the thicker channel sandstones in the overlying fluvial sequences probably were deposited by much larger channel systems landward of the area of distributary channel development. 
In general, the scaward limit of each succeedingly younger regressive cycle extends farther toward the southeastern corner of the basin, a movement that reflects the gradual infilling of the Cretaceous seaway during Late Cretaceous time (figs. 4, 5). The seaward limits of the Rollins-Trout Creek cycle and the upper unnamed regressive cycle extend bcyond the southeastern corner of the basin and hence are not shown on figure 5. Three cross sections were constructed to analyze correlations, facies, and reservoir trends in these cycles (pl. 1, views $D-F$ ). The sections are approximately perpendicular to the paleoshoreline, that is, parallel with the direction of most rapid facies changes. Generalized environments of deposition and productive and nonproductive intervals are shown, as are several laterally persistent gamma-ray markers in the tongues of marine shale. Many of these markers are probably bentonite-rich beds that formed from alteration of volcanic ash, and they probably represent approximate time lines.

The oldest regressive cycle is the Morapos Sandstone Member of the Mancos Shale in the northwestern corner of the basin (fig. 5; pl. 1, view $E$ ). The Morapos Sandstone Member was originally applied by Hancock (1925) to a zone of thinly bedded sandstone, 15-30 ft thick, exposed along Morapos Creek about 25 mi northeast of Meeker and northeast of the Piceance basin. It has also been mapped in the northern part of the Piceance basin (Izett and others, 1985) and probably correlates with the "B" sandstone of Dyni (1968) and Hail (1974). The Morapos Member was deposited during the Baculites maclearni zone. It is along the line of section $E-E^{\prime}$ (pl. 1), where it consists of a single sandstone $20-50 \mathrm{ft}$ thick. Toward the southeast, the Morapos grades into a very persistent silty zone in the Mancos Shale that can be traced about $25 \mathrm{mi}$ beyond the seaward limit of the Morapos as shown on figure 5.

The next youngest regressive cycle in the basin is the Castlegate Sandstone in the western and northwestern parts of the basin. The seaward limit of the Castlegate extends 10-15 mi farther southeast than does the seaward limit of the older Morapos Member (fig. 5; pl. 1, view $E$ ). The name Castlegate Sandstone was applied by Forrester (1918), Spieker and Reeside (1925), and Clark (1928) to a prominent cliff-forming sandstone sequence of Late Cretaceous age that locally forms a topographic feature called the Castle Gate in Price Canyon, about $10 \mathrm{mi}$ northwest of the town of Price, Utah. The Castlegate was made a member of the Price River Formation by Spieker and Reeside (1925) and was later elevated to formation rank by Fisher and others (1960). The unit was traced by Fisher (1936) along its outcrop on the Book Cliffs to within $2 \mathrm{mi}$ of the UtahColorado State line, near the western boundary of the Piceance basin, where it grades into Mancos Shale. It also has been traced along the northwestern margin of the Piceance basin (Cullins, 1968; Gill and Hail, 1975). A structure-contour map of the top of the Castlegate and a cross section showing lateral changes in the Castlegate were recently compiled for the Uinta and Piceance basins (Johnson, 1986).

Fouch and others (1983) believed that the upper part of the Castlegate in Price Canyon includes beds that are lithologically and temporally equivalent to the Bluecastle Sandstone Member of the Neslen Formation of the Uinta basin, and they redefined the Bluecastle as a tongue of the Castlegate. They believed that, in an easterly direction, the Castlegate splits into two units, the "Bluecastle Tongue" of the Castlegate and what has traditionally been called the Castlegate Sandstone in the eastern part of the Uinta basin and in the Piceance basin. Fortunately, this possible nomenclature problem is confined to the western part of the Uinta basin and does not affect interpretations of the Castlegate Sandstone in the Piceance basin.

In the Uinta basin, the Castlegate represents a highly complex system of fluvial and deltaic environments. In the Piceance basin, the Castlegate is near its seaward limit and is composed of a single, persistent, blanketlike sandstone. This sandstone ranges from as thick as $100 \mathrm{ft}$ in the Rangely area (Gill and Hail, 1975) to a wedge-shaped edge near the southeastern seaward limit of the Castlegate. Similar to the older Morapos Member of the Mancos Shale, the Castlegate grades seaward into a silty zone in the Mancos Shale that extends $25-45 \mathrm{mi}$ beyond the seaward limit of the Castlegate as shown on figure 5. The Castlegate Sandstone and the thin silty zone probably are approximately synchronous stratigraphic units because they do not appear to change stratigraphic position with respect to a very conspicuous, high gamma-ray log kick located 150-225 ft below their tops. Fouch and others (1983) suggested that the type Castlegate in Price Canyon spans the ammonite zones from Baculites asperformis to Exiteloceras jennyi; however, the much thinner, blanketlike Castlegate of the eastern Uinta basin and western Piceance basin probably was deposited only during the Baculites perplexus interval (Gill and Hail, 1975).

The lateral persistence of the Morapos Member of the Mancos, the Castlegate Sandstone, and their silty seaward equivalents is remarkable and cannot be fully explained at this time. In the Rangely area, the Castlegate Sandstone is described by Cullins (1969) as fine grained and massive, interbedded with siltstone and shale, and capped locally by a thin coal. The similarity between the Castlegate and many thin, transgressive sandstones suggests that sand deposited during the Castlegate regression may have been reworked and smeared out over a broad area of the continental shelf during the subsequent transgression. The Corcoran and Cozzette 
Sandstone Members described below also grade into similar thin, blanketlike sandstones near their seaward limit in the southeastern part of the basin.

The Buck Tongue of the Mancos is stratigraphically between the Castlegate Sandstone and the overlying Sego Sandstone (pl. 1, vicw E) (Erdmann, 1934). It ranges in thickness from about $100 \mathrm{ft}$ near Rangely (Gill and Hail, 1975) to $300-400 \mathrm{ft}$ near the seaward pinchout of the Castlegate. The transgression represented by the base of the Buck Tongue probably occurred rapidly. Baculites perplexus has been collected from several localities of the Buck Tongue (Gill and Hail, 1975). Bccause the Buck Tongue of the Mancos extends west of the Colorado-Utah State line, its landward pinchout is not shown on figure 6 .

A regressive cycle, represented by the Loyd Sandstone Member of the Mancos Shale, occurs within the Buck Tongue. The Loyd Sandstone Member was originally named and described by Konish (1959) for exposures on the south end of Iles Mountain, northeast of the Piceance basin, and was traced along the northern margin of the Piceance by Gill and Hail (1975). It can be easily traced in the subsurface throughout the northwestern part of the basin (pl. 1, vicw $E$ ), and its seaward pinchout is shown on figure 5. The Loyd Sandstone Member was not measured and described in the present study but has been described by Konish as a fine- to very fine grained, very calcareous and fossiliferous sandstone. Konish described the Loyd as a key marker bed, a description consistent with its occurrence in the subsurface where it is a relatively thin, persistent marker horizon that seems to occur in about the same stratigraphic position throughout most of its extent in the basin. Baculites perplexus has been collected from the Loyd Sandstone Member (Gill and Hail, 1975).

The next younger regressive cycle is represented by the lower part of the Sego Sandstone. The Sego was originally named for the town of Sego, Utah, by Erdmann (1934). Fisher (1936) traced the Sego castward along the Book Cliffs to the Colorado-Utah State line. Eastward from the State line, the Sego was mapped along the Book Cliffs by Erdmann (1934), who found that the Sego was split into an upper and lower tongue near the State line by a tongue of Mancos Shale that he named the Anchor Mine Tongue. The seaward limit of the lower part of the Sego is shown on view $F$ (pl. 1); however, because the lower part of the Sego Sandstone could not be identificd with certainty in the subsurface farther to the east and north, its seaward pinchout is not shown on figure 5 . The lower part of the Sego was not measured at any of the four detailed measured section localities.

The next youngest regressive cycle is represented by the upper part of the Sego Sandstone and the Corcoran Member of the Mesaverde or Mount Garfield Formation. The upper part of the Sego refers to the basal regressive sandstone of this regressive cycle in the area where the Anchor Mine is stratigraphically the highest tongue of Mancos in the section. In the southeastern half of the Piceance basin, where a higher marine tongue is present, the name Corcoran Member is generally applied to the entire sequence between the Anchor Mine Tongue and this next higher tongue of Mancos. This higher tongue of Mancos is labeled the Corcoran-Cozzette transgression (fig. 6). The Corcoran Member and the next youngest regressive cycle, the Cozzette Member, were originally described and named by Young (1955), who defined the two units as members of the Price River Formation. The name Price River Formation was originally used in the Uinta basin in Utah but was extended by Young (1955) into Colorado. Erdmann (1934) had previously assigned the name Mount Garfield Formation to approximately the same sequence of rocks, and the name Price River Formation is not widely used in Colorado. The names Corcoran and Cozzette have become firmly entrenched, however, and the units are now generally regarded as members of the Mount Garfield Formation and locally of the Mesaverde Formation (Gill and Hail, 1975; Johnson and others, 1980). The upper and lower parts of the Sego Sandstone and the Corcoran Member were deposited during the Baculites scotti and Didymoceras nebrascense ammonite zones (Gill and Cobban, 1969; Gill and Hail, 1975).

The Hunter Canyon section (pl. 2) is seaward of the pinchout of the lower part of the Sego Sandstone and very close to the landward pinchout of the tongue of Mancos Shale deposited during the Corcoran-Cozzette transgression. Although some workers have traced the tongue of Mancos Shale deposited during the CorcoranCozzette transgression into a thin silty zone at Hunter Canyon (Gill and Hail, 1975), this zone could not be identified with certainty by the present author. Because Hunter Canyon is so close to the landward pinchout of this tongue of Mancos Shale, there is an overlap in the nomcnclature used. The name "upper part of the Sego Sandstone" refers to the basal regressive sandstone of this regressive cycle, whereas the name "Corcoran Member" refers to the remainder of the sequence. At Hunter Canyon, the upper part of the Sego consists of a 75-foot-thick, upward-coarsening, shoreface sandstone that has low-angle cross laminations near its base, horizontal laminations near the middle, and low-angle cross laminations and trough cross laminations near the top. The sandstone has been extensively burrowed by marine organisms. It is overlain by a coal bed $1 \mathrm{ft}$ thick that is in turn overlain by $12 \mathrm{ft}$ of gray shale. The Corcoran directly overlies this thin shale layer.

Farther to the southeast along the Book Cliffs, at the Lands End section (pl. 2), the upper Sego-Corcoran regressive cycle is near its seaward pinchout and consists of an 80- to 85-foot-thick section of interbedded 
sandstone containing ripple and low-angle cross laminations and gray shale. The sequence is probably a shelf deposit that formed seaward of the maximum shoreline regression during this regressive cycle. At Lands End, the name Corcoran Member is applied to the entire sequence.

At the White River section (pl. 2), the Sego Sandstone is directly overlain by the Iles Formation and is considered the Sego Sandstone Member of the Iles Formation by Collins (1976). In the present rcport, the Sego Sandstone is considered a separate formation. At the White River section, the Sego Sandstone is approximately $50 \mathrm{ft}$ thick, has low-angle and trough crossbedding, and is probably a shoreface sandstonc. It is overlain by $450 \mathrm{ft}$ of deltaic sediments including meandering distributary channels as thick as $35 \mathrm{ft}$, carbonaceous shale, and one thin coal bed. Environments of deposition of the Sego have been studied in detail in this area by Noe (1983), who recognized tidal flat, lagoonal, tidal inlet, and shoreface sandstone facies.

The Rifle Gap section (pl. 2) is near the landward pinchout of the tongue of Mancos Shale deposited during the Corcoran-Cozzette transgression (figs. 5, 6). Because this tongue of Mancos could not be identificd with certainty by the author, the Corcoran and Cozzette Members were combined into one unit. At Rifle Gap, the combined Corcoran and Cozzette contain a diverse assemblage of rocks including oyster-bearing sequences that were probably deposited in brackish-water lagoons, marshes, tidal flats and tidal channels, and coaly sequences of lower-delta-plain or coastal-plain origin. Lenticular channel sandstones containing large-scale lateral accretion units are also in the section and were deposited by lower-coastal-plain or delta-plain distributary channels. Shoreface sandstones containing low-angle and trough cross laminations are also in the Corcoran and Cozzette at Rifle Gap.

The next youngest regressive cycle is represented by the Cozzette Member of the Mount Garficld or Mesaverde Formation and is recognized throughout most of the southern half of the Piceance basin (fig. 5). The Cozzette Member was deposited during the Didymoceras stevensoni ammonite zone (Zapp and Cobban, 1960; Gill and Hail, 1975).

The four surface measured sections (pl. 2) show the highly variable nature of the Cozzette Member. The Hunter Canyon section is near the landward pinchout of both shale tongues of the Mancos that separate the Cozzette from the overlying and underlying units, and the Cozzette has rarely been traced much farther west. The Cozzette Member consists of several sandstones that are as thick as $90 \mathrm{ft}$ and interbedded with thin gray shale. The sandstones have been extensively burrowed, contain lowangle and trough cross laminations, and probably were deposited in a shoreface environment. One probable channel sandstone contains drift-ripple laminations. No oyster beds were found.

The White River section is considerably landward of the confining tongues of Mancos Shale that define the Cozzette, and the unit was not mapped. At Lands End, the Cozzette is near its seaward limit and consists of a 60to 70-foot-thick interval of interbedded sandstone and gray shale containing horizontal to low-angle cross laminations. At Lands End, the Cozzette is probably a shelf sand deposited somewhat seaward of maximum shoreline regression.

The seaward pinchouts of both the Sego-Corcoran regressive cycle and the Cozzette regressive cycle vary markedly between the southeastern and southwestern parts of the basin, a variation that cannot be explained at this time. In the southwestern part of the basin, the two cycles grade relatively abruptly into the adjacent Mancos Shale (pl. 1, view $F$ ). In the southeastern part (pl. 1, view $D)$, the two cycles grade first into very persistent blanket sandstones and then into silty zones in the Mancos Shale that can be traced for a considerable distance beyond the limits of regression shown on figure 5. The lateral equivalent of the Sego-Corcoran regression in the Mancos Shale does not appear to change stratigraphic position with respect to a persistent gamma-ray marker (pl. 1, view $D$ ), a relationship that suggests this zone closely approximates a synchronous stratigraphic unit.

The gamma-ray data indicate that the transgressions that ended both the upper Sego-Corcoran and the Cozzette regressive cycles occurred rapidly. The first gamma-ray marker above the top of the Cozzette does not noticeably change stratigraphic position across the entire length of the section (pl. 1, view $F$ ). The marine shales deposited during these transgressions cover about the same area of the basin; the marine shale above the younger Cozzette is oriented slightly more toward the north than is the older marine shale above the Corcoran (fig. 6).

The Rollins and Trout Creek Sandstone Members represent the next youngest and most laterally extensive regressive cycle in the Piceance basin (pl. 1, views $D, F$ ). This cycle is present in all but the northwestern corner of the basin, where it grades into nonmarine sediments (Johnson, 1983). The Rollins and Trout Creek were originally mapped as two separate units but later shown to be equivalent (Warner, 1964). The Trout Creek was originally named and mapped in the Sand Wash basin north of the Piceance basin by Fenneman and Gale (1906) and was traced into the northeastern part of the Piceance basin by Hancock and Eby (1930). The Rollins was named and mapped extensively by Lee (1912), who traced the prominent sandstone around much of the southern margin of the Piceance basin. Warner (1964) traced the Rollins in the subsurface from the Book Cliffs 
in the southwestern Piceance basin to the Grand Hogback near Newcastle. He then followed outcrops of the Rollins north along the Grand Hogback to the Meeker area, where they correlate with the Trout Creek. In the northeastern corner of the basin and in the Sand Wash basin to the north, the upper contact of the Trout Creek Member is defined as the boundary between the Iles Formation and the overlying Williams Fork Formation (Hancock and Eby, 1930). The only reported occurrence of baculites associated with the Rollins or Trout Creek is at Oak Creek, north of the Piceance basin, where $\mathrm{BaCu}$ lites reesidei was collected above the Trout Creek in the Williams Fork Formation (Zapp and Cobban, 1969).

The Rollins and Trout Creek Sandstone Members represent a much simpler regressive cycle than any of the older cycles previously discussed. Throughout most of the Piceance basin, the cycle consists of a single, upwardcoarsening sequence capped by a beach sandstone. Of the four measured sections presented in this report, the cycle is best developed in the Rifle Gap section (pl. 2), where three zones are present: the transition zone between offshore and shoreface, the lower shoreface zone, and the combined upper shoreface and foreshore zone. The transition zone consists of interbedded shale and lenticular sandstone units. Sandstone units increase in both abundance and thickness toward the top of the zone and generally have sharp bases, though both sharp and gradational tops were observed. Many tops have bcen extensively burrowed. Internally the sandstones contain flaser bedding, parallel-horizontal laminations, and low-angle, hummocky and trough crossbedding. The lower shoreface zone consists mostly of low-angle and trough crossbedded sandstone. The upper shoreface and foreshore zone consists mostly of low-angle crossbedded sandstone.

At Lands End (pl. 2), the transition zone is thin and not well developed and the combined upper shoreface and foreshore zone is mostly missing, possibly because it was truncated during the transgression that followed. At Hunter Canyon (pl. 2), both the transition zone and the combined upper shoreface and foreshore zones also are poorly defined. The shale between the Rollins and the underlying Cozzette has pinched out and the lower shoreface zone of the Rollins is directly on top of the Cozzette. The White River section (pl. 2) is more than 20 $\mathrm{mi}$ landward of the pinchout of the marine shale between the Trout Creek and the underlying Cozzette, and the Trout Creek has graded into nonmarine rocks. A discontinuous sandstone believed to be equivalent to the Trout Creek has been locally mapped in this area (Hail, 1974). It is at the base of a major coal zone that has been traced to the south into the Cameo-Fairfield coal zone (Nuccio and Johnson, 1983), the widespread coal zone above the true marine Rollins and Trout Creek Members. In the White River section, the Trout Creek equivalent is a discontinuous fluvial channel sandstone about $25 \mathrm{ft}$ thick that has parallel-horizontal and trough crossbedding. The overlying coaly sequence is $220 \mathrm{ft}$ thick. As previously mentioned, the top of the Trout Creek in this area is defined as the top of the Iles Formation. Wherever the Trout Creek equivalent is absent, the base of the coaly zone is mapped as the contact between the Iles and the overlying Williams Fork Formations (Hail, 1974). The Rollins-Trout Creek cycle climbs $300 \mathrm{ft}$ or more stratigraphically with respect to key gamma-ray kicks, toward its seaward limit (pl. 1, views $D$, $F$ ), and this rise suggests that the Rollins-Trout Creek regression occurred more slowly than earlier regressions.

Throughout the Piceance basin, the CameoFairfield or equivalent coal zone directly overlies the Rollins or Trout Creek Members. The name Cameo coal zone was originally applied by Erdmann (1934) to the lowermost coal seam above the Rollins Member in the southwestern part of the basin. Erdmann applied the name Carbonera coal zone to higher seams in the coaly interval above the Rollins. The name Fairfield coal group was originally applied by Hancock and Eby (1930) to the entire coaly sequence above the Trout Creek Member in the northeastern corner of the basin. In this report, the name Cameo-Fairfield coal zone refers to the entire coaly interval above the Rollins and Trout Creck Sandstone Members. The Cameo-Fairfield coal-bearing zone is as thick as a thousand feet and contains the most economically important and most extensively mined coals in the Piccance basin. It is also probably the most important source for gas in Mesaverde rocks, and an estimate of the amount of gas generated by this zone is presented later in this report. The total thickness of coal in this sequence ranges from near zero in the extreme southeastern part of the basin to greater than $180 \mathrm{ft}$ in the northeastern corner of the basin. Throughout most of the basin, however, the total thickness of coal in this zone is 20-80 ft (fig. 7). This thickness compares with a maximum of $18 \mathrm{ft}$ of coal as measured in the combined upper Sego-Corcoran and Cozzette regressive cycles. In the southeastern part of the basin, the Cameo-Fairfield coal zone as used in this report includes coals associated with the next younger regressive cycle, which will be described later in this report. In a limited area of this part of the basin, these upper coals are separated from the lower part of the Cameo-Fairfield by a thin tongue of marine shale and regressive marine sandstone. Northwest of the pinchout of these marine units, the upper coals merge with coals of the lower part of the Cameo-Fairfield coal zone and cannot be distinguished from them.

Typically, no transition zone intervenes between the beach cycle of the Rollins or Trout Creek and the overlying Cameo-Fairfield coal zone, and a coal bed directly overlies the beach sandstone. Individual coal 


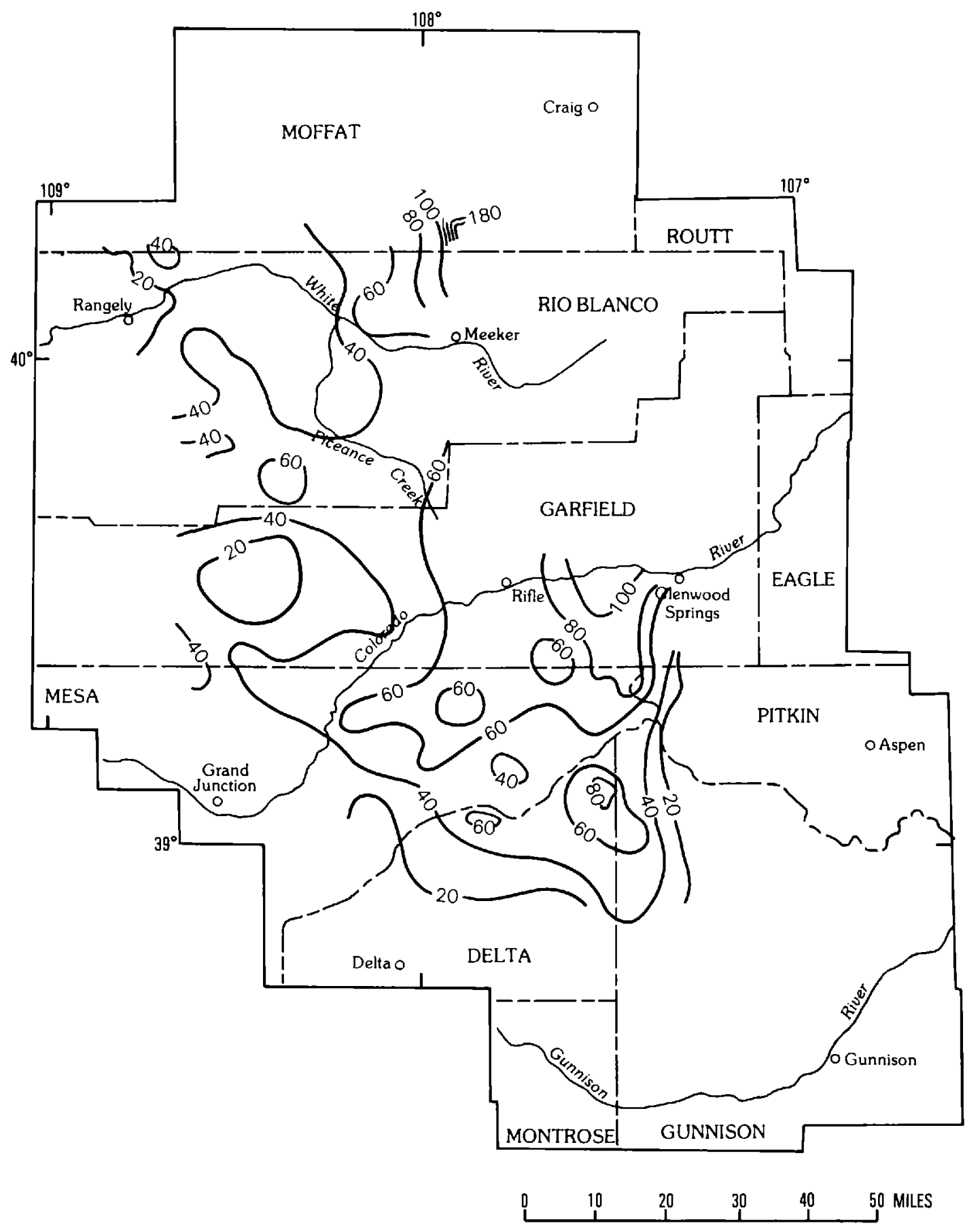

Figure 7. Total coal thickness in Cameo-Fairfield coal zone. Contour interval $20 \mathrm{ft}$.

beds in the Cameo-Fairfield zone are shown on plate 1 (views $D-F$ ) to give an idea of the coal-bed frequency and distribution, but individual coal seams cannot be correlated for any great distance. Collins (1976, p. 25) described a 35-foot-thick coal seam in the coal basin area that splits into four scams $3,6,8$, and $10 \mathrm{ft}$ thick within a distance of less than half a mile. This rapid change from one or two thick seams to several much thinner seams was also frequently observed by the author in drill-hole cuttings.
In the southeastern part of the basin, the CameoFairfield coal zone is overlain by marine shale and thins to the southeast (pl. 1, view $D$ ). The amount of thinning is approximately equal to the amount the underlying Rollins or Trout Creek Member climbs stratigraphically. The Cameo-Fairfield coal zone may once have thinned to a wedge-shaped edge along the line of seaward pinchout of the Rollins or Trout Creek, southeast of the presentday limit of Mesaverde outcrops in the basin; and, similar to other transgressions described in the basin, the 


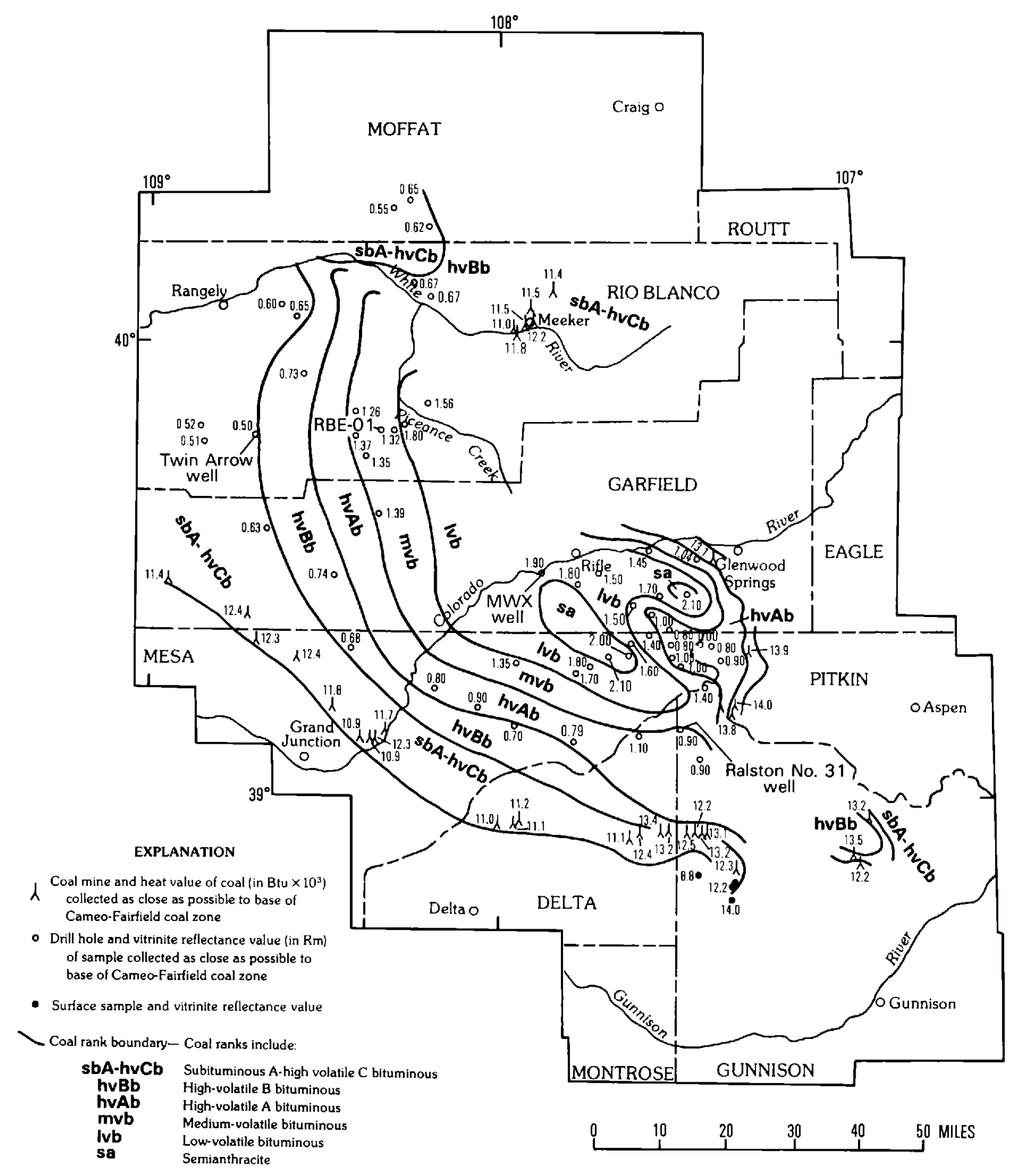

Figure 8. Coal rank near base of Cameo-Fairfield coal zone. From Freeman (1979) and Nuccio and Johnson (1983).

transgression that followed the Rollins-Trout Creek regression probably occurred rapidly.

The Cameo-Fairfield coal zone contains predominantly low sulfur coals that were probably deposited under freshwater conditions (Collins, 1976). Brackish-water fossils have been reported locally from this coal zone in the southern part of the basin, where the coal zone is relatively thin and overlain by marine shale
(Lee, 1912; Collins, 1976). Collins (1976) reported highsulfur coals of probable brackish-water origin in the Middle Thompson Creek area along the southeastern margin of the basin. Coal ranks near the base of the Cameo-Fairficld coal zone vary from subbituminous $A$ and high-volatile $\mathrm{C}(\mathrm{sbA}-\mathrm{hvCb})$ around the western and southwestern margins of the basin to semianthracite (sa) along the structural trough of the basin (fig. 8). 
Channel sandstones are interbedded with the coal beds and carbonaceous shale in the Cameo-Fairficld coal zone. These sandstones contain parallel-horizontal, trough cross, and drift-ripple laminations and display large-scale lateral accretion. They were probably deposited by streams having a medium to high sinuosity. At the Hunter Canyon and Lands End measured sections (pl. 2), these channel sandstones are 10-20 $\mathrm{ft}$ thick and make up 10-15 percent of the section; at Rifle Gap (pl. 2), channel sandstones as thick as $30 \mathrm{ft}$ make up more than 50 percent of the section. Several significant coal beds are at Rifle Gap, despite the large number of stream channels. These coal beds have been largely clinkered by natural coal fires near outcrop.

The origin of these channel deposits is problematical but is directly related to the origin of both the Rollins and Trout Creek Sandstone Members and the Cameo-Fairfield coal zone. The sandstones may have been deposited predominantly by distributary channels from large river systems, such as those believed to have been present during the upper Sego-Corcoran and the Cozzette regressions (Lorenz, 1984), or they may have been deposited predominantly by much smaller local stream systems that originated on the adjacent coastal plain. The first possibility suggests that the Rollins-Trout Creek regression in the Piceance basin is a deltaic regression somewhat similar to the upper Sego-Corcoran and the Cozzette regressions except that sediments in the Rollins and Trout Creek were much more reworked by longshore currents. The second possibility suggests that the major delta system or systems that supplied scdiments to the Rollins-Trout Creek regression were either north or south of the Piceance basin and thus the Rollins-Trout Creek cycle in the Piceance basin was a strand-plain regression between major delta lobes.

The Rollins-Trout Creek shoreline is east of the Piceance basin and could not be shown on figure 5; however, the maximum landward extent of the regression that followed deposition of the Rollins-Trout Creek trends almost due north, in contrast to earlier transgression and regressions that trend northeast. This north trend suggests that the Rollins-Trout Creek shoreline may also trend north, a direction perhaps more favorable to sediment reworking by longshore currents. The greater amount of reworking in the Rollins-Trout Creek may have resulted, however, from the slowcr rate of regression, which would have allowed more time for sediment reworking by longshore currents. In eit her case, the slower rate of regression during deposition of the Rollins and Trout Creek Sandstone Members, as compared to rates of regression during deposition of earlier regressive cycles, may explain the greater abundance of coals associated with the Rollins and Trout Creek. A slow regression rate implies a near balance between subsidence and sedimentation, a condition favorable to thick coal accumulation (Balsley, 1982). A more regional study of the Rollins and Trout Creek Sandstone Members including the Sand Wash basin to the north is required to determine if channel sandstones in the Cameo-Fairfield coal zone were deposited by distributary channcls from major river systems (Lorenz, 1984 ) or by small coastal river channels.

Two younger regressive marine cycles are in the southeastern corner of the basin. The laterally persistent, basal-marginal marine sandstones associated with these cycles are informally referred to by Collins (1976) as the middle and upper sandstones. Gill and Cobban (1969) evidently believed that one of these sandstones correlates with the regressive Twentymile Sandstone Member of the Williams Fork Formation in the Sand Wash basin to the north, but, using their paleogeographic reconstructions, it is not clear which one. These two regressive sandstones have been traced in the subsurface throughout a fairly large arca in the southeastern corner of the basin. Each of these sandstones consists of a single, persistent, upward-coarsening sequence that appears to climb stratigraphically to the southeast similar to the earlier Rollins and Trout Creek Sandstone Members (pl. 1 , view $D$ ). These two younger regressive cycles therefore more closely resemble the Rollins-Trout Creek regression than do carlier regressions such as the upper Sego-Corcoran or the Cozzette.

Collins (1976, p. 25) described these two sandstones as "bar-beach-delta front sandstone similar to the Trout Creek-Rollins sandstone." Both regressive sandstones are overlain by locally important coal zones. The lower of the two sandstones, or the middle sandstone of Collins (1976), is along the line of section shown on plate 1 (view $D$ ) and is also present at Rifle Gap (pl. 2). At Rifle Gap, this sandstone is an unusually thick (135 ft), upward-coarsening shoreface sequence in which the foreshore apparently was not preserved. Ophiomorpha traces were found near the middle of the unit. The tongue of marine shale below this sandstone along the cross section shown on plate 1 (view $D$ ) may or may not be present at Rifle Gap. Because the shale interval has been highly altered by coal fires, its environment of deposition cannot be determined. A section of carbonaceous shale, clinkered coal beds, and trough crossbedded channel sandstone units as thick as $10 \mathrm{ft}$ overlies the sandstone.

Another marginal-marine sandstone, the Lion Canyon Sandstone Member of the Williams Fork Formation, is much higher in section in the northeastern corner of the basin. It was originally named and mapped in the northeastern part of the basin by Hancock and Eby (1930). Gill and Cobban (1969) correlated it with the Lewis Shale transgression northeast of the basin and placed it in the Baculites clinolobatus zone. The Lion 
Canyon was not examined in the present study, and it is unclear from published literature if it is a transgressive or regressive sandstone.

Coals are scattered throughout an 800- to 1,000 foot-thick interval above the top of the Lion Canyon Sandstone Member. Although the Lion Canyon disappears a short distance south of Meeker along the Grand Hogback, the coaly section appears to persist farther to the south, along the Grand Hogback, and to the west in the subsurface. This coal zone, called the Lion Canyon coal group, was traced by Collins (1976) along the Grand Hogback as far south as Coal basin (fig. 3), where it appears to correlate, in part, with the Keystone coal group of the southern part of the Grand Hogback. The Keystone coal group was originally used by Gale (1910) to describe exposures of coal along the Colorado River at Newcastle. Coals in the Keystone coal group have been mined at Rifle Gap (pl. 2), where an old mine shaft in the Keystone coal group is approximately 2,950 ft stratigraphically above the Rollins Sandstone Member.

Remnants of the Lion Canyon coal group appear to surface again along the northwestern margin of the basin. In the Smizer Gulch quadrangle, about $25 \mathrm{mi}$ west of Meeker, Hail (1973) mapped coals that may be laterally equivalent to the Lion Canyon coal group. The base of Hail's coal zone is about $2,000 \mathrm{ft}$ above the top of the Trout Creek Sandstone Member or about the same distance above the Trout Creek as the base of the Lion Canyon coal group along the hogback. The coal zone in the Smizer Gulch quadrangle, however, is much closer to the top of the Mesaverde than is the Lion Canyon coal group along the hogback. The interval from the top of the Trout Creek to the top of the Mesaverde thins from about $4,000 \mathrm{ft}$ along the hogback to about $2,700 \mathrm{ft}$ in Smizer Gulch quadrangle. If this thinning results from a westward increase in the amount of beveling by the overlying unconformity, then the coal zone in Smizer Gulch quadrangle may correlate with the Lion Canyon coal group. Subsurface control is too sparse, however, to resolve this problem. Farther to the west, the Mesaverde continues to thin and the coal group appears to be truncated by the overlying unconformity.

Teredo-bored logs and hummocky crossbedding, both thought to be marine indicators, recently have been reported near the top of the Mesaverde in the vicinity of Rifle Gap (Lorenz, 1982; Lorenz and Rutledge, 1985). The two uppermost sandstones of the Mesaverde in this area display large-scale lateral accretion units and are interpreted by Lorenz to have been deposited in distributary channel and estuarine environments. Teredo borings may not be a particularly reliable marine indicator, however, because salt-water wedges commonly invade many large, present-day coastal river systems during periods of low flow. For example, in the Mississippi River, in summer, sharks and other marine animals are often caught at New Orleans-more than $75 \mathrm{mi}$ from the mouth of the Mississippi River. Lorenz (1982) also suggested that these sandstones are related to the Lewis transgression, but they appear to be too high in the section for that to be the case, unless the earlier correlation of the Lion Canyon coal group with the Keystone coal group is in error. Until diagnostic fossils such as baculites are found, it is impossible to fit these Teredo-bearing sandstones into the regional stratigraphy. Their presence does suggest that during the latter part of the Late Cretaceous Maestrichtian, at which time these two sandstones were deposited, the Late Cretaceous seaway was not too far east of the present eastern margin of the Piceance basin.

\section{Fluvial Deposition}

The upper part of the Mesaverde consists mostly of fluvial rocks deposited on the coastal plain behind the retreating Late Cretaceous coastline (fig. 4). The initial onset of fluvial deposition ranges from well below the interval of the Rollins and Trout Creek Sandstone Members in the northwestern corner of the basin to perhaps 800-1,000 ft above the Rollins and Trout Creek in the southeastern corner. Although the area of fluvial deposition shifted back and forth across the basin with each succeeding transgression and regression, fluvial deposition occurred throughout the entire Piceance basin for extended periods of time. Chronostratigraphic relationships in these fluvial rocks are poorly understood. Pollen and mollusks are the only fossils thus far found in these rocks, and, because they have much longer ranges than the rapidly evolving ammonites found in the marine sequences, no widespread key beds or key sequences of beds exist. The fluvial part of the Mesaverde consists almost totally of lenticular channel sandstones and finegrained flood-plain deposits.

In some areas, channel sandstones are stacked into sandstone units several hundreds of feet thick. At one time these sandstone units were believed to represent unique events that occurred along the entire coastal plain and hence to be useful in subdividing this monotonous sequence into approximate chronostratigraphic units; however, if traced laterally, they grade into thinner, more typical Mesaverde fluvial sandstone units. They probably represent relatively local conditions that developed along individual drainages on the coastal plain and thus are not particularly useful in developing regional stratigraphic relationships. Some of the measured sections include stacked channel sequences, which will be discussed later.

Stratigraphic relationships are complicated by the fact that the Laramide orogeny appears to have begun before deposition of the Mesaverde ceased. Laramide uplifts eventually divided the Rocky Mountain foreland 
basin into several smaller structural and sedimentary basins, but the earliest Laramide uplifts began during the late Campanian and others did not begin until the Paleocene. As a result, the boundaries of the Laramide structural and sedimentary basins were not completely defined until the Paleocene. Deposition of the Mesaverde in the Piceance basin overlaps with the onset of one of the oldest Laramide uplifts, the Sawatch uplift, southeast of the Piceance basin (Tweto, 1975). An igneous stock that postdates one of the major faults defining the Sawatch uplift has been dated by using biotite as $70.4 \pm 2.1 \mathrm{~m} . \mathrm{y}$. and by using hornblende as $69.4 \pm 2.1 \mathrm{~m} . y$. (Tweto, 1975). These ages are similar to that of the Baculites clinolobatus zone (69.5 m.y.), during which the Lion Canyon Sandstone Member was deposited; and probably at least the Mesaverde section above the Lion Canyon Member, including the Teredobearing section at Rifle Gap, was deposited while erosion was occurring over the nearby Sawatch uplift. Although the effects of the Sawatch uplift and other early Laramide uplifts on Mesaverde depositional patterns have not been adequately explored, the uplift appears to have rearranged drainage patterns and provided some sediments to the Mesaverde in the southern part of the basin. Hansley (1981) reported that fluvial Mesaverde rocks in the southern part of the basin contain an abundance of igneous rock fragments and angular feldspar grains not common in Mesaverde rocks elsewhere in the basin.

The stratigraphic nomenclature used for the fluvial part of the Mesaverde is almost as ambiguous as our understanding of this unit (fig. 4). In the northern part of the basin, the Mesaverde Group is divided into the Iles and Williams Fork Formations. The Iles extends from the top of the underlying Mancos Shale to the top of the Trout Creek Sandstone Member, and the Williams Fork Formation extends from the top of the Trout Creek to the Cretaceous-Tertiary unconformity. In areas where the Trout Creek is absent, the base of the coal zone equivalent to the Cameo-Fairfield coal zone is sometimes used to define the boundary between the Iles and the Williams Fork Formations (Hail, 1974).

In the southwestern part of the basin, along the Book Cliffs, the Mesaverde Group is divided into the Mount Garfield and the Hunter Canyon Formations (Erdmann, 1934). The Mount Garfield extends upward from the top of the Sego Sandstone to several hundred feet above the Cameo-Fairfield coal zone, at which point fluvial sandstones of the Mesaverde begin to form prominent cliffs. The Hunter Canyon extends from the base of the cliffs to the Cretaceous-Tertiary unconformity and includes the Ohio Creek Member described later. Erdmann recognized two members in the Mount Garfield, a lower coaly member and an upper barren member. The lower member extends from the top of the
Sego Sandstone to the top of the highest coaly section in the Mesaverde, which for most of the basin is the top of the Cameo-Fairfield coal zone. The upper member extends from the top of the highest coaly section to the base of the overlying, much sandier Hunter Canyon Formation. Erdmann (1934, p. 40) described the contact with the overlying Hunter Canyon Formation as "more or less arbitrary and***based on various lithologic differences. The overlying Hunter Canyon formation is differentiated from the Mount Garfield formation chiefly by the difference in character of its sandstones, which are more numerous and also coarser, grayer, and more massive than those below." The vagueness of this boundary has led to many mapping problems, and, as a result, other systems of nomenclature have been suggested. Young $(1955,1966)$ extended the Price River Formation into the Piceance basin eastward from the Uinta basin and recognized two named facies in the Price River Formation, the Neslen facies or lower coal-bearing rocks and the overlying Farrer facies or non-coal-bearing rocks. The terms Mount Garfield and Hunter Canyon Formations have precedence in the Piceance basin, however, and are still widely used.

In the eastern part of the basin, the Mesaverde crops out along the Grand Hogback and generally is not subdivided above the Cameo-Fairfield coal zone except (1) in the southeastern corner of the basin where, as previously discussed, one or possibly two marine sandstones are above the Rollins and Trout Creek Sandstone Members and (2) in the northeastern corner where the Lion Canyon Sandstone Member of the Williams Fork Formation crops out. Outside of these limited areas, the Mesaverde above the Rollins and Trout Creek Sandstone Members is called either the Williams Fork Formation of the Mesaverde Group (Hancock and Eby, 1930; Collins, 1976) or simply the Mesaverde Formation. Collins (1976) summarized some of these nomenclature problems with the Mesaverde.

In general, the fluvial part of the Mesaverde contains 40-60 percent lenticular sandstone units (R.C. Johnson, unpub. data, 1986), but, at any given locality, the sandstone is not evenly distributed in the stratigraphic section. In some intervals, stacking of channels produces highly sandy sections several hundreds of feet thick, whereas in other intervals, few channels exist. As previously mentioned, the stacked channel intervals are not persistent and grade laterally into less sandy intervals.

At Hunter Canyon, the Mesaverde above the Cameo-Fairfield coal zone is probably totally fluvial in origin. The interval is $1,846 \mathrm{ft}$ thick and consists of a lower zone of mostly individual channel sandstones and an upper zone of mostly stacked channel sandstones (pl. 2 ). The contact between the lower and upper zones is about $800 \mathrm{ft}$ above the contact between the Mount Garfield and Hunter Canyon Formations of Erdmann 
(1934). The lower zone is $1,208 \mathrm{ft}$ thick and contains about $549 \mathrm{ft}$ or 45 percent sandstone. Individual channel sandstones are as thick as $37 \mathrm{ft}$ and generally fine grained; they display parallel-horizontal, drift-ripple, and trough cross laminations and large-scale lateral accretion units. Many of the channels probably intersect one or more channels in the third dimension, and they were deposited by streams having a moderate to high sinuosity.

The upper zone is $638 \mathrm{ft}$ thick and contains about $524 \mathrm{ft}$ or 82 percent sandstone. These sandstones are fine to coarse grained and locally contain lenses of dark chert and quartzite pebbles and cobbles. They display parallelhorizontal and trough cross laminations and generally lack the drift-ripple laminations common in the lower zone. Some of the sandstone units display large-scale lateral accretion bedding. The upper sandstone zone probably is a single reservoir except for some local, isolated reservoirs formed by nonpersistent clayey intervals. The sandstones were probably deposited by sand-choked stream systems that varicd in character from medium to low sinuosity to possibly braided. Sandstones in the upper $300 \mathrm{ft}$ are light gray to white as a result of alteration of feldspar during the time interval represented by the unconformity described next. These sandstones have recently been redefined as the Ohio Creek Member of the Hunter Canyon Formation (Johnson and May, 1980).

The two sandstone zones in the Hunter Canyon Formation persist along the Book Cliffs at least as far southeast as the Lands End measured section (pl. 2). At Lands End, the lower zone is $851 \mathrm{ft}$ thick and contains $325 \mathrm{ft}$ or 35 percent sandstone. Individual sandstone units are from a few feet to as much as $36 \mathrm{ft}$ thick; they are similar to sandstones in the lower zone at Hunter Canyon and were probably deposited by streams having a medium to high sinuosity. The upper sandy zone is only $315 \mathrm{ft}$ thick and contains $250 \mathrm{ft}$ or 79 percent sandstone. It is similar to the upper sandy zone at Hunter Canyon, except that no conglomeratic lenses were found and the paleoweathering zone beneath the unconformity is not well developed. The top of the Mesaverde Formation is not well exposed in the area of Lands End and probably is in the covered interval just below the top of the section. The sandy zone may have thinned because of a lateral facies change or because of truncation on the overlying unconformity. Overall, the Mesaverde thins from Hunter Canyon to Lands End. The interval from the top of the Rollins Sandstone Member to the Cretaceous-Tertiary unconformity thins from $1,965 \mathrm{ft}$ at Hunter Canyon to 1,542 $\mathrm{ft}$ at Lands End.

At the White River section (pl. 2), the Iles Formation was probably deposited in a complex system of deltaic, lower-coastal-plain, and normal fluvial environments. The only shoreface sandstone is the Sego Sandstone. Most of the relatively thin channel sandstones were probably deposited by lower-coastal-plain and delta-plain distributary channcls. A 140-foot-thick sequence of stacked channel sandstones 160-290 ft below the top of the Trout Creek equivalent may have been deposited by a major coastal-plain river, or it may be a sequence of stacked distributary channel sandstones.

The main part of the fluvial sequence at the White River section (pl. 2) begins at the top of the CameoFairfield coal zone. The fluvial interval at the White River section is considerably different from those at Hunter Canyon and Lands End. At the White River section, a sandy zone of stacked channel sandstones is just above the Cameo-Fairfield equivalent, whereas at Hunter Canyon and Lands End, stacked channel sandstones are at the top of the Mesaverde. At the White River section, the sandy zone is $868 \mathrm{ft}$ thick and contains $602 \mathrm{ft}$ or 69 percent sandstone. The sandstones contain parallel-horizontal, trough cross, and drift-ripple laminations. Large-scale lateral accretion bedding was not observed, but exposures at the White River section are limited. The sandstones probably were deposited by sand-choked streams having medium sinuosity. The sandy zone grades upward into a less sandy zone that is $523 \mathrm{ft}$ thick and contains $256 \mathrm{ft}$ or 49 percent sandstone. Individual channel sandstones in the upper zone range from a few fect to as much as $44 \mathrm{ft}$ thick and are similar to sandstones in the sandy zone below.

Above this less sandy zone, a zone $557 \mathrm{ft}$ thick contains almost no channel sandstones. This zone consists mostly of gray carbonaceous shale interbedded with thin sandstones that display drift-ripple and smallscale trough cross laminations. These thin sandstones are similar to modern crevasse splay deposits. The upper part of the Williams Fork Formation at the White River section is probably Maestrichtian in age. Hail (1974) collected the fossils Tulotomops thompsoni and Loiplacoides cf. L. nebrascensis from near the top of the Williams Fork Formation near the measured section, and these fossils are thought to be restricted to the Lance Formation and rocks of cquivalent age. The Lance is Maestrichtian in age, and, in the Sand Wash basin to the northeast, it is above the Lewis Shale. The lower part of the Lance is approximately the same age as the Lion Canyon coal group ncar Meeker.

Above the shaly zone, a section $165 \mathrm{ft}$ thick contains $99 \mathrm{ft}$ or 60 percent sandstone. These sandstones are 5-26 ft thick and probably were deposited by fluvial channels having medium to high sinuosity. The paleoweathering profile developed below the CretaceousTertiary unconformity, described more fully in the following section, is thin at the White River section. White kaolinitic sandstones are in only the upper $120 \mathrm{ft}$ of the section, and the kaolinitic zone is nonpersistent in the area of the White River section (Hail, 1974). 
The thickest Mesaverde section measured is at Rifle Gap (pl. 2), where the interval from the top of the Rollins Sandstone Member to the Cretaceous-Tertiary unconformity measures $3,922 \mathrm{ft}$. The marine regressive cycles described earlicr are well exposed along the almost vertically dipping outcrops, but the mostly nonmarine upper part of the Mesaverde is poorly exposed. The resistant fluvial sandstones form spectacular hogbacks, and hence these units are fairly well exposed. Because the reentrants between the hogbacks are generally covered with deep accumulations of talus, the rocks in these intervals could not be described. Presumably the intervals are composed predominantly of fine-grained rocks, but, because thin or nonresistant sandstones may also be buried by the talus, the sandstone percentages presented may be in error. The two Teredo-bearing sandstones at the top of the Mesaverde are included in the discussion of the marine part of the Mesaverde. The shift from a lower-coastal-plain coal-swamp environment to a fluvial environment is about $400 \mathrm{ft}$ above the unnamed regressive sandstone that is the highest unquestionably marginal-marine unit at Rifle Gap. At Rifle Gap, the fluvial part of the Mesaverde is about $3,100 \mathrm{ft}$ thick and contains approximately 45 percent fluvial channel sandstones. The sandstones display parallel-horizontal, trough cross, and drift-ripple laminations and probably were deposited by nonbraided streams having high to low sinuosity.

An old coal mine is about $1,000 \mathrm{ft}$ stratigraphically below the Cretaceous-Tertiary unconformity. The mine is within the Keystone coal interval, which, as previously discussed, has been traced along the hogback from Coal Ridge, south of Rifle Gap, to north of Meeker where it appears to correlate with the Lion Canyon coal group (G.H. Horn and others, unpub. sections). The two Teredo-bearing sandstones at the top of the Mesaverde are $460-860 \mathrm{ft}$ above the coal mine. The white kaolinitic zone commonly found beneath the Cretaceous-Tertiary unconformity is not present at Rifle Gap.

\section{The Cretaceous-Tertiary Unconformity}

A major regional unconformity appears to truncate the Mesaverde Formation or Group throughout most, if not all, of the Piceance basin. It appears to extend across the Douglas Creek arch and into at least the eastern part of the Uinta basin to the west (Johnson and May, 1978, 1980; Fouch and others, 1983; Johnson, 1985a). Truncation probably began near the end of the Cretaceous and continued to as late as late Paleocene along the margins of the basin. A considerable thickness of the upper part of the Mesaverde section may have been removed during the erosional period, particularly in the western Piceancc basin, along the Douglas Creck arch, and in the eastern Uinta basin. As discussed previously, the unconformity appears to bevel most of the Mesaverde section above the Lion Canyon coal group between Meeker and the Smizer Gulch quadrangle. The interval from the top of the Rollins and Trout Creek Sandstone Members to the unconformity thins from greater than 4,600 ft near Meeker to only about 2,000 ft along the western margin of the basin (Granica and Johnson, 1980). Although some of this westward thinning may have resulted from differential subsidence during Mesaverde deposition, much of it probably resulted from erosion related to the unconformity. In the western part of the Piceance basin, the age of the Mesaverde directly beneath the unconformity has been approximately determined by using pollen as being late Campanian to early Maestrichtian (Johnson and May, 1978, 1980); whereas, along the eastern margin of the basin, the age of the upper half of the Mesaverde is clearly Maestrichtian. The age of the Lion Canyon Sandstone Member, based on ammonites, is about 69.5 m.y., or about 3 m.y. younger than the Campanian-Maestrichtian boundary (Gill and Cobban, 1969).

Along the northeastern margin of the Uinta basin, adjacent to the Uinta Mountains, beveling beneath an unconformity that appears to trace into the unconformity in the Piceance basin reached the stratigraphic level of the Castlegate Sandstone (Gill and Hail, 1975). Elsewhere in the eastern part of the Uinta basin, less of the section is missing, but Late Cretaceous Maestrichtian-age Mesaverde rocks apparently are totally missing (Fouch and others, 1983). As is the case for Mesaverde rocks in the Piceance basin, available fossil dates are not precise.

We can only speculate as to the lithology of the section removed during the hiatus. It may have consisted mostly of fairly conglomeratic fluvial rocks. In the southwestern part of the Piceance basin, the uppermost 300-500 ft of Mesaverde rocks preserved beneath the unconformity are coarse grained and contain chert lenses and quartzite pebbles and cobbles. In the western Piceance and eastern Uinta basins, the thin, late Paleocene-age conglomerate and conglomeratic sandstone that commonly overlie the unconformity may be, at least in part, a lag deposit that accumulated on the unconformity surface during beveling of the underlying Mesaverde. Quartzite and chert pebbles in this thin basal Tertiary conglomerate are similar in composition to, but generally somewhat larger than, pebbles found in the underlying conglomeratic Mesaverde section.

The position of the unconformity is commonly marked by a deep paleoweathering profile that developed on the underlying rocks. In this weathering zone, observed in both surface outcrops and in the subsurface, sandstones are kaolinized for as far as $500 \mathrm{ft}$ below the unconformity, and a distinctive white unit can be 
observed throughout much of the basin. This white unit was originally called the Ohio Creck Formation or the Ohio Creek Conglomerate (Hills, 1890; Emmons and others, 1894; Lee, 1912) and, based on erroncous fossil identifications, was believed to be Palcocene in age and separated from the underlying Late Cretaceous-age Mesaverde by an unconformity. Conglomeratic lenses in this white unit at its type locality along Ohio Creek in the southernmost part of the basin and at many other localities along the southwestern margin of the basin were believed to be confined solely to the white sandstones.

The presence of these conglomeratic lenses, along with the erroneous Paleocene date, resulted in many true Paleocene-age conglomerates in other parts of the basin, such as the basal Tertiary conglomerate described above, being mapped as Ohio Creek. Johnson and May (1978, 1980) recognized this white kaolinitic zone as a paleoweathering zone developed on preexisting rocks and by using palynomorphs determined it to be Late Cretaccous in age or indistinguishable in age from underlying Mesaverde rocks. They also demonstrated that the basal contact was gradational with the underlying Mesaverde and pointed out that scattered conglomeratic lenses in the Mesaverde considerably below the base of the white zone indicate that the two features used to originally define the Ohio Creek, the white color and the presence of conglomeratic lenses, are independent of each other. Johnson and May redefined the Ohio Creek as the white kaolinitic zone developed beneath the CretaceousTertiary unconformity, a zone that may or may not contain conglomeratic lenses, and they reduced the rank of the Ohio Creek to a member of the underlying Mesaverde or Hunter Canyon Formation, depending on local nomenclature.

A fairly typical section of the Ohio Creek Member is at Hunter Canyon (pl. 2). The white zone is about 300 $\mathrm{ft}$ thick, and conglomeratic lenses are scattered throughout the upper $375 \mathrm{ft}$ of Mesaverde section. Plagioclase feldspar has been almost completely destroyed in the upper $200 \mathrm{ft}$ of section, and potassium feldspar has been destroyed in the upper $20 \mathrm{ft}$ (Johnson and May, 1980). The upper $20 \mathrm{ft}$ of section appears to be a preserved paleosol zone, and kaolinite constitutes as much as 60 percent of the rock. This high clay content is similar to those of many modern lateritic soils, in which almost all weatherable minerals have been removed and the cation exchange is low.

The white-weathering zone can be traced below the surface throughout much of the basin by using Amstrat (American Stratigraphic Company) sample descriptions and geophysical logs, but the zone appears to be thickest and best developed in the southwestern part of the basin. Throughout much of this area, the unconformity is directly overlain by late Paleocene-age black carbon- aceous shales. At Hunter Canyon, for instance, the weathered zone is overlain by about $160 \mathrm{ft}$ of black carbonaceous shale. Buildup of kaolinite might have been caused in part by the acid conditions that existed during deposition of the overlying organic-rich sediments (Young, 1982); if so, the kaolinitic zone would be similar to the kaolinitic underclay that forms under a coal bed. The kaolinitic zone is much thicker than a typical underclay, however, and also is in areas where overlying lower Cenozoic rocks are not organic rich. The kaolinitic zone was traced along its outcrop southeastward to the $\mathrm{DeBe}$ que area, where it is overlain in sharp contact by nonkaolinized, brown conglomeratic sandstone (Johnson and May, 1978), and it was traced to the west into the Douglas Pass area, where it is overlain by varicolored mudstone and gray nonkaolinized conglomeratic sandstone (Johnson, 1984). At the White River section, the weathercd zone is overlain by olive-green to gray claystone and light-brown to light-gray, nonkaolinitic sandstone (Hail, 1974). Deep weathering probably occurred throughout the basin during the CretaceousTertiary hiatus, regardless of the lithology of the overlying lower Cenozoic rocks, and, in certain areas of the southwestern part of the basin, kaolinization may have been enhanced by percolation of acid ground water through black carbonaceous shale during the late Paleocene.

In some areas, the exact position of the unconformity is hard to determine. Small, white sandstone channels are locally in the basal $50 \mathrm{ft}$ of the overlying Paleocene and Eocene Wasatch Formation. These channels were first observed directly above the unconformity ncar DeBeque (Johnson and May, 1980), where they are filled with coarse pebbles and cobbles; they have also been reported in the Baxter Pass area on the Douglas Creek arch (Johnson, 1985b). These white basal sandstones of the Wasatch probably formed by reworking of the underlying kaolinitic zone. While the unconformity was slowly onlapped by Wasatch sediments, nearby exposures of weathered Mesaverde rocks could have acted as a source. In areas of good exposure, these Wasatch sandstones are easy to distinguish from the underlying weathered Mesaverde, but where exposures are poor, such as the Baxter Pass quadrangle, they are difficult to map (Johnson, 1985b).

Onlapping of the unconformity by younger sediments probably began in the eastern part of the Piceance basin during early to middle Paleocene time (Hail, 1973). Active sedimentation gradually spread westward and, by late Paleocene or early Eocene time, eventually covered the Douglas Creek arch along the western margin of the basin (Johnson and Keighin, 1981; Johnson, 1985a). As a result, the Mesaverde was exposed to surface weathering and erosion for a much longer time in the western part of the basin than in the eastern part. 
This is in agreement with the apparent increase in the amount of Mesaverde that has been beveled toward the west and southwest.

\section{OIL AND GAS PRODUCTION IN THE MESAVERDE}

Gas and minor amounts of liquid hydrocarbons have been produced from the Mesaverde throughout the Piceance basin (table 1). Figures 9-11 outline the producing fields in 1977,1981 , and 1984, respectively. Most Mesaverde gas fields are in the Colorado River canyon and to its south. The most productive stratigraphic units in this area are the Corcoran and Cozzette Members, but production from both the fluvial part of the Mesaverde and the Rollins Sandstone Member has also been locally established. Production north of the Colorado River is mostly from the fluvial part of the Mesaverde. Minor Castlegate production has been established on the Douglas Creek arch.

Although the Mesaverde has been productive both on and off structure, the majority of gas produced thus far has been from two large closed structures, the Divide Creek and the Wolf Creek anticlines, located along the southeastern margin of the basin (fig. 3). The Divide Creek field was discovered in 1956 and produces mainly from the Corcoran and the Cozzette, but some Rollins and Trout Creek and fluvial Mesaverde production has also been established. Initial production figures for wells on these two anticlines are considerably higher than for Mesaverde wells elsewhere in the basin and are as high as 15.9 million cubic feet of gas per day (MMCFD) for the Divide Creek anticline and as high as 2.7 MMCFD for the Wolf Creek anticline.

Off structure, the Mesaverde has been productive throughout the gently dipping southwestern flank of the basin. Along the southeastern margin of the basin, shallow production (depths of less than 5,000 ft) has been established in the Shire Gulch, Plateau, and Buzzard Creek fields, mainly from the Corcoran and Cozzette. These fields have been expanded considerably since 1977 and have more or less coalesced into one large gas field. Along the Book Cliffs, production has been established within $6 \mathrm{mi}$ of Mesaverde outcrops. Wells in the Plateau field produce little or no gas prior to hydraulic fracturing (Chandler and Associates Incorporated, 1980), but after fracturing, initial production rates are about 440 thousand cubic feet of gas per day (MCFD). These relatively low productivity gas wells are economical because of the shallow drilling depths. Mcsaverde production has also been established in the structurally deeper parts of the basin at the Rulison, Sheep Creek, and Vega fields. The Sheep Creek and Vega fields produce from the Corcoran and the Cozzette, and, although production at the Rulison field originally was mostly from the lower half of the fluvial part of the Mesaverde, deeper completions have occurred recently in the Corcoran and the Cozzette Members. Significant volumes of gas have been produced from naturally fractured tight Cozzette reservoirs in the DOE MWX well no. 1 (also known as MWX-1) (Branagan and others, 1984).

North of the Colorado River canyon and south of the Garfield-Rio Blanco County line, little Mesaverde production has been established. Almost no Mesaverde tests have been drilled in this area, partly because of the relatively deep drilling depths, but mostly because the area consists primarily of a naval oil-shale reserve and patented oil-shale land owned by oil companies, and there is little incentive to establish oil and gas production except to protect against offset gas-well drainage. A relatively minor amount of Mesaverde production has been established north of the Garfield-Rio Blanco County line, mostly on unpatented land. Some of this production results from a limited amount of deeper drilling in shallow Tertiary gas fields, such as the Piceance Creek dome, but some small fields produce principally from the Mesaverde. Castlegate production has been established in the Douglas Creek arch area at the Texas Mountain, Douglas Creek North, Douglas Creek South, Dragon Trail, and Hells Hole Canyon fields. Fluvial Mesaverde production has been established at the White River dome and Sulfur Creek fields. Relatively minor structural closure may exist at the Mesaverde level on the White River dome, but no Mesaverde closure exists on the Piceance Creek dome. Several hundred feet of closure exists on this structure at the surface, but the closure appears to be lost at the Mesaverde level as a result of a pronounced eastward thickening of both the Upper Cretaceous Mesaverde section and the lower Cenozoic Wasatch, Fort Union, and Green River sections.

\section{Extent of the Mesaverde Low- Permeability Gas Accumulation}

The maps showing Mesaverde production (figs. 9-11) demonstrate that the Mesaverde is capable of producing some gas throughout most of the basin. It is more difficult to determine how much of the Mesaverde is gas bearing at any given locality in the basin, but such an estimate is needed before the total in-place gas resources of the Mesaverde can be calculated. Drill-stem test results and perforation recoveries have been plotted on the cross sections (pl. 1) in an attempt to better define the thickness of Mesavcrde section that is gas bearing. (For more detailcd rccovery data, see Johnson (1979a,b,c,) and Johnson and others $(1979 a, b, c)$.) The 
Table 1. Mesaverde oil and gas production through 1985

[Fluvial producing interval includes Cameo-Fairfield coal zone. Oil in barrels, gas in cubic feet. N.A.,not available. Data from the Colorado Oil and Gas Commission, 1985]

\begin{tabular}{|c|c|c|c|c|c|c|}
\hline \multirow[b]{2}{*}{ Field } & \multirow{2}{*}{$\begin{array}{l}\text { Discovery } \\
\text { defe }\end{array}$} & \multirow{2}{*}{$\begin{array}{l}\text { Producing } \\
\text { interval }\end{array}$} & \multicolumn{2}{|c|}{1985} & \multicolumn{2}{|c|}{ Cumulative } \\
\hline & & & Oil & Gas & Oil & Gas \\
\hline $\begin{array}{l}\text { Baldy Creek ......... } \\
\text { Baxter Pass .......... }\end{array}$ & $\begin{array}{l}1959 \\
\text { N.A. }\end{array}$ & $\begin{array}{l}\text { Regressive marine } \\
\text { Fluvial....................... }\end{array}$ & $\begin{array}{l}0 \\
0\end{array}$ & $\begin{array}{r}29.945 \\
0\end{array}$ & $\begin{array}{l}0 \\
0\end{array}$ & $\begin{array}{r}367,205 \\
4,031\end{array}$ \\
\hline Bubard ..................... & 1958 & $\begin{array}{c}\text { Regressive marine } \\
\text { Fluvial.............. } \\
\text { Undifferentiated... } \\
\text { Total }\end{array}$ & $\begin{array}{l}0 \\
0 \\
0 \\
0\end{array}$ & $\begin{array}{l}35,979 \\
19,449 \\
8,143 \\
63,571\end{array}$ & $\begin{array}{l}0 \\
0 \\
0 \\
0\end{array}$ & $\begin{array}{r}134,142 \\
1,532,125 \\
66,563 \\
1,732,030\end{array}$ \\
\hline $\begin{array}{l}\text { Buzzard Creck....... } \\
\text { Calf Canyon....... } \\
\text { Coal Basin.......... } \\
\text { Coal Gulch.......... }\end{array}$ & $\begin{array}{l}1955 \\
1972 \\
1983 \\
1966\end{array}$ & $\begin{array}{l}\text { Undifferenciated... } \\
\text { Fluvial.............. } \\
\text { Regressive maxine } \\
\text { Fluvial............... }\end{array}$ & $\begin{array}{r}0 \\
0 \\
177 \\
0\end{array}$ & $\begin{array}{r}81,995 \\
8,606 \\
49,500 \\
7,447\end{array}$ & $\begin{array}{r}0 \\
0 \\
602 \\
0\end{array}$ & $\begin{array}{r}5,083,877 \\
174,865 \\
148,473 \\
156,608\end{array}$ \\
\hline Coon Hollow....... & 1958 & $\begin{array}{l}\text { Regressive marine } \\
\text { Fluvial ............. } \\
\text { Toual }\end{array}$ & $\begin{array}{l}0 \\
0 \\
0\end{array}$ & $\begin{array}{r}6,693 \\
55,083 \\
61,776\end{array}$ & $\begin{array}{l}0 \\
0 \\
0\end{array}$ & $\begin{array}{l}115,980 \\
\frac{377,841}{493,821}\end{array}$ \\
\hline $\begin{array}{l}\text { DeBeque............. } \\
\text { Divide Creek....... } \\
\text { Douglas Creek N. } \\
\text { Douglas Creek S.. } \\
\text { Dragon Trail ........ } \\
\text { Floating Lake...... } \\
\text { Grand Mesa........ } \\
\text { Hells Gulch ......... } \\
\text { Hells Hole Canyon }\end{array}$ & $\begin{array}{l}1902 \\
1956 \\
1956 \\
1963 \\
\text { N.A. } \\
1984 \\
1958 \\
1964 \\
1951\end{array}$ & $\begin{array}{l}\text { Fluvial.............. } \\
\text { Undifferentiated... } \\
\text { Regressive marine } \\
\text { Regressive merine } \\
\text { Regressive marine } \\
\text { Regressive marine } \\
\text { Fluvial............... } \\
\text { Fluvia!.............. } \\
\text { Regressive marine }\end{array}$ & $\begin{array}{l}0 \\
0 \\
0 \\
0 \\
0 \\
0 \\
0 \\
0 \\
0\end{array}$ & $\begin{array}{r}33,686 \\
823,824 \\
170,757 \\
11,593 \\
36,301 \\
2,135 \\
0 \\
0 \\
0\end{array}$ & $\begin{array}{r}112 \\
0 \\
0 \\
0 \\
0 \\
0 \\
0 \\
0 \\
0\end{array}$ & $\begin{array}{r}517,512 \\
49,273,089 \\
223,821 \\
284,937 \\
90,569 \\
2,135 \\
741 \\
150,397 \\
369,048\end{array}$ \\
\hline $\begin{array}{l}\text { Hunter's Canyon.. } \\
\text { Logan Wash........ } \\
\text { Mamm Creek...... } \\
\text { Piceance Creek.... } \\
\text { Platcau............... } \\
\text { Powell Park....... } \\
\text { Ragged Mountain. }\end{array}$ & $\begin{array}{l}1955 \\
1982 \\
1959 \\
1930 \\
1958 \\
1957 \\
1983\end{array}$ & 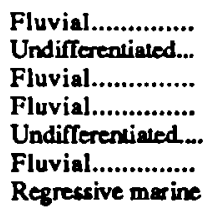 & $\begin{array}{r}0 \\
8 \\
0 \\
1,981 \\
1,074 \\
0 \\
642\end{array}$ & $\begin{array}{r}89,762 \\
157,873 \\
31,314 \\
342,188 \\
1,574,595 \\
0 \\
269,333\end{array}$ & $\begin{array}{r}0 \\
169 \\
443 \\
13,291 \\
4,873 \\
3,102 \\
0\end{array}$ & $\begin{array}{r}3,200,456 \\
824,108 \\
818,684 \\
1,985,844 \\
19,123,723 \\
16,354 \\
633,866\end{array}$ \\
\hline Rulison.................... & 1956 & $\begin{array}{c}\text { Fluvial............. } \\
\text { Regressive marine } \\
\text { Total }\end{array}$ & $\begin{array}{r}1,982 \\
\frac{0}{1,982}\end{array}$ & $\begin{array}{r}326,974 \\
1,666 \\
328,640\end{array}$ & $\begin{array}{r}13.184 \\
0 \\
12.184\end{array}$ & $\begin{array}{r}7,075,097 \\
2,409 \\
7,077,506\end{array}$ \\
\hline Sage Brush IHills.. & 1978 & Fluvial.................... & 0 & 0 & 0 & 6,495 \\
\hline Sheep Creck.......... & 1958 & $\begin{array}{l}\text { Regressive marine } \\
\text { Fluvial.............. } \\
\text { Toual }\end{array}$ & $\begin{array}{l}0 \\
0 \\
0\end{array}$ & $\begin{array}{l}41,474 \\
13.096 \\
54,570\end{array}$ & $\begin{array}{l}0 \\
0 \\
0\end{array}$ & $\begin{array}{l}245,983 \\
\frac{13,096}{259,079}\end{array}$ \\
\hline Shire Gulch ......... & 1960 & $\begin{array}{l}\text { Regressive marine } \\
\text { Fluvial.............. } \\
\text { Toul }\end{array}$ & $\begin{array}{l}0 \\
0 \\
0\end{array}$ & $\begin{array}{r}37,978 \\
253,082 \\
291,060\end{array}$ & $\begin{array}{l}0 \\
\ell \\
0\end{array}$ & $\begin{array}{r}382,811 \\
1,393,258 \\
1,776,069\end{array}$ \\
\hline $\begin{array}{l}\text { Sulfur Creck ....... } \\
\text { Taiga Mountain ... } \\
\text { Texas Mountain... }\end{array}$ & $\begin{array}{l}1955 \\
1981 \\
1964\end{array}$ & $\begin{array}{l}\text { Fluvial............ } \\
\text { Regressive marine } \\
\text { Regressive marine }\end{array}$ & $\begin{array}{r}301 \\
23,431 \\
1,195\end{array}$ & $\begin{array}{r}109,102 \\
488,665 \\
91,552\end{array}$ & $\begin{array}{r}2,297 \\
60,359 \\
69,013\end{array}$ & $\begin{array}{r}504,285 \\
2,865,217 \\
4,055,617\end{array}$ \\
\hline 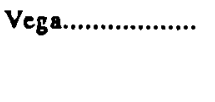 & 1977 & $\begin{array}{c}\text { Regressive marine } \\
\text { Fluvial.............. } \\
\text { Tolal }\end{array}$ & $\begin{array}{l}0 \\
0 \\
0\end{array}$ & $\begin{array}{r}3,613 \\
0 \\
3,613\end{array}$ & $\begin{array}{r}203 \\
\frac{24}{227}\end{array}$ & $\begin{array}{r}123,148 \\
\frac{75,740}{198,888}\end{array}$ \\
\hline $\begin{array}{l}\text { Whire River......... } \\
\text { Wolf Croek.......... }\end{array}$ & $\begin{array}{l}1890 \\
1960\end{array}$ & $\begin{array}{l}\text { Fluvial.............. } \\
\text { Regressive marixe }\end{array}$ & $\begin{array}{r}2,137 \\
0\end{array}$ & $\begin{array}{r}128,585 \\
0\end{array}$ & $\begin{array}{r}26,250 \\
0\end{array}$ & $\begin{array}{r}1,638,059 \\
12,629,822\end{array}$ \\
\hline
\end{tabular}

data suggest that along the margins of the basin all except perhaps the lowermost part of the Mesaverde is water bearing. The thickness of section that contains at least some gas-bearing sands increases toward the structural trough of the basin, and, along the trough of the basin, much if not all of the Mesaverde is gas bearing.
These results are similar to those for other Rocky Mountain Laramide basins. In the Deep basin of Alberta, Masters (1979) defined three zones: a shallow water-bearing zone around the margin of the basin, a deeper transition zone containing both water-bearing and gas-bearing intervals, and a deep basin center gas- 

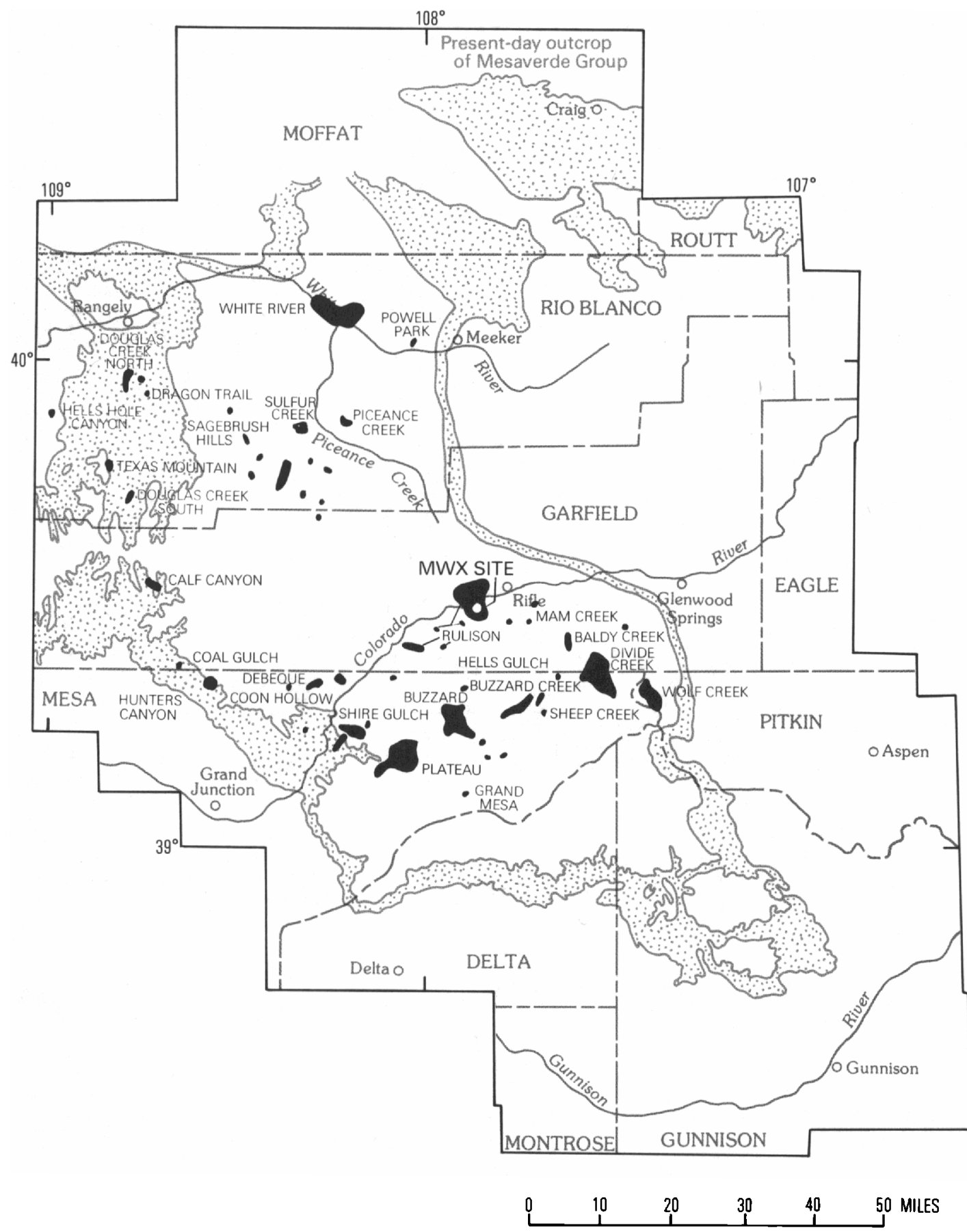

Figure 9. Mesaverde gas fields (in black) as of July 1977. Constructed using unpublished data from Petroleum Information Incorporated (Denver, Colo.).

bearing zone containing very little water. Similar threezone divisions were described by Law (1984) for the Green River basin of Wyoming and by Spencer (1983) for all Rocky Mountain Laramide basins.

Chancellor and Johnson (1986) used a combination of gas shows and production characteristics to define the predominantly gas bearing zone and the transition gas- and water-bearing zone along a line of section a few miles west of the trough of the Piceance basin. The transition zone extends from the CretaceousTertiary unconformity downward to depths of $1,000-1,700 \mathrm{ft}$, and the gas-bearing zone extends through the remaining 3,300-4,000 $\mathrm{ft}$ of Mesaverde rocks. Potential source rocks for gas are less common in the upper zone than in the lower, and Chancellor and Johnson suggested that availability of organic matter may 

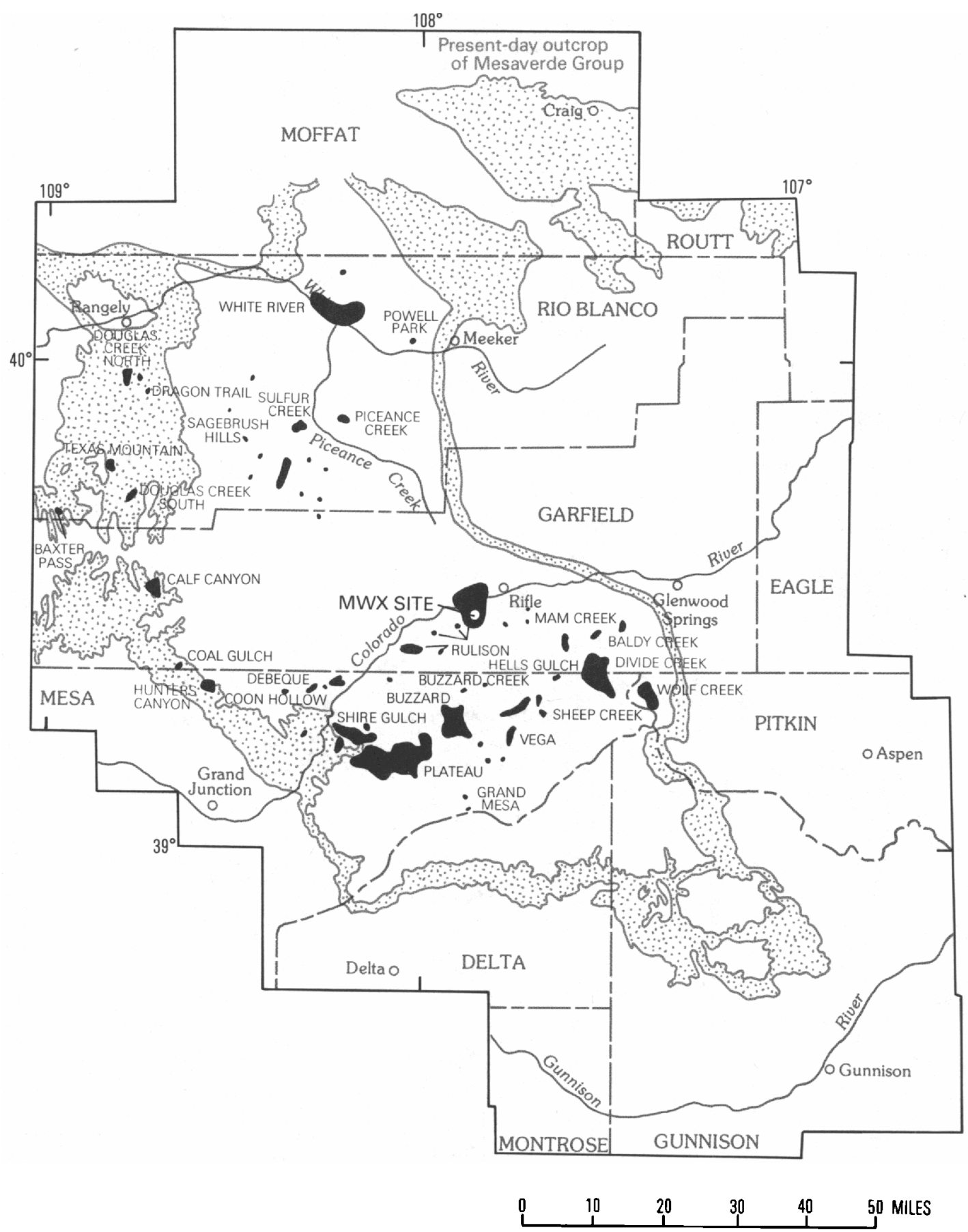

Figure 10. Mesaverde gas fields (in black) as of January 1981. Constructed using unpublished data from Petroleum Information Incorporated (Denver, Colo.).

be one important factor controlling the thicknesses of the two zones. At this time the thickness of the transition zone throughout the Piceance basin is not well defined and more detailed work is needed.

Extremely low permeabilities hinder definition of the extent of gas-bearing Mesaverde rocks in the basin. Results from drill-stem tests and perforations are difficult to interpret because reliable formation pressures are hard to measure in extremely tight rocks and because tight rocks are highly susceptible to formation damage by drilling fluids. In most cases, insufficient information is available to determine why a drill-stem test or perforation failed to produce gas.

Most of the drill-stem test and perforation recovery results for the marine regressive cycles are from the Corcoran-Cozzette interval in the southern part of the 

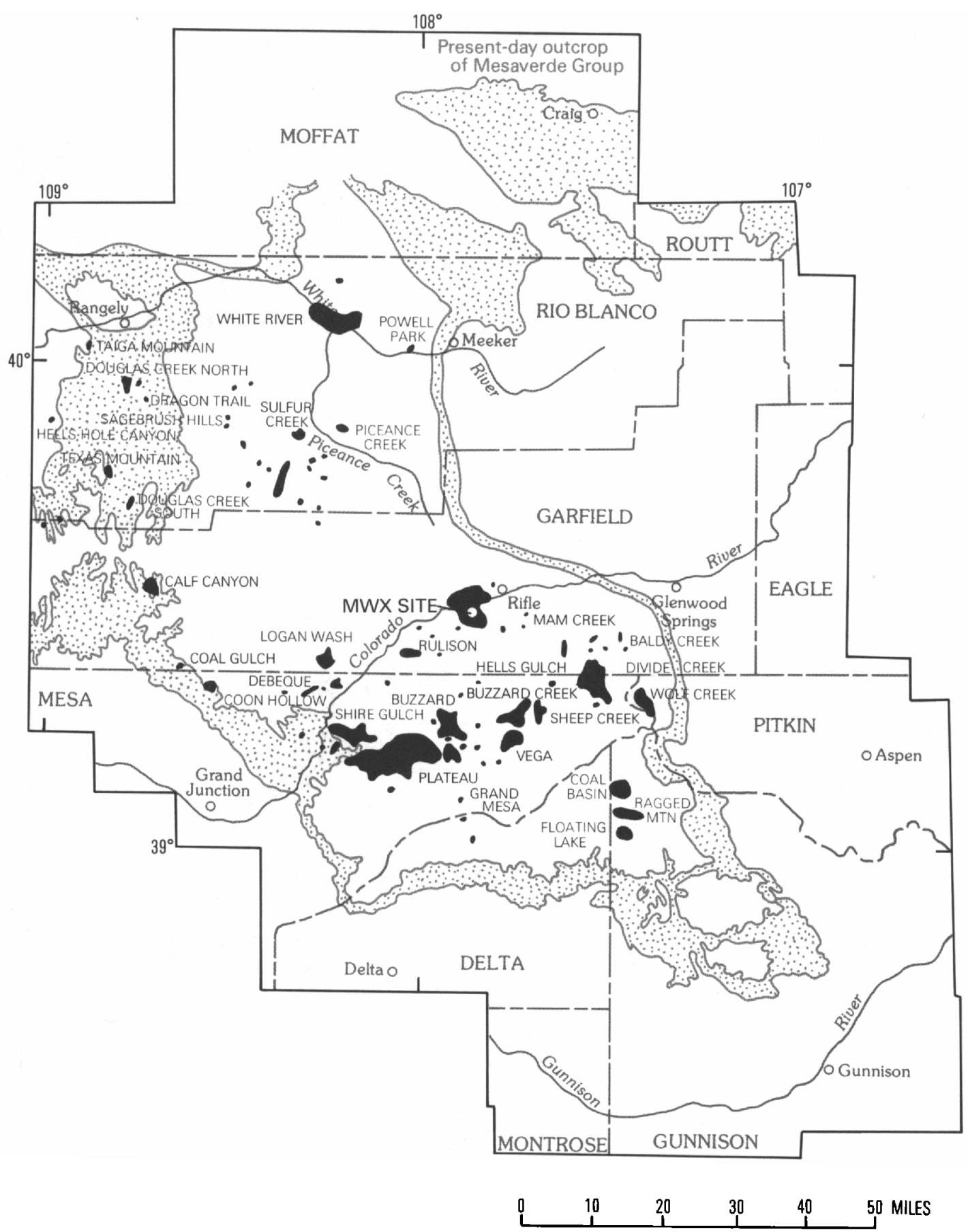

Figure 11. Mesaverde gas fields (in black) as of June 1984. Constructed using unpublished data from Petroleum Information Incorporated (Denver, Colo.).

basin (fig. 12). Many tests of the Corcoran-Cozzette interval are tight, but frequent gas shows and some water shows were encountered. Although the number of water shows seems to increase slightly toward outcrop, the Corcoran-Cozzette interval is probably capable of producing some gas surprisingly close to the present-day outcrop. As previously mentioned, gas has been produced within $6 \mathrm{mi}$ of outcrop. Tests of other regressive cycles in the basin are sparse, but the limited data available are similar to those of the CorcoranCozzette interval and consist predominantly of tight tests and some gas and a few water shows. Gas chromatography data support these results and indicate that the marine regressive cycles are predominantly gas saturated throughout the basin. 


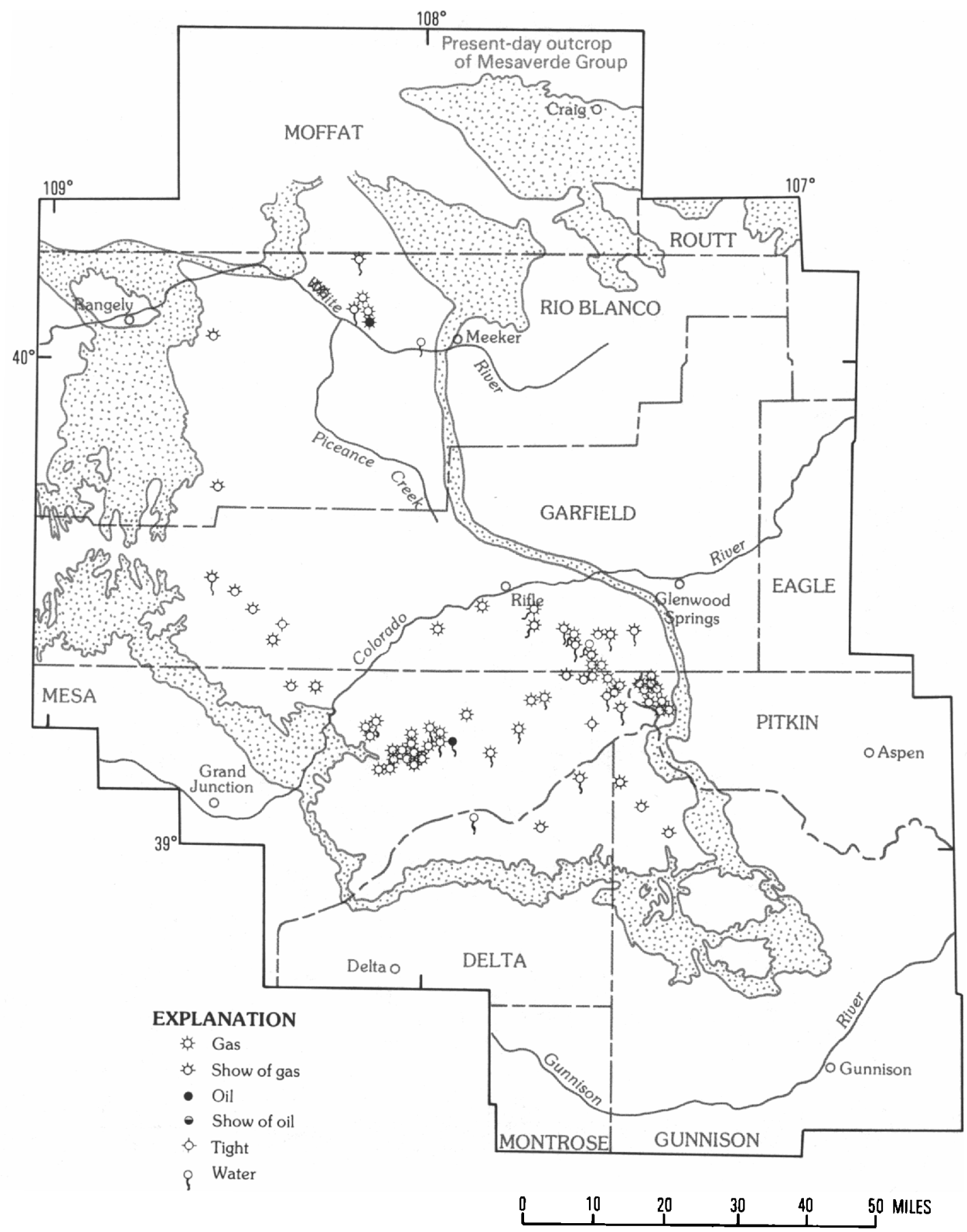

Figure 12. Results of selected drill-stem tests and perforation recoveries for Mesaverde regressive marine cycles. From Nuccio and Johnson (1981).

Although most tests of the nonmarine part of the Mesaverde are also tight, gas and some water have been recovered from the nonmarine interval throughout much of the basin (fig. 13). Similar to the underlying regressive marine cycles, gas has been found within a few miles of outcrop. The entire lower 1,500-2,500 $\mathrm{ft}$ of the fluvial part of the Mesaverde appears to be gas bearing to within 10-15 mi of outcrop throughout most of the basin.

\section{Mesaverde Reservoir Properties}

Under simulated in-place conditions, matrix permeabilitics of both fluvial and marine Mesaverde reservoirs are tight to near tight throughout most of the basin, and, in general, the reservoirs become tighter with increasing depth of burial (Spencer, 1983). Permeabilities decrease significantly if core samples are subjected to 

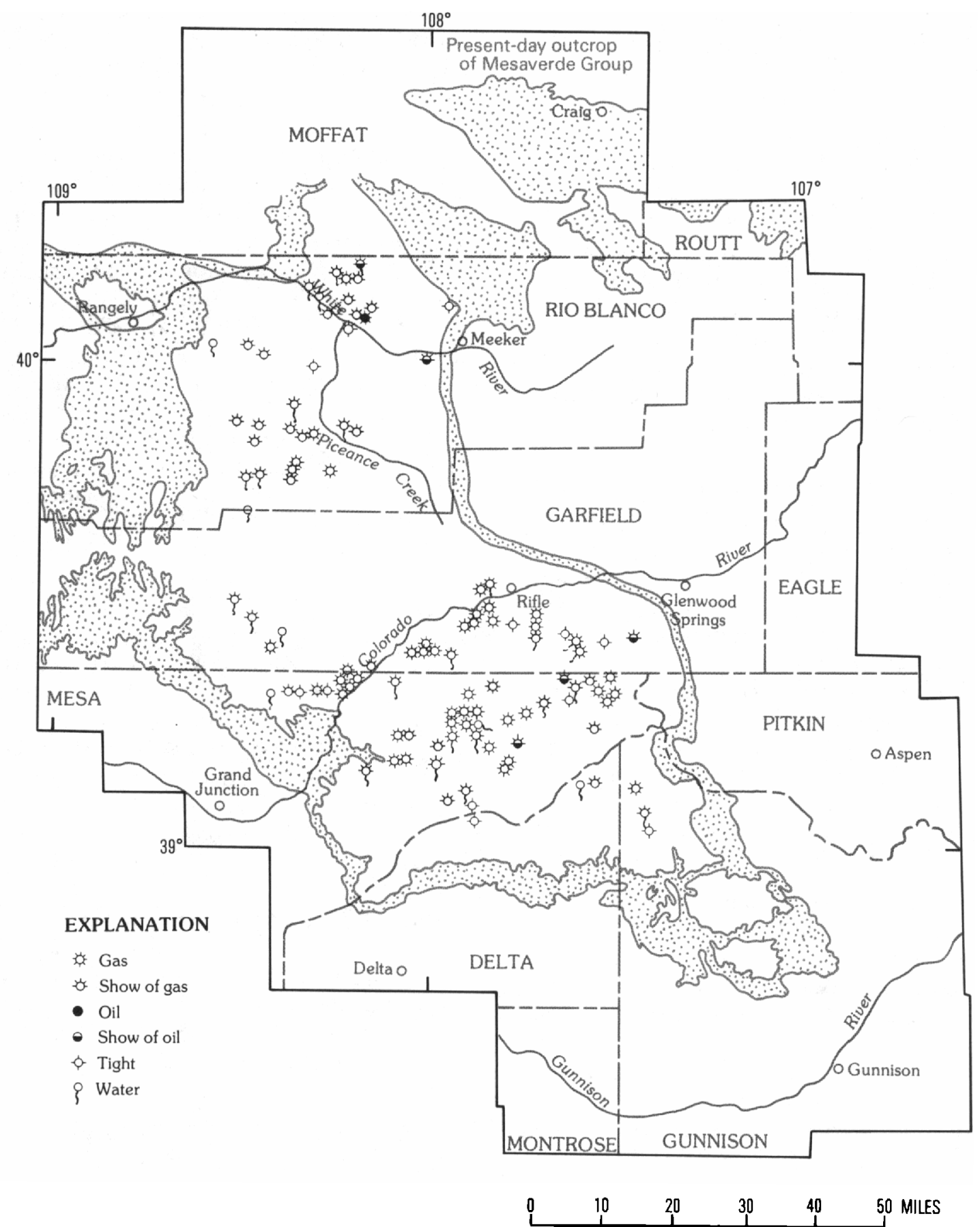

Figure 13. Results of selected drill-stem tests and perforation recoveries for fluvial part of Mesaverde Formation, including the Cameo-Fairfield coal zone. From Nuccio and Johnson (1981).

confining pressures simulating in-place stress conditions, and they are generally very sensitive to increases in water saturation (Thomas and Ward, 1972). Conventional dry permeabilities were measured in both the marine regressive cycles and the fluvial intervals of the MWX core, and most are 0.01-0.10 $\mathrm{mD}$ (millidarcy) (Pitman and Spencer, 1984); at in-place confining pressures, permeabilities to gas would be much less. Throughout the central part of the basin north of the Garfield-Rio Blanco County line, the fluvial part of the Mesaverde has low permeabilities of $0.0006-0.055 \mathrm{mD}$ (Rio Blanco Natural Gas Company, 1980).

In the shallow Plateau Creek field, an average permeability of $0.06 \mathrm{mD}$ has been reported for the Corcoran, Cozzette, and Rollins, and permeabilities of $0.1 \mathrm{mD}$ have been reported for the productive Corcoran 
and Cozzette on the Divide Creek anticline (Tichy and Rettger, 1961). Because all these permeability measurements appear to have bcen made with conventional dry core and not under in-place conditions, they are probably too high. Conventional permeabilities have been reported for core from only one well, the Twin Arrow 4-14K well (fig. 8; sec. 14, T. 3 S., R. 101 W.; unpub. data), along the western margin of the basin. Core from the shallow nonmarine part of the Mesaverde has permeabilities much greatcr than $0.10 \mathrm{mD}$. (Coring of this interval was supported by DOE.) The core was collected at depths of 982-1,211 ft within $1 \mathrm{mi}$ of outcrops of the nonmarine part of the Mesaverde, and both sandstone porosity and permeability may be high as a result of recent ground-water dissolution of matrix grains and cements.

Sandstones of the Mesaverde have low permeabilities because intense regional diagenesis has filled pore spaces with quartz, authigenic feldspar, dolomite, calcite, illite, mixed-layer illite/smectite, kaolinite, and iron-rich chlorite (Hansley and Johnson, 1980; Hansley, 1981; Pitman and Spencer, 1984). The diagenetic mineral suite varies widely between diffcrent areas of the basin and between different parts of the Mesaverde section at any given locality, and diagenesis probably began very early, before the sandstones of the Mesaverde were either deeply buried or very compacted. In the MWX core, the diagenetic suite is probably controlled in part by the environment of deposition of the individual sandstones (Pitman and Spencer, 1984).

Authigenic minerals in the uppermost sandstones of the Mesaverde just below the Cretaceous-Tertiary unconformity typically include quartz, calcite, dolomite, chlorite, and kaolinite. Authigenic minerals in the underlying fluvial scquence include minor quartz, calcite, dolomite, illite, mixed-layer illite/smectite, chlorite, and kaolinite. Below the fluvial zone, a zone referred to as the coastal or upper-delta-plain environment by Lorenz (1984) represents a transition between the coal-swamp environment of the Cameo-Fairfield coal zone below and the more normal fluvial zones above. In the present report, the coastal zone of Lorenz is included in the fluvial part of the Mesaverde. The authigenic sequence of this interval is similar to that of the fluvial zone, except that chlorite and kaolinite are usually missing. Sandstones in the Cameo-Fairfield coal zone contain complex intergrowths of ferroan (iron rich) and nonferroan dolomite, minor calcite, illite, and mixed-layer illite/smectite. Sandstones in the Corcoran and the Cozzette regressive cycles contain minor quartz, dolomite, illite, mixed-layer illite/smectite, and chlorite. Throughout the MWX core, most porosity is secondary and results from dissolution of both detrital and authigenic grains; pores are not well connected.
Several intervals in the upper $1,200 \mathrm{ft}$ of the Mesaverde were cored at the RBE-01 nuclear emplacement well (fig. 8; sec. 14, T. 3 S., R. 98 W.) and a general diagenetic sequence for sandstones in this interval has bcen suggested (Hansley and Johnson, 1980). The sandstones appear to have been strongly affected by weathering processes during the hiatus represented by the overlying Cretaceous-Tertiary unconformity, and two periods of calcite cementation and one period of quartz overgrowth development appear to predate the unconformity. During the hiatus, secondary moldic porosity developed and kaolinite and illite were precipitated. Late carbonate cements appear to postdate the hiatus. Another drill hole, the RB-MHF-3 well, is less than $1,800 \mathrm{ft}$ from the RBE-01 well, and several intervals of the upper part of the Mesaverde were cored. Examination of two sandstones that were cored in both wells indicates that the diagenetic sequence is laterally consistent.

The diagenetic history of the sandstones of the Mesaverde was also studied in core samples of the middle of the fluvial part of the Mesaverde in the Ralston Production no. 31 Federal well (fig. 8; sec. 31, T. 10 S., R. $90 \mathrm{~W}$.) in the southeastern corner of the basin (Hansley, 1981). The diagenetic history of these sandstones has been strongly influenced by the high percentage of unstable fine-grained igneous rock fragments not found in Mesaverde rocks in other parts of the basin. These rock fragments may have been derived from the Sawatch uplift southeast of the basin, which, as previously discussed, was actively rising during Mesaverde deposition (Tweto, 1975). The sandstones contain an abundance of authigenic albite, as well as the typical Mesaverde diagenetic suite of chlorite, quartz, calcite, and kaolinite cements. Hansley (1981) believed that authigenic albite precipitated because of a favorable chemical environment produced by the presence of a high percentage of unstable lithic fragments.

\section{The Role of Natural Fractures in Mesaverde Gas Production}

A growing amount of evidence indicates that natural fractures are the primary conduits for fluid movement in the Piceance basin and that these fractures play a vital role in most, if not all, Mesaverde tight-gas production. A well-developed natural fracture system is probably a major cause of the much higher than expected production potential of otherwise tight sandstones of the Corcoran and Cozzette Members on the Divide Creek anticline (Tichy and Rettger, 1961; Gunter, 1962) and at the MWX site. Mesaverde wells on the Piceance Creek dome probably are far more productive than Mesaverde wells drilled off structure primarily because the dome is highly fractured (Chancellor, 1977). At the Mesaverde 
level, the Piceance Creek dome is not a dome but rather a structural nose having little or no closure. Stright and Gordon (1983) analyzed long-term production decline curves for Wasatch, Mesaverde, and "Mancos B" wells in the basin and found that the curves could be modeled by using linear flow equations. Results of this modeling indicate that production was mostly from very long fractures, much longer than those that would result from hydraulic fracture treatments performed on the wells.

The importance of natural fractures is illustrated by an example from the MWX field laboratory. In the MWX-1 well, perforations in the Cozzette Member would not produce gas. After a small breakdown using 55 barrels of 2 percent $\mathrm{KCl}$ water, the interval produced at a rate of 320 MCFD (thousand cubic feet per day) (Spencer, 1984). Flow rates later increased to greater than 1 million cubic feet per day (MMCFD), and pressure drawdown was detected in the nearby MWX-2 well, about $130 \mathrm{ft}$ from the MWX-1 well, in less than 2 hours. Drawdown would not have been detected this quickly unless the small breakdown had intersected an open natural fracture system (Branagan and others, 1984). Open fractures were also observed in the MWX core (Clark, 1983; Pitman and Sprunt, 1984; Sattler, 1984).

\section{Formation Pressures in the Mesaverde}

Reliable formation pressure data are difficult to obtain for tight rocks such as the Mesaverde in the Piceance basin. In most cases, only a small amount of drilling fluids or gas is recovered on drill-stem tests and the shut-in pressure buildups are much too low to be extrapolated to the formation pressures. Overpressured zones can cause blowouts during drilling, and they also tend to prop open natural fracture systems and thus increase the potential productivity of a formation.

In addition to being useful during production, pressure data are required to understand the hydrodynamics of the basin. Formation fluids move toward areas having the lowest potentiometric elevations, and this movement can either trap hydrocarbons or cause them to migrate. A normal pressure gradient in a reservoir in which saline water is the pressuring fluid is about $0.43 \mathrm{psi} / \mathrm{ft}$ (pounds per square inch per foot); however, in thick low-permeability gas-saturated intervals such as the Mesaverde in the Piceance basin, gas may be the primary pressuring fluid (Gies, 1984). In these intervals, the pressure gradients should be much lower than $0.43 \mathrm{psi} / \mathrm{ft}$ because gas is much lighter than saline water. Pressure gradients in the gas-saturated section of the Deep basin of Alberta are less than 0.43 $\mathrm{psi} / \mathrm{ft}$ but considerably greater than would be predicted if gas is the pressuring fluid and may indicate active gas migration from deeper areas of the basin (Gies, 1984).
The tremendous topographic relief in the Piceance basin is an unusual complicating factor in determining reservoir pressures and temperatures and one that has not been adequately explored. In the basin, overburden above a reservoir can vary by as much as $5,000 \mathrm{ft}$ in a distance of $5 \mathrm{mi}$ or less, and, as a result, formation temperatures can vary as much as $100{ }^{\circ} \mathrm{F}$ from topography alone. The effects of these topographically induced temperature variations on gas-pressured reservoirs such as those in the Mesaverde could be very important because gas temperatures and pressures will be higher under mesas than under nearby canyons. If open pathways for fluid migration in the Mesaverde exist between the canyons and the mesas, formation pressures will tend to equilibrate between the canyons and the mesas.

The elevations of possible fluid discharge and recharge arcas for the Mesaverde in the basin range from approximately $6,000 \mathrm{ft}$ for the marine part of the Mesaverde along the Book Cliffs in the southwestern part of the basin to more than $10,000 \mathrm{ft}$ for the nonmarine part of the Mesaverde along the Grand Hogback. Reentrants cut in the hogback by modern streams are as low as 6,000 $\mathrm{ft}$, and the true elevations of possible recharge and discharge areas along the hogback may be much lower. If gas rather than water is the dominant pressuring fluid in the Mesaverde, then hydrodynamic principles may not adequately explain the reservoir conditions observed.

Based on hydrodynamic principles, three possible areas of overpressuring were identified in the Mesaverde of the Piceance basin by using a combination of available drill-stem test results and mud-weight data: on the northwestern flank of the Divide Creek anticline, along the Grand Hogback, and in the MWX area. The names and locations of possible overpressured wells are listed on table 2, as well as the mud weights used to drill the wells, the results of any drill-stem and perforation tests, and calculated potentiometric elevations. Mud weights of 8.3-10.2 $\mathrm{lb} / \mathrm{gal}$ (pounds per gallon) are needed to counterbalance normal hydrostatic pressures of formation water, depending on salinity. A study of mudweight data probably would identify only a fraction of the overpressured intervals in extremely tight formations such as the Mesaverde because formation fluids and gas do not leak into the well bore fast enough to be detected during drilling. On the other hand, drillers sometimes inadvertently use heavier-than-needed mud. A cutoff of $11-\mathrm{lb} / \mathrm{gal}$ mud was used to identify potentially overpressured areas; this cutoff allows for the possibility that the driller may have slightly overcompensated the mud weight.

The fluvial part of the Mesaverde is overpressured in two wells on the northwestern flank of the Divide Creck anticline, Sun Oil no. 1 Philpott and Mountain States no. 1 Starbuck (table 2). This overpressuring 
Table 2. Wells in which the Mesaverde appears to be overpressured

[Leaders (-), not measured]

\begin{tabular}{|c|c|c|c|c|c|}
\hline Well name & $\begin{array}{c}\text { Location } \\
\text { (sec. T.N., R.W.) }\end{array}$ & $\begin{array}{l}\text { Elevation } \\
\text { of top of hole } \\
\text { (in } f(e t)\end{array}$ & $\begin{array}{l}\text { Interval } \\
\text { tested } \\
\text { (in fea) }\end{array}$ & $\begin{array}{l}\text { Pressure } \\
\text { (lb/in.2) }\end{array}$ & $\begin{array}{c}\text { Fluid pressure } \\
\text { gradient } \\
\text { (lb/in. }{ }^{2} \text { ) }\end{array}$ \\
\hline Sun Oil no. 1 Philport................... & $36,7,92$ & 6,517 & $\begin{array}{l}2,255-2,280 \\
3,100-3,132\end{array}$ & $\begin{array}{l}1,280 \\
2,183\end{array}$ & $\begin{array}{l}0.56 \\
0.70\end{array}$ \\
\hline Mountain States no. 1 Starbuck..... & $25,7,92$ & 6,362 & $\begin{array}{l}3,675-3,750 \\
2,960-3,016\end{array}$ & $\begin{array}{c}1,914 \\
1,900-2,100\end{array}$ & $\begin{array}{c}0.51 \\
0.63-0.70\end{array}$ \\
\hline Mobil T-52-19G.......................... & $19,2,96$ & 6,885 & $\begin{array}{l}\text { Lower half } \\
\text { Mesaverde Formation }\end{array}$ & $(11.4 \mathrm{lb})^{1}$ & - \\
\hline Atlantic Richfield no. 1 North Rifle & 31,493 & 6,488 & $\begin{array}{l}\text { Lower half } \\
\text { Mesaverde Formation }\end{array}$ & $(11.6 \mathrm{lb})^{1}$ & - \\
\hline Maguire Oil no. 3 North Rifle....... & $10,5,93$ & 6,002 & $\begin{array}{c}\text { Fluvial } \\
\text { Mesaverde Formation }\end{array}$ & $(12.0 \mathrm{lb})^{1}$ & 一 \\
\hline 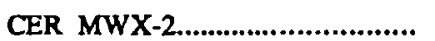 & $34,6,94$ & 5,374 & 8,300 & 6,598 & 0.80 \\
\hline
\end{tabular}

1 Pressure not measured; weight of mud used to drill hole is shown.

probably resulted from an artesian system that developed between the wells and outcrops of the Mesaverde on the crest of the Divide Creek anticline about 3-5 mi southeast of the wells. The wells were drilled in a valley at elevations of 6,343 and $6,517 \mathrm{ft}$, and the top of the Mesaverde was intersected at depths of 1,125 and 1,500 $\mathrm{ft}$. Maximum overpressuring was in the Sun Oil no. 1 Philpott well; mud weights as heavy as $14.5 \mathrm{lb}$ were used and fluid pressure gradients (initial shut-in pressure/depth) as high as $0.7 \mathrm{psi} / \mathrm{ft}$ were measured. The overpressured Mesaverde interval crops out at elevations of greater than $10,000 \mathrm{ft}$ on the crest of the anticline, and potentiometric elevations calculated in the wells (fig. 14) are all lower than this potential recharge area. The artesian hypothesis is supported by the abundance of relatively fresh water in many of the perforated fluvial Mesaverde intervals in the wells, in particular Sun Oil no. 1 Philpott. The fact that the marine part of the Mesaverde, which does not crop out on the anticline, is not overpressured in these wells also supports this hypothesis.

Heavy muds were used to drill through the Mesaverde in two wells along the hogback near Rifle, but no drill-stem or production data are available. This apparent overpressuring may also result from an artesian system, but the evidence is inconclusive. Although the Mesaverde crops out at elevations of greater than $9,000 \mathrm{ft}$ along the hogback, streams have cut narrow valleys as low as 6,000 $\mathrm{ft}$ that may decrease the maximum elevation of the artesian system. Using mud-weight data, maximum calculated potentiometric elevations in the two wells are about 9,500 ft for fresh formation water. Heavy muds were not used in other wells drilled along the hogback.

Unlike the overpressured areas discussed previously, overpressuring in the lower part of the Mesaverde in the MWX area cannot be explained by using an artesian model (table 2, fig. 14). In the MWX-2 well, mud weights as heavy as $15.3 \mathrm{lb} /$ gal were used (Mann, 1984). In all three MWX wells, overpressuring starts at a depth of about $5,600 \mathrm{ft}$, or about $1,900 \mathrm{ft}$ above the Rollins Sandstone Member, and increases steadily down to the Corcoran Member, the deepest unit penetrated. Because the wells were drilled at or near balance (Mann, 1984), the mud-weight data indicate pressure gradients as high as $0.8 \mathrm{psi} / \mathrm{ft}$ at the Corcoran level, and subsequent testing confirms these pressures. At MWX-2, calculated potentiometric elevations for the Corcoran are $12,273 \mathrm{ft}$ above sea level for fresh water and 9,492 ft for highly saline water. Present-day Corcoran outcrops have elevations of about $8,000 \mathrm{ft}$ along the Grand Hogback, north of the Coal Basin anticline and south of Newcastle (Donnell, 1962). These outcrops are too low for MWX formation pressures to be caused by a present-day artesian system.

Hcavy muds were used in the Mobil T-52-19G well, 33 mi north of the MWX site and a few miles west of the decpest part of the basin. A mud weight of $\mathbf{1 1 . 4}$ $\mathrm{lb} / \mathrm{gal}$ was used to drill through approximately the same 


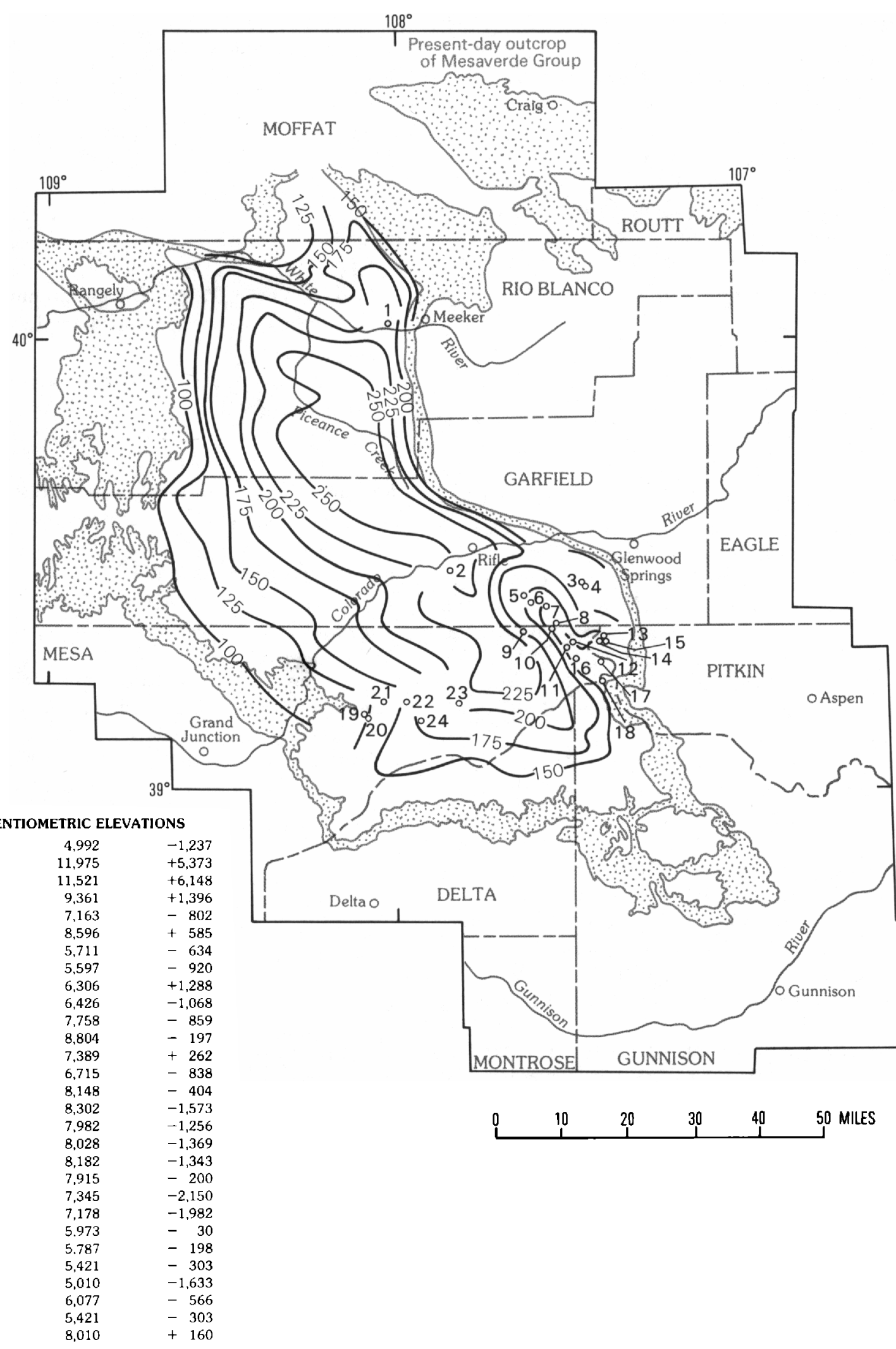

Figure 14. Potentiometric elevations calculated for Corcoran, Cozzette, and Rollins or Trout Creek Members . Contours of present-day formation temperatures at the Rollins-Trout Creek level (interval $25^{\circ} \mathrm{F}$ ) derived from thermal gradient map of Johnson and Nuccio (1986). Potentiometric elevation and amount elevation is above (+) or below (-) present-day elevation are shown (in feet) for each map location (indicated by number). Crcr, Corcoran Member; Czzt, Cozzette Member; RIns, Rollins or Trout Creek Member. 
stratigraphic interval that was overpressured at the MWX site. Unfortunately no pressure data were collected; hydraulic heads at the Rollins or Trout Creek level were calculated by using mud weights and range from $10,953 \mathrm{ft}$ for fresh water to $8,155 \mathrm{ft}$ for highly saline water. The area of possible ovcrpressuring does not appear to extend very far to the west, because pressure data for several wells drilled about $15 \mathrm{mi}$ west of the Mobil well indicate near normal pressures in the Mesaverde (Chancellor and Johnson, 1986). No data are available to indicate how far the area of overpressuring in the Mesaverde extends to the north, south, or east of the Piceance basin.

Most of the reliable pressure data available for the basin are from the Corcoran, Cozzette, and RollinsTrout Creek regressive cycles, but, although formation pressures of these units were studied in somewhat more detail, too few data are available to draw any major conclusions. Calculated potentiomctric elevations are plotted on figure 14, as well as approximate present-day temperatures for the top of the Rollins and Trout Creek derived from the geothermal gradient map of Jolnnson and Nuccio (1986). Most data are from three areas: the Divide Creek and Wolf Crcek anticlines, the Plateau Creek and Shire Gulch fields, and the MWX site. Although the data are too scattered to be contoured into a potentiometric surface map, some general observations can be made. On the Divide Creek and Wolf Creek anticlines, potentiometric elevations are $7,000-8,000 \mathrm{ft}$ above sea level. Potentiometric elevations decrease on the north flank of the anticline to approximately $5,500 \mathrm{ft}$, then rise as high as $9,361 \mathrm{ft}$ in the trough east of the anticline and to almost $12,000 \mathrm{ft}$ farther to the north at the MWX site. In the Divide Creek anticline area, both the Corcoran and the Cozzette approach true blanket reservoirs (pl. 1, view $D$ ) and should be relatively good conduits for fluid migration, particularly in light of the natural fracture systems that appear to be present. Sandstones of the Corcoran and Cozzette become discontinuous prior to reaching the MWX area. In the Plateau Creek and Shire Gulch fields, sandstones in the Corcoran and the Cozzette are also discontinuous. Potentiometric elevations in these fields are 5,000-6,000 $\mathrm{ft}$, except for one location just south of the field where the potentiometric elevation of the Rollins or Trout Creek is higher than $8,100 \mathrm{ft}$.

\section{ORIGIN OF THE MESAVERDE LOW-PERMEABILITY GAS ACCUMULATION}

The Mesaverde low-permeability gas accumulation in the Piceance basin is similar to low-pcrmeability gas-saturated sections in the central parts of many Rocky
Mountain Laramide basins. Large gas reserves are in low-permeability Cretaceous-age rocks in the San Juan basin of New Mexico and Colorado (Rice, 1983; Mcissner, 1984) and the greater Green River basin of Wyoming, Colorado, and Utah (Law and others, 1979, 1980; McPeck, 1981; Law, 1984) and in Triassic- through Crctaceous-age rocks in the Alberta Deep basin (Masters, 1979). A similar tight-gas accumulation of Cretaceous age may be in the Uinta basin of Utah and Colorado, but this deposit has not been extensively studied. In all these areas, the gas accumulations are in the structurally deepest areas of the basins, cut across lithologic boundaries, and lack easily definable conventional seals. In the Alberta Deep basin (Masters, 1979) and in the San Juan basin (Berry, 1959; Masters, 1979), the gas-water contact is the reverse of that in a conventional reservoir in that the gas accumulations are downdip from a zone of relatively fresh water. In the Piceance basin, the zone of fresh surface water invasion probably extends only 5-10 mi from outcrop for the marine regressive cycles and 10-15 mi from outcrop for the fluvial part of the Mesaverde, except in local areas such as the previously discussed overpressured zone on the north flank of the Divide Creek anticline. Lowpermeability gas accumulations are normally pressured to moderately underpressured except in the central areas of structurally decper basins such as the Piceance basin and the greater Green River basin where highly overpressured conditions have been encountered.

Tremendous amounts of water must have been driven out of structurally deep areas of these basins while the gas was accumulating. The expulsion of water was aided by thermogenic gas generation that created pore pressures greater than hydrostatic pressures (Meissner, 1978, 1984; McPeek, 1981; Law and Dickinson, 1985). The upward displacement of water by the expanding gas pocket is against the force of buoyancy, which in rocks having conventional permeabilities would have driven the gas upward instead of the formation water. Berry (1959) suggested that in the San Juan basin gas was trapped hydrodynamically by downdip water movement. Meissner (1984), however, believed that downdip water movement could not have trapped gas while the gas deposit was being created. Masters (1979) suggested that gas may be trapped by a relative permeability barrier and pointed out that in extremely tight rocks such as these the permeability of gas is only about 30 percent that of water at a water saturation of 40 percent, a typical water saturation in low-permeability Cretaceous reservoirs. This permeability difference would tend to trap gas and allow water to pass through. This phenomenon has been experimentally demonstrated by Gies (1984), and, if this model is correct, basin-center gas deposits will only be found in rocks having extremely low permeabilities. 
The relative permeability seals on these accumulations are probably imperfect, and without a continuous supply of gas the accumulation will begin to decrease in size (Meissner, 1978; Gies, 1982, 1984; Welte and others, 1982). In a complex section of interbedded and lenticular lithologies such as the Mesaverde Group in the Piceance basin, the rate of leakage is difficult to assess. This leakage does indicate that more gas has been generated in the basin than can now be accounted for.

Much of the gas in Rocky Mountain lowpermeability Cretaceous reservoirs probably was derived from interbedded coals and carbonaccous shales. Although temperatures in all of these basins have declined because of both the removal of overburden and declining thermal gradients, the interbedded coals and carbonaceous shales are probably still generating significant quantities of thermal gas in the deeper, hotter areas of the basins. This present-day gas generation may be responsible for the abnormal formation pressures in the highly overpressured areas of the greater Green River basin and the Piceance basin (Law and others, 1979, 1980; Law and Spencer, 1981; Spencer and Law, 1981; Law and Smith, 1983; Law, 1984). Law (1984) believed that significant present-day thermal gas generation in the Green River basin begins at an uncorrected bottom-hole temperature of about $180{ }^{\circ} \mathrm{F}$ and a coal rank (as measured by vitrinite reflectance) of about 0.80 percent.

The subsurface temperature at which overpressuring is encountered can be affected by recent erosion. Overpressuring on the Pinedale anticline of the Green River basin begins at an uncorrected bottom-hole temperature of about $150^{\circ} \mathrm{F}$ and a vitrinite reflectance of 0.74 percent (Law, 1984). Law (1984, p. 487) attributed these lower values to fairly recent movement on the anticline: "Prior to the development of the Pinedale anticline, the present level of organic maturity was achieved and an overpressured condition had developed due to the generation of gas. Uplift and erosion in the vicinity of the anticline displaced the overpressured rocks from a hotter, thermal equilibrium surface into a cooler, disequilibrium environment." $\mathrm{He}$ defined a disequilibrium environment as one in which formation temperatures have declined from maximum.

Variations in organic richness can also affect the amount of overpressuring. At a subsurface temperature of $180^{\circ} \mathrm{F}$, the increase in pressure gradient is very slight if the formation is organic poor (Law, 1984). At the tops of organic-rich sequences in the Green River basin (Law, 1984) and at the MWX site in the Piceance basin (Mann, 1984), pressure gradients typically increase sharply. At the MWX site, such an increase is at the top of the Cameo-Fairfield coal zone. Thus far, in the area of the central part of the Piceance basin studied by Chancellor and Johnson (1986), only slightly underpressured to very slightly overpressured conditions have been documented and subsurface temperatures as high as $242^{\circ} \mathrm{F}$ have been measured. The sparseness of organic material in the upper part of the Mesaverde in this area is cited by Chancellor and Johnson as a possible contributing factor.

The rate of gas loss can also affect subsurface pressures. Low-permeability reservoirs are very stress sensitive (Spencer, 1983), and, if confining stress is lessened during uplift and erosion, pores and pore throats enlarge and microfractures open and, as a result, permeabilities increase (Law and Dickinson, 1985). Because all Laramide basins have been uplifted and eroded to some extent during the last 10 m.y., permeabilities have probably increased significantly. As a result, the invasion of surface water and the escape of gas to the surface now occur at higher rates than when the basins were at maximum burial depths.

The maximum migration distance for gas generated by interbedded coals and carbonaceous shales in tight formations is controversial. Rice (1983) and Law (1984) argued that extremely low permeabilities generally limit migration distances. Meissner (1984), on the other hand, believed that in the San Juan basin a combination of free gas flow enhanced by strong pressure gradients and diffusion results in much greater migration distances. Using a vitrinite reflectance of 0.73 as the threshold of significant thermal gas generation, Meissner pointed out that gas is produced from the Upper Cretaceous Fruitland Formation in areas in which it is thermally immature. Some of these gas fields are more than 30 lateral miles from areas in which the Fruitland is mature. In the Piceance basin, gas and minor oil have been produced from the Cameo-Fairfield coal zone and units overlying the Cameo-Fairfield on the thermally immature White River dome (figs. 3, 8, 9). Unlike the Pinedale anticline in the Green River basin, no significant movement has occurred on the White River dome since near the end of the Eocene. Because considerable water has also been encountered in the Mesaverde on the Whitc River dome, the Mesaverde in this area may be within the transition gas- and waterbearing zone rather than in the gas-bearing zone. Nevertheless, cither gas has migrated laterally into the structure from a considerable distance or gas has migrated vertically upward at least $1,000-2,000 \mathrm{ft}$ from deeper, more thermally mature strata. Such migration may have been aided by open natural fracture systems in which permeabilities are greater than the surrounding rock and gas is driven upward by buoyancy.

Limited data in the Piceance basin suggest that both the underlying Mancos Shale and the interbedded coals and carbonaceous shales may have been important sources for Mesaverde gas, and at the MWX site both sources appear to have contributed to the Mesaverde gas. Isotopic analyses of gas from the MWX site (D.D. Rice, 
written commun. to Allan Sattler, Sandia National Laboratories, 1982) suggest that gas in the coal beds originated within the coal beds themselves, whereas gas in the Corcoran and Cozzette Members was derived in part from the thermal cracking of oil that originated in the underlying Mancos Shale. The latter hypothesis is supported by the discovery of a burned-out oil zone in the Cozzette by C.W. Spencer (oral commun., 1985). Such burned-out zones are thought to form by the thermal cracking of oil and are found in formations that have been heated to temperatures beyond the stability range of oil.

It is impossible at this time to quantitatively assess the amount of methane contributed by the Mancos Shale to the Mesaverde gas deposit. Studies of the overlying Mesaverde indicate that the Mancos is thermally mature enough throughout most of the basin to have generated hydrocarbons and is beyond the stability range of oil throughout much of the central part of the basin. Few analyses indicating the type and thermal maturity of the organic matter of the Mancos Shale are available, and no estimates have been made of either the amount of hydrocarbons in the Mancos or the amount of hydrocarbons that may have been expelled. Meissner and others (1984) suggested that some intervals in the Man$\cos$ Shale and other similar shale sequences of similar age in the Rocky Mountains contain $0.7-4.0$ percent total organic carbon, amounts high enough to consider the Mancos a potentially significant source of hydrocarbons in the basin, particularly in light of its great thickness. The Mancos probably contains a mixture of hydrogenrich marine organic matter, believed to generate mostly oil, and hydrogen-poor terrestrial organic matter, believed to generate mostly gas. As previously mentioned, oil breaks down into mostly methane when excessively heated.

It is easier to assess the amount of methane generated by coal zones in the basin such as the CameoFairfield. Methane is generated from coals first very early in their burial history by biogenic processes and again later in their history by thermal cracking. The amount of thermal gas generated by coals is directly related to rank. Coal rank is determined by using several different methods including British thermal units per ton (Btu/ton), percent volatile matter $(V M)$, and percent vitrinite reflectance $(R o)$. Meissner (1984) recently summarized the relationship between these various methods. Table 3 shows the volumes of methane believed to be generated by coal of various ranks, as determined by vitrinite reflectance (Meissner, 1984).

A map showing the total volume of gas generated by the Cameo-Fairfield coal zone in millions of cubic feet per acre (fig. 15) was constructed by overlaying the coal-thickness map on the coal-rank map and using the data shown in table 3 to convert coal rank into amount of
Table 3. Volumes of methane produced by coals of various ranks

[Coal rank is shown as vitrinite reflectance or percent volatile material. Data from Meissner (1984); calculated using method of Juntgen and Karweil (1966)]

\begin{tabular}{lccr}
\hline Coal rank & $\left(\mathrm{cm}^{3 / g}\right)$ & $\begin{array}{c}\text { Amount of methane produced } \\
\left(\mathrm{f}^{3} \text { hon }\right)\end{array}$ & \multicolumn{3}{c}{$\left(\mathrm{ft}^{3} / \mathrm{acre}-\mathrm{f}\right)$} \\
\hline 3 & \multicolumn{3}{c}{} \\
37.8 & Start of methane generation \\
35 & 6.7 & 215 & 391,027 \\
30 & 28.5 & 912 & $1.662 \times 10^{6}$ \\
25 & 54.3 & 1,737 & $3.165 \times 10^{6}$ \\
20 & 85.8 & 2,747 & $5.040 \times 10^{6}$ \\
15 & 126.5 & 4,049 & $7.377 \times 10^{6}$ \\
10 & 183.9 & 5,883 & $10.719 \times 10^{6}$ \\
5 & 281.9 & 9,019 & $16.434 \times 10^{6}$ \\
4 & 313.4 & 10,209 & $18.274 \times 10^{6}$ \\
& & & \\
\hline
\end{tabular}

methane generated. Generated gas ranges from zero in areas where vitrinite reflectance is less than 0.73 to more than 600 million cubic feet per acre (MMCF/acre) near the semianthracitic areas of the basin; about $462 \mathrm{MMCF} /$ acre of gas were generated by the coals at the MWX site. Measurements of the gas absorption capacity of coals made by Eddy and others (1982) indicate that approximately $88 \mathrm{MMCF} / \mathrm{acre}$ of gas is stored in the coals of the Cameo-Fairfield coal zone at MWX. Obviously, a considerable amount of methane probably was generated by the associated carbonaceous shales; however, at this time, a reasonable estimate of this amount cannot be made.

\section{GEOLOGIC HISTORY OF THE PICEANCE BASIN AS RELATED TO RESERVOIR DISTRIBUTION AND GAS GENERATION}

A general geologic history of the Piceance basin has been reconstructed in order to define the geologic framework in which the Mesaverde tight-gas sand accumulation formed. The model presented in this report is similar in many respects to the general model proposed by Law and Dickinson (1985) for all lowpermeability gas accumulations, but much specific information pertinent to the Piceance basin is included.

Johnson and Nuccio (1986) recently reconstructed the subsidence and thermal history of the basin in an attempt to explain coal-rank variations in the basin, and much of their information is used here. Their attempt was only partly successful, because of a lack of reliable present-day temperature data for the basin and because of uncertainties as to extrapolation of present-day thermal gradients into the past. Schematic cross sections drawn parallel with and perpendicular to the trough of the basin (Johnson and Nuccio, 1986) (figs. 16, 17) 

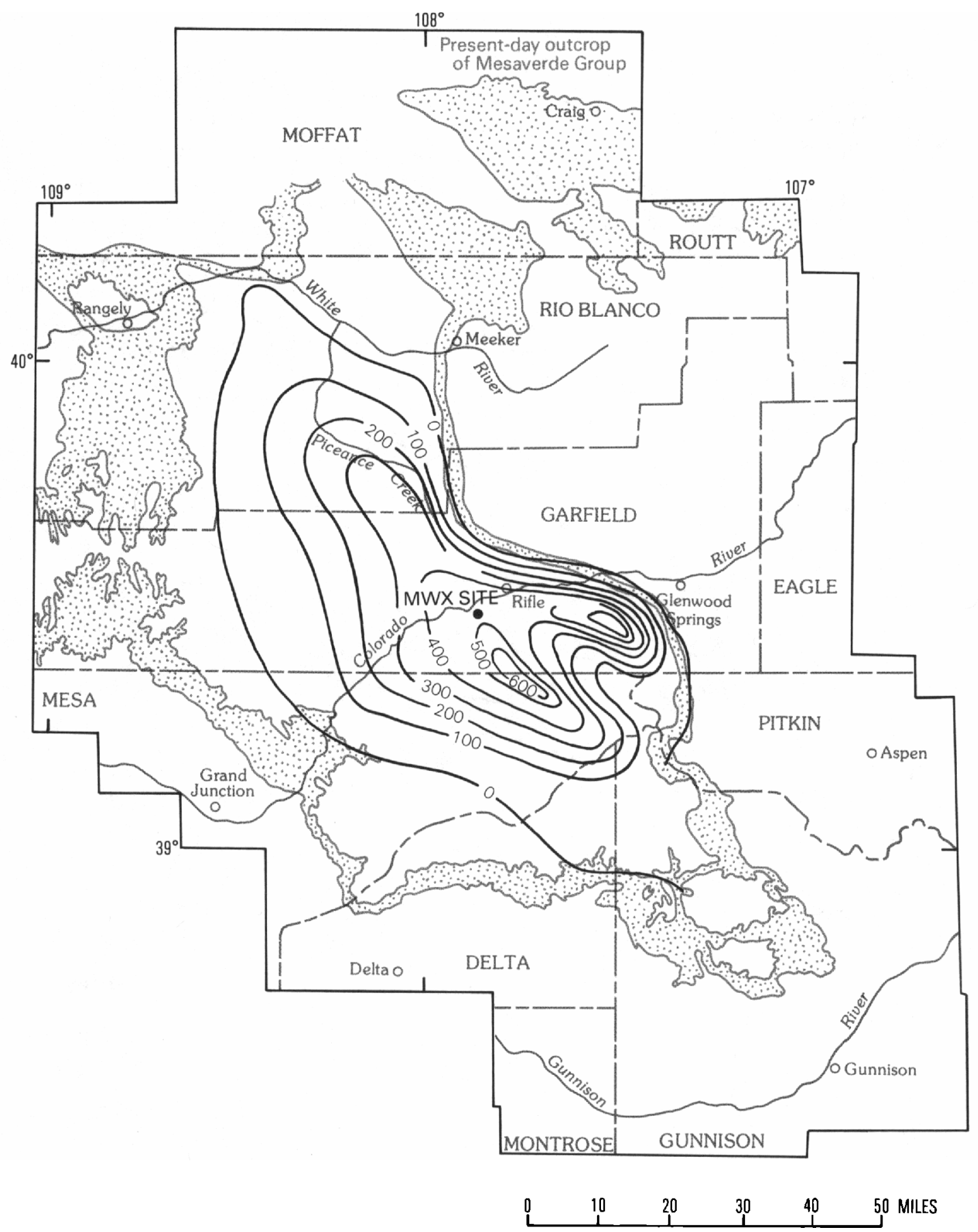

Figure 15. Total calculated volume of methane produced by Cameo-Fairfield coal zone. Map constructed by overlaying coal-thickness and coal-rank maps (figs. 7,8 ) and using data of table 3 to convert coal rank into volume of methane produced. Contour interval 100 million cubic feet per acre.

illustrate the general development of the basin through time and show the geologic history of the surrounding uplifts as it pertains to the geologic history of the Mesaverde Group. On the flanks of some of these Laramide uplifts, the Mesaverde was exposed even prior to the end of Mesaverde deposition; these areas almost certainly acted as recharge and discharge areas for fluids in the Piceance basin and strongly influenced both hydrodynamics and diagenesis in the basin through time.

Near the end of the Cretaceous-Tertiary hiatus, the Mesaverde was beveled close to present-day thicknesses. The depth to the top of the Rollins or Trout Creek Sandstone Members and approximate formation temperatures at that depth, based on present-day 

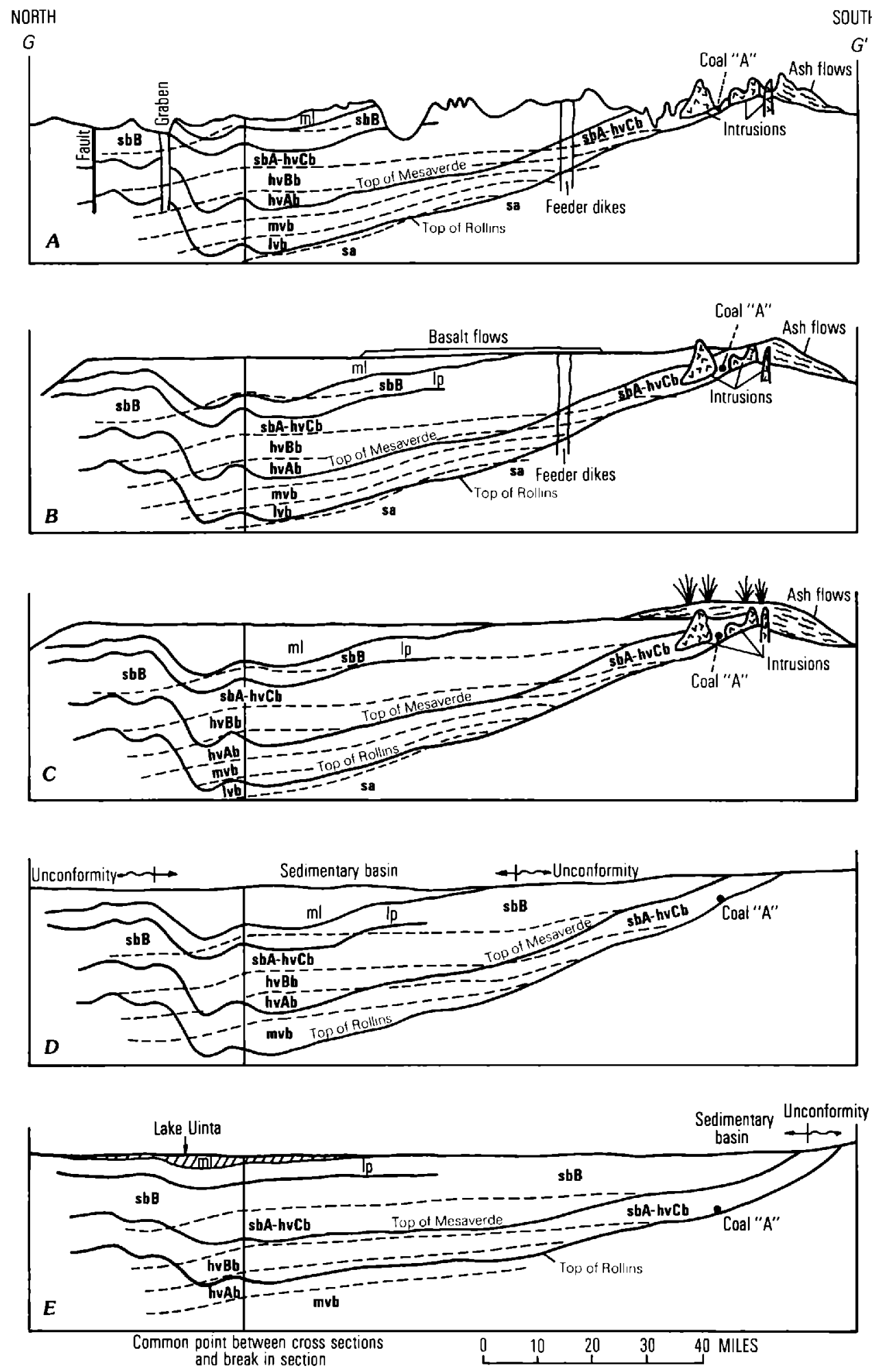

Figure 16. 'Schematic cross section drawn along trough of basin showing model for development of Piceance basin. $A$, Holocene or present; $B$, early Miocene (24-11 m.y. ago); $C$, middle Oligocene (34-29 m.y. ago); $D$, end of Eocene (37.5 m.y. ago); $E$, middle Eocene (46 m.y. ago). Coal rank symbols: sBa-hvCb, subituminous $A$-high volatile $C$ bituminous; hvBb, high-volatile B bituminous; hvAb, high-volatile $A$ bituminous; mvb, medium-volatile bituminous; lvb, low-volatile bituminous; sa, semianthracite. Dashed lines separate coal rank areas; $\mathrm{ml}$, top of Mahogany zone; Ip, base of Long Point bed. Vertical exaggeration $\times 10$. Line of section shown on figure 3. From Johnson and Nuccio (1986). 
thermal gradients (Johnson and Nuccio, 1986), are shown on figure 18. By the end of the hiatus, subsidence in the basin had ceased and regional uplift or tilting had begun. Throughout the basin the Mesaverde was exposed to surface weathering. The amount of uplift and beveling
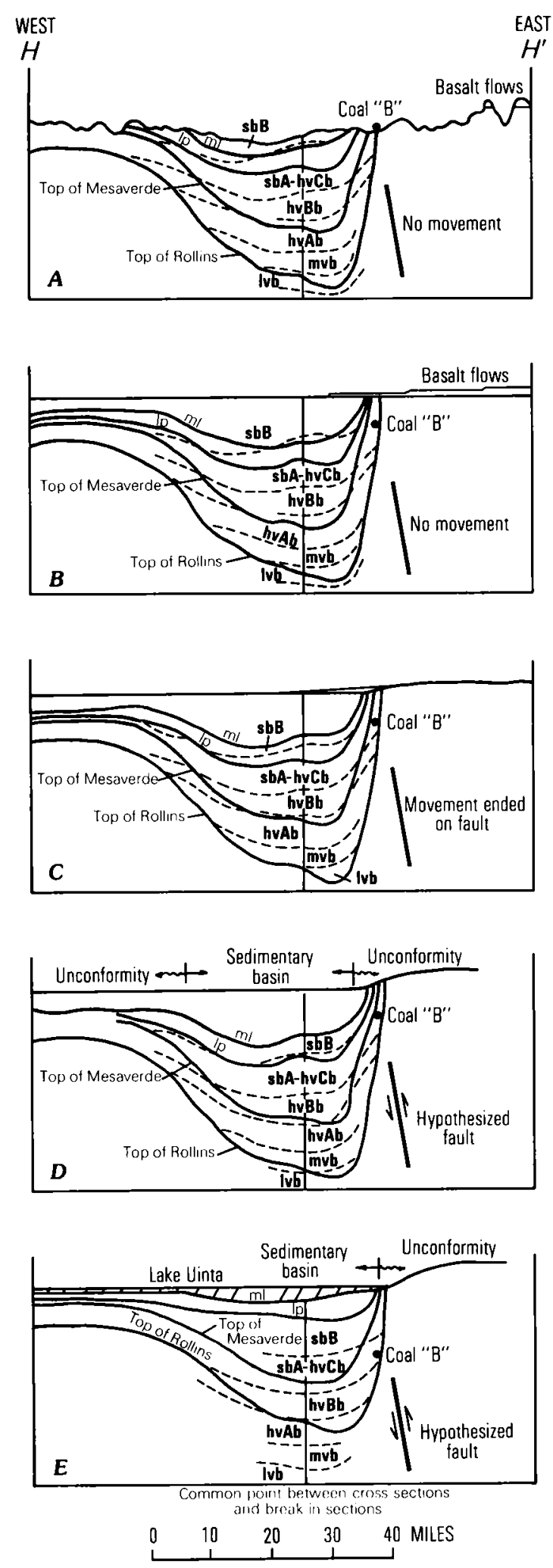

during this period increased from east to west across the basin, and increasingly older Mesaverde sediments were exposed to surface weathering toward the Douglas Creek arch. Several other surrounding Laramide uplifts were also active during this period. Southeast of the basin, the entire Mesaverde section was eroded off the top of the Sawatch uplift, and the Mesaverde may have been eroded off the tops of the White River, Uncompahgre, and Uinta uplifts as well. Mesaverde rocks on the flanks of these uplifts during this period were probably as much as several thousand feet higher than in the adjacent basin.

Beveling exposed all stratigraphic levels in the Mesaverde somewhere within the basin or on the flanks of one of the surrounding uplifts. Although this beveled surface would have promoted the free flow of fluids throughout the entire Mesaverde section, weathering greatly affected the rocks immediately below the unconformity surface (Johnson and May, 1978, 1980; Hansley and Johnson, 1980). The general lack of compaction of Mesaverde sediments prior to the onset of diagenesis is evidence that considerable diagenesis occurred during this interval. The beveled Mesaverde would have also produced an ideal situation for surface-water recharge and formation-water discharge. Artesian systems, similar to the present-day system locally on the north flank of the Divide Creek anticline, probably developed in the Mesaverde adjacent to these topographically high uplifts.

Although maximum temperatures in the Mesaverde in the deepest part of the basin were probably not high enough to generate significant thermal gas, some shallow biogenic methane may have been produced. Temperatures in the underlying Mancos Shale, however, probably were high enough to produce hydrocarbons. Maximum burial depths for the lower part of the Mancos Shale during this period were approximately $10,000 \mathrm{ft}$ in the deepest part of the basin. Using present-day thermal gradients, such depths would translate into formation temperatures of $225-250^{\circ} \mathrm{F}$, temperatures high enough for thermal hydrocarbon generation. To what extent these hydrocarbons migrated into the Mesaverde during this period is not known.

During the early to middle Paleocene, sediments began to bury the Cretaceous-Tertiary unconformity

Figure 17. Schematic cross section drawn perpendicular to trough of basin showing model for development of Piceance basin. $A$, Holocene or present; $B$, early Miocene (24-11 m.y. ago); $C$, middle Oligocene (34-29 m.y. ago); $D$, end of Eocene (37.5 m.y. ago); $E$, middle Eocene (46 m.y. ago). Coal rank symbols: sBa-hvCb, subituminous A-high volatile $\mathrm{C}$ bituminous; hvBb, high-volatile $B$ bituminous; hvAb, highvolatile $A$ bituminous; mvb, medium-volatile bituminous; Ivb, low-volatile bituminous. Dashed lines separate coal rank areas; $\mathrm{ml}$, top of Mahogany zone; Ip, base of Long Point bed. Vertical exaggeration $\times 10$. Line of section shown on figure 3 . From Johnson and Nuccio (1986). 

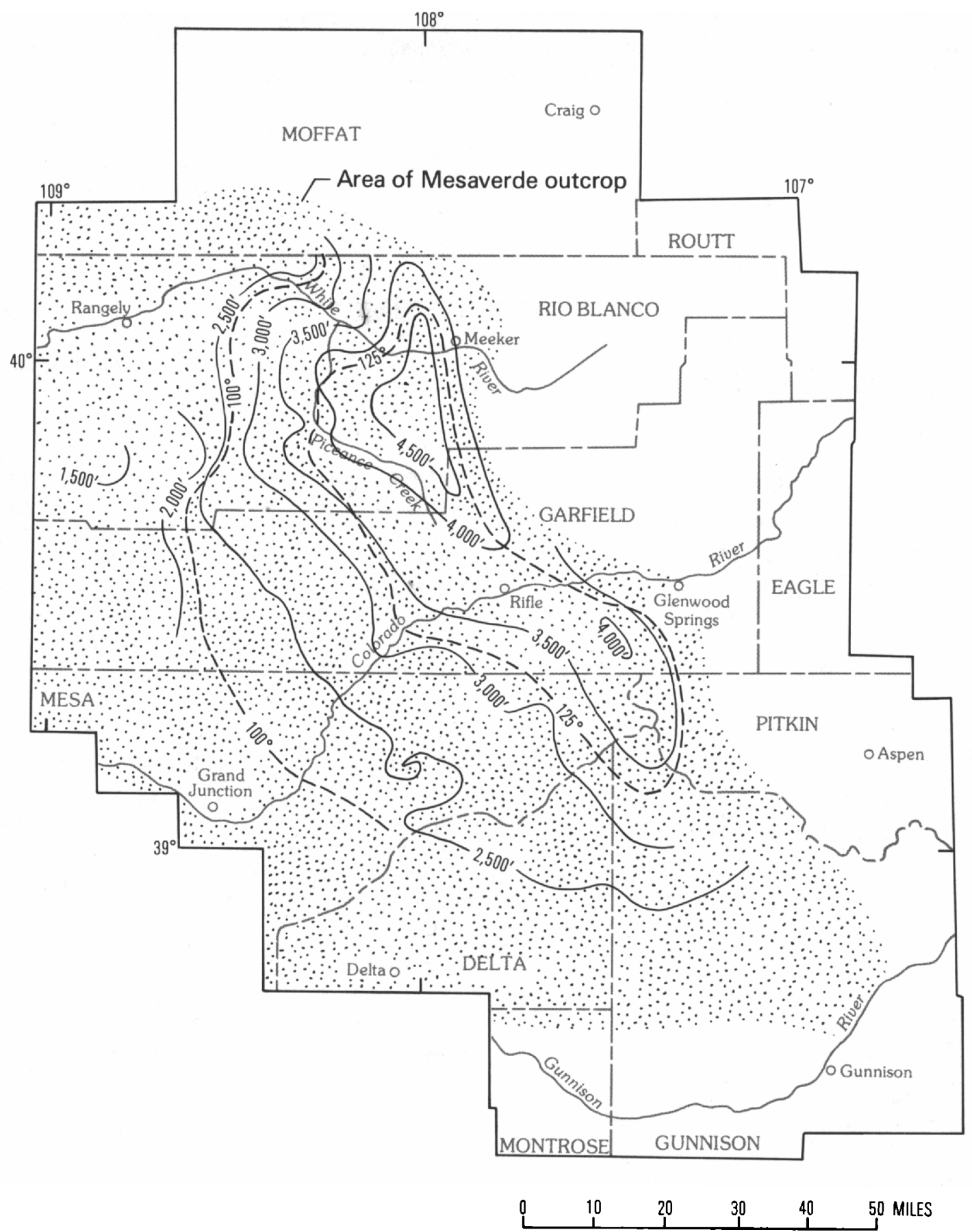

Figure 18. Area of Mesaverde outcrop in Piceance basin near end of Cretaceous-Tertiary hiatus. Isopachs (solid lines, interval $500 \mathrm{ft}$ ) of present-day Rollins or Trout Creek to Cretaceous-Tertiary unconformity interval. Isotherms (dashed lines, interval $25^{\circ} \mathrm{F}$ ) of temperatures at the Rollins or Trout Creek level near the end of the unconformity interval; calculated using present-day thermal gradients of Johnson and Nuccio (1986).

near the structural trough of the basin (Johnson and Keighin, 1981; Johnson, 1985b). Figure 19 shows the Piceance basin immediately prior to deposition of the lower Eocene Long Point Bed of the Green River Formation. By Long Point time, the area of sedimentation had gradually expanded such that the last remaining outcrop of Mesaverde on the Douglas Creek arch was buried and the Piceance sedimentary basin merged with the Uinta sedimentary basin to the west to form one large sedimentary basin. In a sense, this merger marks the end of the hiatus and Mesaverde beveling in the basin, although most of the unconformable surface in the basin was buried by the end of the Paleocene. At the time of the merger, the Mesaverde was still exposed 

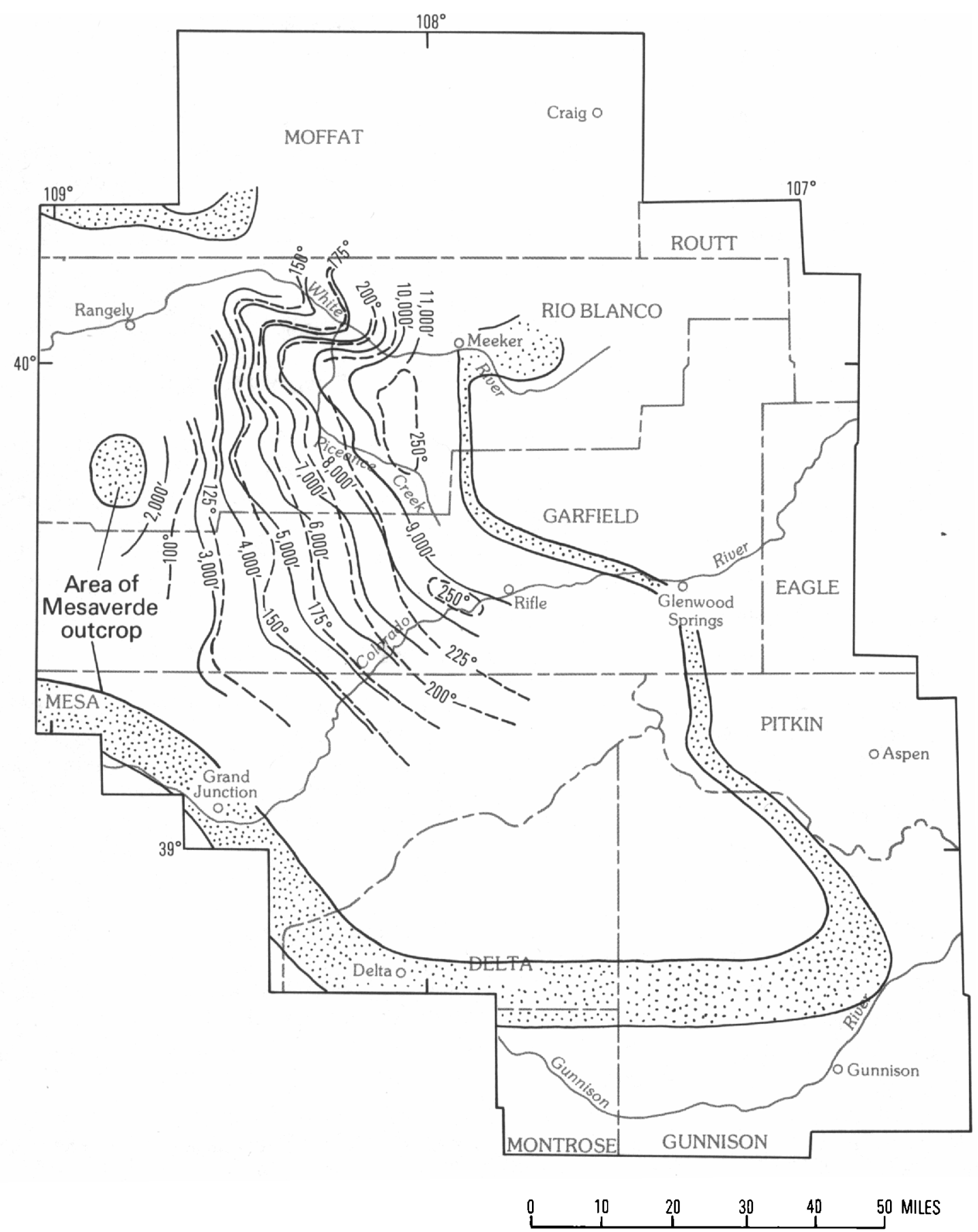

Figure 19. Area of Mesaverde outcrop in Piceance basin immediately prior to deposition of lower Eocene Long Point Bed. Isopachs (solid lines, interval 1,000 ft) of present-day Rollins or Trout Creek to Long Point Bed interval. Isotherms (dashed lines, interval $25^{\circ} \mathrm{F}$ ) of temperatures at the Rollins or Trout Creek level during Long Point time calculated using present-day thermal gradients of Johnson and Nuccio (1986).

along a broad band of outcrops on the Clanks of the surrounding uplifts. These outcrops probably were still as high as several thousand feet above the floor of the adjacent sedimentary basin, and artesian-driven overpressured systems may have continued near these uplifts.

A large saline lake in the basin at this time may have influenced diagenesis in the Mesaverde, at least near the basin margins. During the early Eocene, Lake Uinta rapidly transgressed to within a few miles of many of the surrounding uplifts during a major transgression called the Long Point transgression (Johnson, 1984). After the Long Point transgression, the salinity of Lake Uinta gradually increased, and extensive saline deposits eventually were precipitated. Saline water may have 
leaked into the Mesaverde in areas such as the Douglas Creek arch where the Tertiary sedimentary cover was thin. Somewhat later in the history of Lake Uinta, during deposition of the Mahogany oil-shale zone, Lake Uinta deepened significantly and may have transgressed far enough to cover part of the surrounding uplifts, much as Lake Bonneville in Utah transgressed up the flanks of surrounding uplifts during periods of the Pleistocene. During this period, saline lake water may have directly overlain exposed Mesaverde recharge areas (fig. 17E). The zeolite analcime is a diagenetic phase in the Mesaverde in some basin margin areas (Hansley and Johnson, 1980; Heinz, 1984). Analcime is a common zeolite in alkali lake sediments, including Lake Uinta sediments, but is extremely rare as a diagenetic phase in coastalplain sediments such as the Mesaverde.

By early Eocene Long Point time, the lower part of the Mesaverde in the deepest part of the basin probably was buried deeply enough to generate hydrocarbons. Along the structural trough of the basin southwest of Meeker, depths to the top of the Mesaverde were as much as $6,000 \mathrm{ft}$ and depths to the top of the Rollins or Trout Creek were greater than 11,000 ft (fig. 17E). Maximum temperatures at the Rollins or Trout Creek level, based on present geothermal gradients, were higher than $250{ }^{\circ} \mathrm{F}$, well within the range of significant thermal gas generation. Regional diagenesis must have reduced permeabilities prior to the onset of significant gas generation. Figures $16 E$ and $17 E$ show the approximate rank of coals in the Mesaverde somewhat later, during deposition of the Mahogany zone, but can be used in a general way for the Long Point time period as well. The cross sections suggest that, at least in deeper parts of the basin, the Mesaverde was thermally mature enough to generate hydrocarbons.

Active generation of thermal gas by coals in the Mesaverde would have eventually saturated available pore space within the coals and caused gas to leak into the adjacent shales, siltstones, and sandstones. Although the first gas expelled would have dissolved in the formation water, free gas bubbles eventually would have formed. Permeabilities in the adjacent sandstones must have been very low by this time; otherwise, more persistent units such as the Rollins and Trout Creek Members would have acted as conduits to the surface and most of the gas would have escaped. Because of the greater permeability of tight rocks to water as compared to gas, formation water was driven updip in front of the expanding gas pocket instead of the other way around. This process was probably not totally effective, and to some extent normal buoyancy forces were probably important. In rocks having open natural fractures or more normal permeabilities, buoyancy forces will cause gas rather than formation water to migrate updip; if such buoyancy forces had dominated in rocks of the Mesaverde, the gas pocket would not have formed.

The large net expansion of volume that results when methane is generated from coal or coaly material increases formation pressures such that they are substantially greater than hydrostatic pressures. These high pressures helped expel formation water from the expanding gas pocket. A combination of updip migration of gas through pores and natural fractures and the release of gas from gas-charged formation waters as the water moved updip into rocks having lower pressures may partly explain the accumulation of gas in lowpermeability reservoirs on the thermally immature White River dome. Meissner (1984) suggested that highly reactive water released by coals during maturation may be the primary cause of the tightly cemented nature of the adjacent sandstones; however, diagenesis in the Piceance basin was also aided by surface weathering during the Cretaceous-Tertiary hiatus and by the free flow of water between the surface and deeper parts of the basin.

At the end of the Laramide orogeny, about 40 m.y. ago, basin subsidence ceased (figs. 16B-D, 17B-D, 20). Between $40 \mathrm{~m}$.y. ago and about $10 \mathrm{~m} . \mathrm{y}$. ago, when the Colorado River system began to cut deep canyons, little structural movement or sedimentation occurred in most of the basin. The late Cenozoic tectonism that affected many areas in Colorado and Utah apparently did not greatly affect the Piceance basin. Faulting on the Douglas Creek arch and along the White River is probably the most significant post-Laramide tectonism in the basin, and faults in both areas postdate Green River deposition. The present-day course of the White River follows the grabens developed in the area and any faulting that influenced the course of the modern White River probably occurred after the Laramide orogeny (Johnson and Nuccio, 1986).

During late Eocene to early Oligocene time, an erosion surface developed across the entire basin (figs. $16 D, 17 D)$. This surface is similar to late Eocene erosion surfaces that developed in other parts of the Rocky Mountains (Epis and Chapin, 1975). Remnants of this surface are still preserved beneath 9.7-million-year-old basalts in the basin at a present-day elevation of about $10,000 \mathrm{ft}$ (Marvin and others, 1966). The amount of section removed is clearly a function of basin subsidence trends and varies from little or none in the center of the basin to 2,000-3,000 $\mathrm{ft}$ along the slowly subsiding margins of the basin. The almost flat, present-day erosion surface indicates that erosion continued after basin subsidence ceased. The surface probably started to develop around the margins of the basin during the latest stages of basin subsidence during the late Eocene and spread to cover the entire basin after subsidence ceased. 


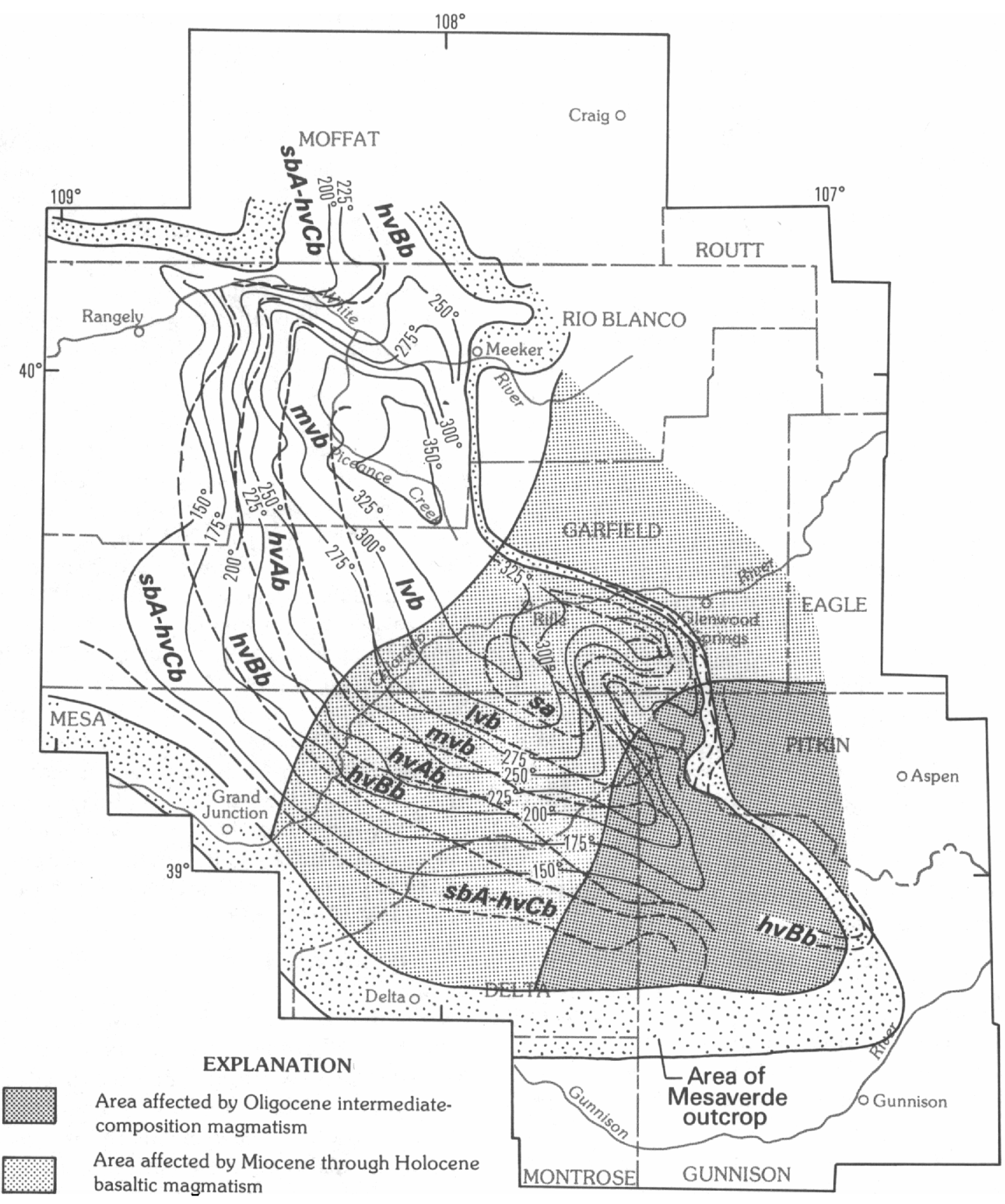

basaltic magmatism

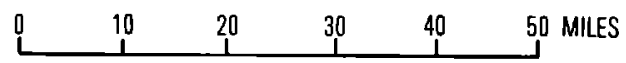

Figure 20. Area of Mesaverde outcrop in Piceance basin between end of Laramide orogeny and about 10 m.y. ago, at which time the Colorado River canyon system began to form. Dashed lines indicate boundaries between present-day coal rank areas near base of Cameo-Fairfield coal zone. Coal rank symbols: $\mathrm{sBa}-\mathrm{hvCb}$, subituminous A-high volatile $\mathrm{C}$ bituminous; hvBb, high-volatile $\mathrm{B}$ bituminous; hvAb, high-volatile A bituminous; mvb, medium-volatile bituminous; Ivb, low-volatile bituminous; sa, semianthracite. Isotherms (solid lines; interval, $25^{\circ} \mathrm{F}$ ) calculated using present-day geothermal gradients of Johnson and Nuccio (1986).

By 24 m.y. ago, the White River uplift east of the basin was beveled to about the same level as the erosion surface in the Piceance basin surface. The erosion surface on the uplift is covered by basalts that are from
24 to 8 m.y. old (Larson and others, 1975). The artesian system that existed along the flank of the uplift was probably destroyed, and Mesaverde outcrops along the Uncompahgre, Uinta, and Sawatch uplifts were probably 
reduced to about the same elcvation as in the adjacent basin. Only along the southern margin of the basin is there evidence that during this period Mesaverde outcrops were significantly higher than the erosion surface beneath the basalts in the Piceance basin. Even today the Mesaverde crops out at elevations of almost $12,000 \mathrm{ft}$ adjacent to Oligocene-age plutons in this area, and, prior to the recent period of crosion, even higher outcrops certainly were present and an artesian system may have been maintained.

Although the Piceance basin appears to have escaped extensive middle and late Cenozoic tectonism, magmatism almost continuously affected the southern part of the basin during this period. Shallow intrusions of intermediate composition were emplaced throughout the southern part of the basin from about 34 to 29 m.y. ago (figs. 16C, 20), and several of these plutons vented on the surface and probably covered the entire area with a sheet of volcanic ash. The ash partly filled the ancestral Gunnison River valley along the southern margin of the basin (fig. 16C), where it is still preserved (Hunt, 1969). These intrusions must have towered over the relatively flat, beveled plain to the north. Today exposed plutons form peaks that reach elevations of greater than $14,000 \mathrm{ft}$, and the plutons once must have been covered by several thousand feet of domed sediments and volcanic ash.

About 24 m.y. ago, basaltic magmatism began and continued until almost to the present (Giegengack, 1962; Larson and others, 1975). Basalts as old as 24 m.y. cover the late Eocene-early Oligocene erosion surface of the White River uplift just east of the basin (fig. 17B). By about 10 m.y. ago, when the Colorado River system began to cut deep canyons through the basin, the entire central part of the Piceance basin was covered by thick basalt flows (fig. 16B). Several basalt flows are on old cut terrace levels in the Colorado River canyon and hence postdate the onset of downcutting. The youngest flow was extruded on the floor of the modern Colorado River canyon just east of the basin about 4,150 years B.P. (Giegengack, 1962). The northern half of the basin does not appear to have been affected by igneous activity.

The maximum thickness of sediments from the top of the Rollins or Trout Creek Members to the late Eocene-early Oligocene erosion surface is approximately $16,000 \mathrm{ft}$. This thickness is probably a good approximation of overburden on the Rollins or Trout Creek Sandstone Members in the basin during this time interval except in the southern part of the basin where the erosion surface was disrupted by Oligocene plutonism and covered by an unknown thickness of ash. Using this thickness and present-day thermal gradients, temperatures at the Rollins or Trout Creek level were calculated (fig. 20). These temperatures are as high as $350{ }^{\circ} \mathrm{F}$, a temperature generally regarded as being beyond the stability range of oil. Any oil that may have accumulated in the Mesaverde in the deeper, hotter areas of the basin, such as the oil once present in the Cozzette Member at the MWX site, probably began to break down during this long interval. This breakdown of oil into methane and other gaseous hydrocarbons resulted in a major increase in volume that helped keep formation pressures high and expanded the size of the gas accumulation. Oil remained stable in the shallower, cooler areas of the basin and is still produced in limited quantities on the Douglas Creek arch and the White River dome. The continuous metamorphism of coals and carbonaceous shales in the Mesaverde also contributed to the expansion of the gas accumulation throughout the period.

The boundaries between present-day coal-rank zones in the overlying Cameo-Fairfield coal zone approximately parallel isotherms in the northern twothirds of the basin (fig. 20). The high volatile C-high volatile $\mathrm{B}$ bituminous (hvCb-hvBb) boundary approximately parallels the $200-225^{\circ} \mathrm{F}$ isotherms, the high volatile B-high volatile A (hvBb-hvAb) bituminous boundary approximately parallels the $225^{\circ} \mathrm{F}$ isotherm, and the high volatile A-medium volatile bituminous (hvAb-mvb) boundary approximately parallels the $250-275^{\circ} \mathrm{F}$ isotherms. Toward the southern margin of the basin, the coal-rank zones are at increasingly lower isotherms (figs. 16B, 20). Present-day contacts between coal-rank zones rise about $5,500 \mathrm{ft}$ in the area between the Colorado River and the southern margin of the basin, and in this area thermal gradients may have been higher as a result of magmatism.

Bostick and Freeman (1984) found that presentday coal ranks at the MWX site can be modeled by using present-day thermal gradients; however, the MWX site is near the northern limit of igneous activity and may not have been strongly affected. Pulses of heat from intrusive and extrusive activity probably increased the rate of coal and carbonaceous shale metamorphism as well as the rate of breakdown of oil into gaseous hydrocarbons. These pulses probably were regional in extent rather than confined to a limited area around individual plutons because coal-rank zones are approximately parallel with regional basin structure, even along the highly intruded southern margin of the basin (Johnson and Nuccio, 1986), and around individual plutons contact metamorphic effects are relatively limited. Thermal gradients during these pulses cannot be modeled at this time using present-day coal ranks because both time and temperature affect coal ranks: thus, deviation from the expected coal rank based on present-day thermal gradients could result from either a relatively modest increase in thermal gradient for an extended period of time or a much larger increase in thermal gradient for a relatively short period of time-or a combination of both. 
Other factors also may have contributed to the regional rise of coal-rank zones to progressively shallower levels toward the southern margin of the basin. A thick layer of ash from venting Oligocene plutons may once have covered much of this area. Although no ash remains, it is unlikely that such a major intrusive and extrusive event could occur so close to the southern part of the Piceance basin without depositing a significant layer of ash. It is impossible to estimate the contribution of this layer to the anomalously high coal ranks in the southern Piceance basin.

Erosion during the late Eocene to early Oligocene may have brought relatively high rank coals closer to the surface around the margins of the basin where the beveling was greatest (Johnson and Nuccio, 1986). Coal ranks along the steeply dipping eastern margin of the basin are much too high to have formed at their present shallow position in the basin and must have been brought up from deeper in the basin by the rising White River uplift during the late Eocene (fig. 17). In the southern part of the basin, late Eocene to early Oligocene uplift and beveling also occurred (fig. 16); the amount of late Eocene to early Oligocene beveling toward the southern margin of the basin is much less than the 5,500 ft rise in elevation indicated by the coal ranks. In addition, any post-early Oligocene coal metamorphism would have tended to flatten contacts between coal-rank zones. Thus, at best, beveling can explain only part of this rise.

\section{POTENTIAL FOR FUTURE MESAVERDE GAS PRODUCTION}

The potential for future Mesaverde gas production in the Piceance basin depends mostly on the development of improved well-completion and well-stimulation methods. Thus far, advances in well-completion techniques have been relatively modest and, except for the Corcoran and Cozzette interval, have not made the Mesaverde tight-gas reservoirs an attractive resource. Limited reservoir size and as yet unpredictable encounters with water-producing sandstones, particularly in areas peripheral to the main gas-saturated pocket, are major drawbacks to development. Attempts to generate, by using hydraulic fracturing techniques, large fracture systems that intersect several sandstone reservoirs have not been very successful. Until better completion techniques are developed, the most promising targets will remain the large, blanketlike reservoirs in the marine regressive cycles. Only the Corcoran and the Cozzette regressive cycles in the southern part of the basin have been extensively developed. Individual fields are beginning to coalesce, and Corcoran and Cozzette production probably will eventually be established throughout the southern part of the basin north of the stratigraphic pinchout of the two regressive cycles. Other regressive cycles such as the Rollins-Trout Creek, the upper and lower parts of the Sego, the middle and upper sandstones of Collins (1976), and the Castlegate are virtually untested. Considering the success of the Corcoran and Cozzette, the lack of interest in these other promising intervals is somewhat perplexing. Drilling of these regressive cycles should be most successful within $30-40 \mathrm{mi}$ of the marine pinchout of each cycle (fig. 5), where blanketlike sandstone reservoirs are likely to be common.

Among the most intriguing prospects in the Mesaverde are coal zones such as the Cameo-Fairfield coal zone. Sandstone reservoirs in this interval, although capable of producing some gas, generally are lenticular and of limited size. Although several recent completion attempts in the coals have shown much promise, problems have arisen in attempting to use conventional completion techniques on these unconventional reservoirs (Gas Research Institute, 1984).

Production will be enhanced wherever welldeveloped natural fracture systems are present. Structurally induced fracture systems along the crests of many of the anticlines in the basin are responsible for the better than average Mesaverde production in these areas, and structurally induced fracture systems should also exist along synclinal axes in the basin as well. These synclines are almost completely untested; the huge synclines west of the Grand Hogback and south of the White River dome (fig. 3) should be good exploration targets. The potential of these deep synclinal areas is also enhanced by the probable presence of very high formation pressures that would tend to keep natural fractures propped open. High formation pressures are probably responsible for the open nature of many of the fractures in the MWX core.

\section{DISCUSSION}

The Mesaverde low-permeability gas accumulation in the Piceance basin probably formed by a combination of intense regional diagenesis, which resulted in early permeability loss, followed by deep burial beneath lower Cenozoic sediments, which resulted in thermal gas generation by both the coaly intervals in the Mesaverde and the organic-rich intervals in the underlying Mancos Shale. The early permeability loss is required to trap gas in the deep central area of the basin where it was being generated. Even though rock-matrix permeability was low, considerable gas appears to have migrated into shallower thermally immature areas of the basin such as the White River dome. This migration may have been aided by extensive natural fracture systems. Because of 
these fracture systems, as well as some rock-matrix permeability, the gas accumulation is most likely a dynamic system and gas must be continuously be replaced or the size of the gas accumulation will diminish.

Three general zones in the Mesaverde gas accumulation can be defined: a zone of surface water invasion that extends inward a few miles from presentday outcrops toward the center of the basin, a gasand-water-bearing zone that extends perhaps $10-20 \mathrm{mi}$ inward from the water-bearing zone, and a central, predominantly gas bearing zone. This three-fold subdivision is similar to those of low-permeability gas accumulations in other Laramide basins. The scarcity of Mesaverde completions in many areas of the basin hinders an accurate definition of these three zones. In areas where adequate control is available, factors such as present-day formation temperature, thermal maturity, organic matter content, lithology, fracture density, and variations in the amount of overburden removed during the last $10 \mathrm{~m} . y$. all seem to influence the lateral and vertical extent of these three zones. The scarcity of Mesaverde completions makes it difficult to sort out the relative importance of these factors at this time.

Reconstruction of the geologic history of both the Piceance basin and the surrounding uplifts has greatly improved our knowledge of the conditions under which the gas accumulation formed. Deep weathering during the period of regional uplift and erosion that occurred before the overlying lower Cenozoic section was deposited is partly responsible for the intense regional diagenesis that affected the Mesaverde shortly after deposition. Diagenesis probably was also aided by the expulsion of highly reactive fresh water from coal seams. During the Paleocene, surface weathering of Mesaverde rocks ceased throughout most of the basin when the basin subsided and the Mesaverde was buried beneath Paleocene sediments. Throughout the Paleocene and Eocene, the Mesaverde continued to be exposed along the margins of the basin, adjacent to rising Laramide uplifts, and this ring of outcrops, as high as several thousand feet above the basin floor, may have produced artesian systems in the Mesaverde. Shortly after the end of the Laramide orogeny, the potential for artesian systems was mostly destroyed when the ring of Mesaverde outcrops was reduced to about the same elevation as the adjacent basin. The ring of Mesaverde outcrops persists to the present day and is still an area in which fluid movement into and out of the Mesaverde can occur. The Mesaverde, therefore, has had communication with the surface from early in the Laramide orogeny to the present day.

During the early Eocene, methane generation in the Mesaverde increased significantly in the deepest part of the basin when temperatures rose to higher than $250^{\circ} \mathrm{F}$ as a result of deep burial. Prior to the onset of gas generation, regional diagenesis must have reduced Mesaverde permeabilities in order for much gas to be trapped in the basin center. As the gas accumulation expanded, it probably pushed the overpressured artesiansupported formation water outward. As the basin continued to subside, the area of significant methane generation expanded, and, by the end of the Laramide orogeny, gas was being generated in at least the lower part of the Mesaverde throughout a large area of the central part of the basin. The area of generation possibly shrank somewhat during the final stages of the orogeny, when as much as several thousand feet of sediments was eroded from the margins of the basin, but methane generation continued throughout much of the central part of the basin where erosion was minimal.

Middle and late Cenozoic magmatism affected the southern part of the Piceance basin, and heat from these events probably was the primary cause of the higher than expected coal ranks in this area. Heating occurred both on a local scale, causing metamorphism around individual intrusions, and on a regional scale, raising the coal ranks throughout the entire region. Because of these heating events, it is difficult to reconstruct the thermal history of the area by using coal ranks. Coal-rank metamorphism models indicate that time and temperature are interchangeable, and hence a short but intense pulse of heat generates the same increase in coal rank as a prolonged but less intense heat pulse. In either case, these heat pulses would have caused the rate of gas generation to increase temporarily in this area of the basin.

During the past 10 m.y., the removal of as much as $5,000 \mathrm{ft}$ of overburden by downcutting of the Colorado River canyon system has radically altered reservoir conditions in the Mesaverde gas accumulation throughout the basin, but the effects of this downcutting have not yet been adequately studied. Porosity and permeability probably increased in proportion to the amount of downcutting as a result of an expansion of the pores and pore throats (Law and Dickinson, 1985). If so, then Mesaverde porosities and permeabilities will be significantly greater under the canyon bottoms than under the adjacent mesas. The rate of present-day methane generation in the Mesaverde under the canyon bottoms should also be much less than under the adjacent mesas. Some communication in the Mesaverde between the mesas and the canyon bottoms may occur as a result of fracturing. Unfortunately, it is impossible to compare methane generation in the mesas and the canyon floors because very little Mesaverde drilling has been done on the mesas. 


\section{REFERENCES CITED}

Balsley, J.K., 1982, Cretaceous wave-dominated delta system, Book Cliffs, east-central Utah: American Association of Petroleum Geologists Guidebook, 219 p.

Berry, F.A.F., 1959, Hydrodynamics and geochemistry of the Jurassic and Cretaceous systems in the San Juan basin, northwestern New Mexico and southwestern Colorado: Palo Alto, Calif., Stanford University, Ph. D. dissertation, $192 \mathrm{p}$.

Bostick, N.H., and Freeman, V.L., 1984, Tests of vitrinite reflectance and paleotemperature models at the Multiwell Experiment site, Piceance Creek basin, Colorado, in Spencer, C.W., and Keighin, C.W., eds., Geological studies in support of the U.S. Department of Energy Multiwell Experiment, Garfield County, Colorado: U.S. Geological Survey Open-File Report 84-757, p. $110-120$

Branagan, P., Cotner, G., and Lee, S.J., 1984, Interference testing of the naturally fractured Cozzette Sandstone; a case study at the DOE MWX site: Society of Petroleum Engineers/U.S. Department of Energy Symposium on Unconventional Gas Recovery, Pittsburgh, Pa., 1984, Proceedings 12869, p. 359-363.

Cashion, W.B., 1973, Geologic and structure map of the Grand Junction quadrangle, Colorado and Utah: U.S Geological Survey Miscellaneous Geologic Investigations Map I-736, scale 1:250,000.

Cashion, W.B., and Roehler, H.W., 1975, Stratigraphic section of part of the Green River Formation and underlying units exposed in Tommys Draw, western Piceance Creek basin, Colorado: U.S. Geological Survey Open-File Report 75-422, 16 p.

Chancellor, R.E., 1977, Mesaverde hydraulic fracture stimulation, northern Piceance Creek basin; progress report: Energy Research and Development Administration Symposium on Enhanced Oil and Gas Recovery and Drilling Methods, 3rd, Tulsa, Okla., 1977.

Chancellor, R.E., and Johnson, R.C., 1986, Geologic and engineering implications of production history from five wells in central Piceance Creek basin, northwest Colorado: Society of Petroleum Engineers Symposium on Unconventional Gas Technology, Louisville, Ky., 1986, Proceedings 15237, p. 351-364.

Chandler and Associates, Incorporated, 1980, Exhibits for proposed tight gas formation, Rollins-Cozette-Corcoran Sandstone, North Plateau Creek, Mesa County, Colorado: Colorado Oil and Gas Conservation Commission Hearing, Cause Number NG-7.

Clark, J.A., 1983, The prediction of hydraulic fracture azimuth through geological, core and analytical studies: Society of Petroleum Engineers/U.S. Department of Energy Symposium on Low Permeability Gas Reservoirs, Denver, Colo., 1983, Proceedings 11616, p. 107-114.

Clark, R.R., 1928, Economic geology of the Castlegate, Wellington, and Sunnyside quadrangles, Carbon County, Utah: U.S. Geological Survey Bulletin 793, 165 p.

Collins, B.A., 1976, Coal deposits of the Carbondale, Grand Hogback, and southern Danforth Hills coal fields, eastern Piceance basin, Colorado: Colorado School of Mines Quarterly, v. 71, no. 1, 138 p.

Colorado Oil and Gas Conservation Commission, 1985, Oil and gas statistics: Denver, Colorado, Colorado Oil and Gas Conservation Commission, $500 \mathrm{p}$.

Cullins, H.L., 1968, Geologic map of the Banty Point quadrangle, Rio Blanco County, Colorado: U.S. Geological Survey Geologic Quadrangle Map GQ-703, scale $1: 24,000$.

1969, Geologic map of the Mellen Hill quadrangle, Rio Blanco and Moffat Counties, Colorado: U.S. Geological Survey Geologic Quadrangle Map GQ-835, scale 1:24,000.

Donnell, J.R., 1962, Geology and coal resources of the Carbondale area, Garfield, Pitkin, and Gunnison Counties, Colorado: U.S. Geological Survey Open-File Report 62-38, 2 sheets.

Dula, W.F., Jr., 1981, Correlation between deformation lamellae, microfractures, macrofractures, and in situ stress measurements, White River uplift, Colorado: Geological Society of America Bulletin, v. 92, no. 1, p. 37-46.

Dyni, J.R., 1968, Geologic map of the Elk Springs quadrangle, Moffat County, Colorado: U.S. Geological Survey Geologic Quadrangle Map GQ-702, scale 1:62,500.

Eddy, G.E., Rightmire, C.T., and Byrer, C.W., 1982, Relationship of methane content of coal rank and depth; theoretical vs. observed: Society of Petroleum Engineers/U.S. Department of Energy Symposium on Unconventional Gas Recovery, Pittsburgh, Pa., 1982, Proceedings, p. 117-122.

Emmons, S.F., Cross, W., and Eldridge, G.H., 1894, Anthracite-Crested Butte, Colorado, folio 9 of Geologic atlas of the United States: U.S. Geological Survey, 11 p., 8 sheets.

Epis, R.C., and Chapin, C.E., 1975, Geomorphic and tectonic implications of the post-Laramide, late Eocene erosion surface in the southern Rocky Mountains, in Curtis, B.F., ed., Cenozoic history of the southern Rocky Mountains: Geological Society of America Memoir 144, p. 45-74.

Erdmann, C.E., 1934, The Book Cliffs coal field in Garfield and Mesa Counties, Colorado: U.S. Geological Survey Bulletin 851, 150 p.

Fenneman, N.M., and Gale, H.S., 1906, The Yampa coal field, Routt County, Colorado: U.S. Geological Survey Bulletin 297, 96 p.

Fisher, D.J., 1936, The Book Cliffs coal field in Emery and Grand Counties, Utah: U.S. Geological Survey Bulletin 852, 104 p.

Fisher, D.J., Erdmann, C.E., and Reeside, J.B., Jr., 1960, Cretaceous and Tertiary formations of the Book Cliffs, Carbon, Emery, and Grand Counties, Utah, and Garfield and Mesa Counties, Colorado: U.S. Geological Survey Professional Paper 332, 80 p.

Forrester, J.B., 1918, A short comment on bulletin 371 of the U.S. Geological Survey: Transactions of the Utah Academy of Sciences, v. 1, p. 24-31.

Fouch, T.D., Lawton, T.F., Nichols, D.J., Cashion, W.B., and Cobban, W.A., 1983, Patterns and timing of synorogenic sedimentation in Upper Cretacous rocks of central and northeast Utah, in Reynolds, M. W., and Dolly, E. D., eds., Mesozoic paleogeography of the west-central 
United States: Society of Economic Paleontologists and Mineralogists Rocky Mountain Paleogeography Symposium, 2nd, Denver, Colo., p. 305-336.

Freeman, V.L., 1979, Preliminary report on rank of deep coals in part of the southern Piceance Creek basin, Colorado: U.S. Geological Survey Open-File Report 79-725, 11 p.

Gale, H.S., 1910, Coal fields of northwestern Colorado and northeastern Utah: U.S. Geological Survey Bulletin 415, $265 \mathrm{p}$.

Gas Research Institute, 1984, Quarterly review of methane from coal seams technology: Chicago, Gas Research Institute, v. 2, no. 2, 27 p.

Giegengack, R.F., Jr., 1962, Recent volcanism near Dotsero, Colorado: Boulder, Colo., University of Colorado, M.S. thesis, $44 \mathrm{p}$.

Gies, R.M., 1982, Origin, migration and entrapment of natural gas in Alberta deep basin, part 2 [abs.]: American Association of Petroleum Geologists Bulletin, v. 66, p. 572.

1984, Case history for a major Alberta Deep Basin gas trap; the Cadomin Formation, in Masters, J.A., ed., Elmsworth; case study of a deep basin gas field: American Association of Petroleum Geologists Memoir 38, p. 115-140.

Gill, J.R., and Cobban, W.A., 1969, Paleogeographic maps, Western Interior: U.S. Geological Survey Open-File Report, 6 sheets.

Gill, J.R., and Hail, W.J., Jr., 1975, Stratigraphic sections across Upper Cretaceous Mancos Shale-Mesaverde Group boundary, eastern Utah and western Colorado: U.S. Geological Survey Oil and Gas Investigation Chart OC-68.

Granica, M.P., and Johnson, R.C., 1980, Structure contour and isochore map of the nonmarine part of the Mesaverde Group, Piceance Creek basin, Colorado: U.S. Geological Survey Miscellaneous Field Studies Map MF-1189, scale $1: 250,000$

Gries, R., 1983, Oil and gas prospecting beneath Precambrian of Foreland thrust plates in Rocky Mountains: American Association of Petroleum Geologists Bulletin, v. 67, no. 1, p. 1-28.

Grout, M.A., and Verbeek, E.R., 1983, Field studies of joints; insufficiencies and solutions, with examples from the Piceance Creek basin, Colo., in Proceedings of the 16th oil shale symposium: Golden, Colo., Colorado School of Mines Press, p. 68-80.

Gunter, C.E., 1962, Oil and gas potential of Upper Cretaceous sediments, southern Piceance Creek Basin, in Exploration for oil and gas in northwestern Colorado: Rocky Mountain Association of Geologists, p. 114-118.

Hail, W.J., Jr., 1973, Geologic map of the Smizer Gulch quadrangle, Rio Blanco and Moffat Counties, Colorado: U.S. Geological Survey Geologic Quadrangle Map GQ-1131, scale 1:24.000.

1974, Geologic map of the Rough Gulch quadrangle, Rio Blanco and Moffat Counties, Colorado: U.S. Geological Survey Geologic Quadrangle Map GQ-1195, scale $1: 24,000$.
Hancock, E.T., 1925, Geology and coal resources of the Axial and Monument Butte quadrangles, Moffat County, Colorado: U.S. Geological Survey Bulletin 757, 134 p.

Hancock, E.T., and Eby, J.B., 1930, Geology and coal resources of the Meeker quadrangle, Moffat and Rio Blanco Counties, Colorado: U.S. Geological Survey Bulletin 812, p. 191-242.

Hansley, P.L., 1981, Mineralogy, diagenesis, and provenance of Upper Cretaceous sandstones from the Ralston Production Company Federal no. 31 well, Piceance Creek basin, northwestern Colorado: U.S. Geological Survey Open-File Report 81-1295, 23 p.

Hansley, P.L., and Johnson, R.C., 1980, Mineralogy and diagenesis of low-permeability sandstones of Late Cretaceous age, Piceance Creek basin, northwestern Colorado: Mountain Geologist, v. 17, no. 4, p. 88-106.

Heinze, D.M., 1983, Mineralogy and petrology aspects of Mesaverde Formation at Rifle Gap, Colorado, specific to the sedimentary and gas-bearing intervals in the subsurface: Albuquerque, N. Mex., Sandia National Laboratories Report SAND 83-0287, 38 p.

Hills, R.C., 1891, Orographic and structural features of Rocky Mountain geology: Colorado Scientific Society Proceedings, v. 3, p. 362-468.

Hunt, C.B., 1969, Geologic history of the Colorado River: U.S. Geological Survey Professional Paper 669, p. 59-130.

Izett, G.A., Honey, J.G., and Brownfield, M.E., 1985, Geologic map of the Citadel Plateau quadrangle, Moffat County, Colorado: U.S. Geological Survey Miscellaneous Investigations Series Map I-1532, scale 1:48,000.

Johnson, R.C., 1979a, Cross section $A-A^{\prime}$ of Upper Cretaceous and lower Tertiary rocks, northern Piceance Creek basin, Colorado: U.S. Geological Survey Miscellaneous Field Studies Map MF-1129-A, 2 sheets.

$1979 \mathrm{~b}$, Cross section $B-B^{\prime}$ of Upper Cretaceous and lower Tertiary rocks, northern Piceance Creek basin, Colorado: U.S. Geological Survey Miscellaneous Field Studies Map MF-1129-B, 2 sheets.

1979c, Cross section $C-C^{\prime}$ of Upper Cretaceous and lower Tertiary rocks, northern Piceance Creek basin, Colorado: U.S. Geological Survey Miscellaneous Field Studies Map MF-1129-C, 2 sheets.

1982, Measured section of the Late Cretaceous Mesaverde Group and lower part of the Lower Tertiary Wasatch Formation, Rifle Gap, Colorado: U.S. Geological Survey Open-File Report 82-590, 11 p.

1983, Structure contour map of the top of the Rollins Sandstone Member of the Mesaverde Formation and Trout Creek Sandstone Member of the Iles Formation, Piceance Creek basin, Colorado: U.S. Geological Survey Miscellaneous Field Studies Map MF-1667, scale $1: 253,440$.

1984, New names for units in the lower part of the Green River Formation, Piceance Creek basin, Colorado: U.S. Geological Survey Bulletin 1529-I, 20 p.

1985a, Early Cenozoic history of the Uinta and Piceance Creek basins, Utah and Colorado, with special reference to the development of Eocene Lake Uinta, in Flores, R.M., and Kaplin, S.S., eds., Cenozoic paleo- 
geography of the West-Central United States: Society of Economic Paleontologists and Mineralogists Rocky Mountain Paleogeography Symposium, 3rd, Denver, Colo., 1985, p. 247-276.

1985b, Preliminary geologic map of the Baxter Pass quadrangle, Garfield County, Colorado: U.S. Geological Survey Miscellaneous Field Studies Map MF-1813, scale $1: 24,000$.

1986, Structure contour map of the top of the Castlegate Sandstone, eastern part of the Uinta basin and the western part of the Piceance Creek basin, Utah and Colorado: U.S. Geological Survey Miscellaneous Field Studies Map MF-1826, scale 1:253,440.

Johnson, R.C., and Finn, T.M., 1985, Age of the Douglas Creek arch, Colorado and Utah [abs.]: American Association of Petroleum Geologists, v. 69, no. 3, p. 270.

1986, Cretaceous through Holocene history of the Douglas Creek arch, Colorado and Utah, in Stone, D.S., ed., New interpretations of northwest Colorado geology: Rocky Mountain Association of Geologists, p. 75-77.

Johnson, R.C., Granica, M.P., and Dessenberger, N.C., 1979a, Cross section $A-A^{\prime}$ of Upper Cretaceous and lower Tertiary rocks, southern Piceance Creek basin, Colorado: U.S. Geological Survey Miscellaneous Field Studies Map MF-1130-A, 2 sheets.

1979b, Cross section $B-B^{\prime}$ of Upper Cretaceous and lower Tertiary rocks, southern Piceance Creek basin, Colorado: U.S. Geological Survey Miscellaneous Field Studies Map MF-1130-B, 2 sheets.

1979c, Cross section $C-C^{\prime}$ of Upper Cretaceous and lower Tertiary rocks, southern Piceance Creek basin, Colorado: U.S. Geological Survey Miscellaneous Field Studies Map MF-1130-C, 2 sheets.

Johnson, R.C., and Keighin, C.W., 1981, Cretaceous and Tertiary history and resources of the Piceance Creek basin, western Colorado: New Mexico Geological Society Field Conference, 32nd, Western Slope, Colorado, 1981, Guidebook, p. 199-210.

Johnson, R.C., and May, Fred, 1978, Preliminary stratigraphic studies of the upper part of the Mesaverde Group, the Wasatch Formation, and the lower part of the Green River Formation, DeBeque area, Colorado, including environments of deposition and investigation of palynomorph assemblages: U.S. Geological Survey Miscellaneous Field Studies Map MF-1050, 2 sheets.

1980, A study of the Cretaceous-Tertiary unconformity in the Piceance Creek basin, Colorado; the Ohio Creek Formation (Upper Cretaceous) redefined as a member of the underlying Hunter Canyon or Mesaverde Formation: U.S. Geological Survey Bulletin 1482-B, $27 \mathrm{p}$.

Johnson, R.C., May, F., Hansley, P.L., Pitman, J.K., and Fouch, T.D., 1980, Petrography and palynology of a measured section of the Upper Cretaceous Mesaverde Group in Hunter Canyon, western Colorado: U.S. Geological Survey Oil and Gas Investigations Chart OC-91.

Johnson, R.C., and Nuccio, V.F., 1986, Structural and thermal history of the Piceance Creek basin, western Colorado, in relation to hydrocarbon occurrence in the Mesaverde
Group, in Spencer, C.W., and Mast, R.F., eds., Geology of tight gas reservoirs: American Association of Petroleum Geologists Studies in Geology 24, p. 165-206.

Juntgen, H., and Karweil, J., 1966, Gasbildung und gasspeicherung in steinkohlenflozen, I und II [Formation and storage of gas in bituminous coal seams]: Erdol und Kohle, Erdgas, Petrochemie, v. 19, p. 251-258, 339-344.

Konish, K., 1959, Upper Cretaceous surface stratigraphy, Axial basin and Williams Fork area, Moffat and Routt Counties, Colorado: Rocky Mountain Association of Geologists Field Conference Symposium, 11th, p. 67-73.

Larson, E.E., Ozima, M., and Bradley, W.C., 1975, Late Cenozoic basic volcanism in northwestern Colorado and its implications concerning tectonism and the origin of the Colorado River system, in Curtis, B.F., ed., Cenozoic history of the southern Rocky Mountains: Geological Society of America Memoir 144, p. 155-178.

Law, B.E., 1984, Relationships of source-rock, thermal maturity, and overpressuring to gas generation and occurrence in low-permeability Upper Cretaceous and lower Tertiary rocks, greater Green River basin, Wyoming, Colorado, and Utah, in Woodward, J., Meissner, F.F., and Clayton, J.L., eds., Hydrocarbon source rocks of the greater Rocky Mountain region: Rocky Mountain Association of Geologists Symposium, Denver, Colo,, 1984 , p. 469-490.

Law, B.E., and Dickinson, W.W., 1985, Conceptual model for the origin of abnormally pressured gas accumulations in low-permeability reservoirs: American Association of Petroleum Geologists, v. 69, no. 8, p. 1295-1304.

Law, B.E., and Smith, C.R., 1983, Subsurface temperature map showing depth to $180^{\circ} \mathrm{F}$ in the greater Green River basin of Wyoming, Colorado and Utah: U.S. Geological Survey Miscellaneous Field Investigations Map MF-1504, scale $1: 500,000$.

Law, B.E., and Spencer, C.W., 1981, Abnormally highpressured, low-permeability, Upper Cretaceous and Tertiary gas reservoirs, northern Green River basin, Wyoming [abs.]: American Association of Petroleum Geologists Bulletin, v. 65, no. 5, p. 948.

Law, B.E., Spencer, C.W., and Bostick, N.H., 1979, Preliminary results of organic maturation, temperature, and pressure studies in the Pacific Creek area, Sublette County, Wyoming: U.S. Department of Energy Symposium on Enhanced Oil and Gas Recovery and Improved Drilling Methods, 5th, Tulsa, Okla., 1979, p. K2/1-13.

1980, Evaluation of organic matter, subsurface temperature and pressure in low-permeability Upper Cretaceous and lower Tertiary sandstones in Pacific Creek area, Sublette and Sweetwater Counties, Wyoming: Mountain Geologist, v. 17, no. 2, p. 23-35.

Lee, W.T., 1912, Coal fields of Grand Mesa and the West Elk Mountains, Colorado: U.S. Geological Survey Bulletin $510,237 \mathrm{p}$.

Lorenz, J.C., 1982, Sedimentology of the Mesaverde Formation at Rifle Gap, Colorado, and implications for gas-bearing intervals in the subsurface: Albuquerque, N. Mex., Sandia National Laboratories Report SAND82-0604, 44 p. 
1984, Reservoir sedimentology of Mesaverde rocks at the MWX site, in Spencer, C.W., and Keighin, C.W., 1984, Geologic studies in support of the U.S. Department of Energy Multiwell Experiment, Garfield County, Colorado: U.S. Geological Survey Open-File Report 84-757, p. 21-32.

Lorenz, J.C., and Rutledge, A.K., 1985, Facies relationships and reservior potential of Ohio Creek interval across Piceance Creek basin, northwestern Colorado: Albuquerque, N. Mex., Sandia National Laboratories Report SAND84-2610, 52 p.

Mann, R.L., 1984, Multiwell experiment drilling review: Western Gas Sands Subprogram Review, Morgantown, W. Va., Technical Proceedings, DOE/METC/84-3, p. 155-164.

Marvin, R.F., Mehnert, H.H., and Mountjoy, W.M., 1966, Age of basalt cap on Grand Mesa, in Geological Survey research 1966: U.S. Geological Survey Professional Paper 550-A, p. A81.

Masters, J.A., 1979, Deep basin gas trap, western Canada: American Association of Petroleum Geologists Bulletin, v. 63 , no. 2 , p. $152-181$.

McPeek, L.A., 1981, Eastern Green River basin; a developing giant gas supply from deep, overpressured Upper Cretaceous sandstones: American Association of Petroleum Gcologists Bulletin, v. 65, no. 6, p. 1078-1098.

Meissner, F.F., 1978, Patterns of source-rock maturity in nonmarine source-rocks of some typical Western Interior basins, in Nonmarine Tertiary and Upper Cretaceous source rocks and the occurrence of oil and gas in West Central U.S.: Rocky Mountain Association of Geologists Continuing Education Lecture Series, p. 1-37.

1984, Cretaceous and Lower Tertiary coals as sources for gas accumulations in the Rocky Mountain area, in Woodward, J., Meissner, F.F., and Clayton, J.L., eds., Hydrocarbon source rocks of the greater Rocky Mountain region: Rocky Mountain Association of Geologists Symposium, Denver, Colo., 1984, p. 401-432.

Meissner, F.F., Woodward, J., and Clayton, J.L., 1984, Stratigraphic relationships and distribution of source rocks in the greater Rocky Mountain region, in Woodward, J., Meissner, F.F., and Clayton, J.L., eds., Hydrocarbon source rocks of the greater Rocky Mountain region: Rocky Mountain Association of Geologists Symposium, Denver, Colo., 1984, p. 1-34.

Murray, F.N., 1967, Jointing in sedimentary rocks along the Grand Hogback monocline, Colorado: Journal of Geology, v. 75 , no. 3 , p. $340-350$.

National Petroleum Council, 1980, Tight gas reservoirs, part I, in National Petroleum Council unconventional gas resources: Washington, D.C., National Petroleum Council, 222 p.

Noe, D.C., 1983, Storm-dominated shoreface deposits, Sego Sandstone (Campanian), northwestem Colorado [abs.]: American Association of Petroleum Geologists Bulletin, v. 67 , no. 3, p. 454.

Nuccio, V.F., and Johnson, R.C., 1981, Map showing drill stem test and perforation recoveries of the Upper Cretaceous
Mesaverde Group, Piceance Creek basin, Colorado: U.S. Geological Miscellaneous Field Studies Map MF-1359, scale 1:250,000.

1983, Preliminary thermal maturity map of the CameoFairfield or equivalent coal zone through the Piceance Creek basin, Colorado: U.S. Geological Survey Miscellaneous Field Studies Map MF-1575, scale $1: 253,440,2$ sheets.

Pitman, J.K., and Spencer, C.W., 1984, Petrology of selected sandstones in the MWX wells (northwest Colorado) and its relationship to borehole geophysical-log analysis and reservior quality, in Spencer, C.W., and Keighin, C.W., eds., Geologic studies in support of the U.S. Department of Energy Multiwell Experiment, Garfield County, Colorado: U.S. Geological Survey Open-File Report 84-757, p. 33-66.

Pitman, J.K., and Sprunt, E.S., 1984, Origin and occurrence of fracture-filling cements in the Upper Cretaceous Mesaverde Formation at MWX, Piceance Creek basin, Colorado, in Spencer, C.W., and Keighin, C.W., eds., Geologic studies in support of the U.S. Department of Energy Multiwell Experiment, Garfield County, Colorado: U.S. Geological Survey Open-File Report 84-757, p. 87-101.

Rice, D.D., 1983, Relation of natural gas composition to thermal maturity and source rock type in San Juan basin, northwestern New Mexico and southwestern Colorado: American Association of Petroleum Geologists Bulletin, v. 67, no. 3, p. 1199-1218.

Rio Blanco Natural Gas Company, 1980, High-cost natural gas produced from tight formations, geologic and engineering summary, Rio Blanco and Dry Gulch unit areas, Rio Blanco County, Colorado: Federal Energy Regulatory Commission, Docket No. RM79-76, 39 p.

Sattler, A.R., 1984, The Multiwell Experiment core program: Society of Petroleum Engineers/U.S. Department of Energy/Gas Research Institute Unconventional Gas Recovery Symposium, Dallas, Tex., 1984, Proceedings, p. 235-244.

Smith, R.S., and Whitney, J.W., 1979, Map of joint sets and airphoto lineaments of the Piceance Creek basin, northwestern Colorado: U.S. Geological Survey Miscellaneous Field Studies Map MF-1128, scale $1: 100,000,2$ sheets.

Spencer, C.W., 1983, Geologic aspects of tight gas reservoirs in the Rocky Mountain region: Society of Petroleum Engineers/U.S. Department of Energy Symposium on Low Permeability Gas Reservoirs, Denver, Colo., 1983, Proceedings, p. 399-408.

1984, Overview of U.S. Department of Energy Multiwell Experiment, Piceance Creek basin, Colorado, in Spencer, C.W., and Keighin, C.W., eds:, Geologic studies in support of U.S. Department of Energy Multiwell Experiment, Garfield County, Colorado: U.S. Geological Survey Open-File Report 84-757, p. 1-13.

Spencer, C.W., and Keighin, C.W., eds., 1984, Geologic studies in support of the U.S. Department of Energy Multiwell Experiment, Garfield County, Colorado: U.S. Geological Survey Open-File Report 84-757, 134 p. 
Spencer, C.W., and Law, B.E., 1981, Overpressured, lowpermeability gas reservoirs in Green River, Washakie, and Great Divide basins, southwestern Wyoming [abs.]: American Association of Petroleum Geologists Bulletin, v. 65 , no. 3, p. 569 .

Spieker, E.M., and Reeside, J.B., Jr., 1925, Cretaceous and Tertiary formations of the Wasatch Plateau, Utah: Geological Society of America Bulletin, v. 36, no. 3, p. 435-454

Stone, D.S., 1977, Tectonic history of the Uncompahgre uplift, in Veal, H.K., ed., Exploration frontiers of the central and southern Rockies: Rocky Mountain Association of Geologists Field Conference, 1977, Guidebook, p. 23-30.

Stright, D.H., Jr., and Gordon, J.I., 1983, Decline curve analysis in fractured low permeability gas wells in the Piceance Creek basin: Society of Petroleum Engineers/U.S. Department of Energy Symposium on Low Permeability Gas Reservoirs, Denver, Colo., 1983, Proceedings, p. 351-362.

Thomas, R.D., and Ward, D.C., 1972, Effect of overburden pressure and water saturation on gas permeability of tight sandstone cores: Journal of Petroleum Technology, February, p. 120-124.

Tichy, J.R., and Rettger, R.W., 1961, Divide Creek field: Rocky Mountain Association of Geologists Oil and Gas Field Volume, Colorado-Nebraska-1961, p.110-111.

Tweto, O., 1975, Laramide (late Cretaceous-early Tertiary) orogeny in the southern Rocky Mountains, in Curtis, B.F., ed., Cenozoic history of the southern Rocky Mountains: Geological Society of America Memoir 144, p. $1-44$.

Verbeek, E.R., and Grout, M.A., 1983, Fracture history of the northern Piceance Creek basin, northwestern Colorado, in Proceedings of the 16th oil shale symposium: Golden, Colo., Colorado School of Mines Press, p. 26-44. 1984a, Fracture studies in Cretaceous and Paleocene strata in and around the Piceance basin, Colorado; preliminary results and their bearing on a fracturecontrolled natural-gas reservoir at the MWX site: U.S. Geological Survey Open-File Report 84-156, 32 p.

$1984 \mathrm{~b}$, Prediction of subsurface fracture patterns from surface studies of joints; an example from the Piceance Creek basin, Colorado, in Spencer, C.W., and Keighin, C.W., eds., Geological studies in support of the U.S. Department of Energy Multiwell Experiment, Garfield County, Colorado: U.S. Geological Survey Open-File Report 84-757, p. 75-86.

Warner, D.L., 1964, Mancos-Mesaverde (Upper Cretaceous) intertonguing relations, southeast Piceance Basin, Colorado: American Association of Petroleum Geologists Bulletin, v. 48, no. 7, p. 1091-1107.

Welte, D.H., Schaefer, R.G., Radke, M., and Weiss, H.M., 1982 , Origin, migration, and entrapment of natural gas in Alberta Deep basin, part 1 [abs.]: American Association of Petroleum Geologists Bulletin, v. 66, no. 5, p. 642.

Young, R.G., 1955, Sedimentary facies and intertonguing in the Upper Cretaceous of the Book Cliffs, Utah-Colorado: Geological Society of America Bulletin, v. 55, p. 177-202.

1966, Stratigraphy of coal-bearing rocks of the Book Cliffs, Utah-Colorado, in Central Utah coals, a guidebook prepared for the Geological Society of America and associated societies: Utah Geological and Mineralogical Survey Bulletin, v. 80 , p. 7-21.

1982, Stratigraphy and petroleum geology of the Mesaverde Group, southeastern Piceance Creek basin, Colorado: Grand Junction Geological Society, Field Trip, Southeastern Piceance Basin, 1982, p. 45-54.

Zapp, A.D., and Cobban, W.A., 1960, Some Late Cretaceous strand lines in northwestern Colorado and northeastern Utah: U.S. Geological Survey Professional Paper 400-B, p. B246-B249. 



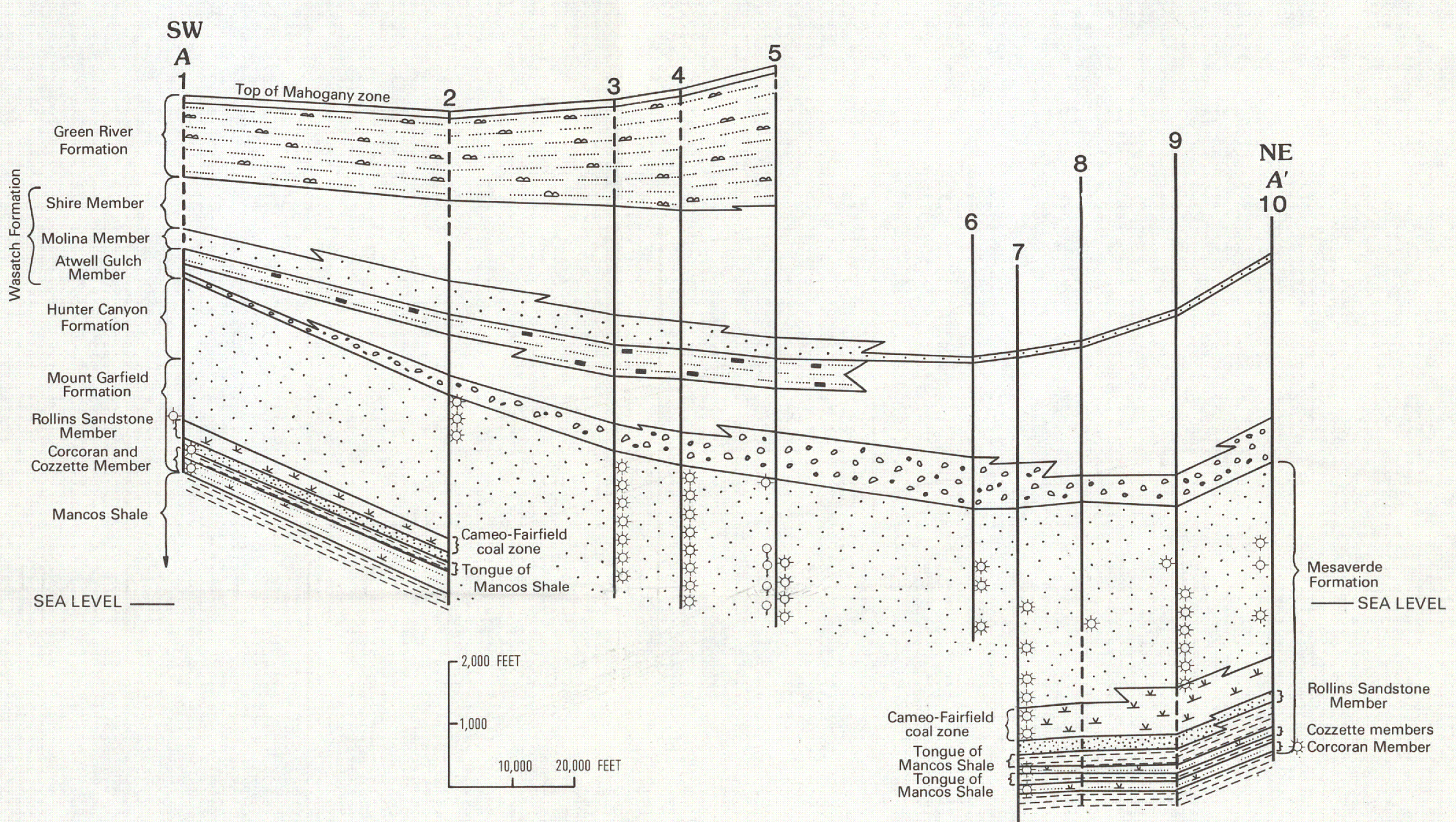

A. COLORADO RIVER VALLEY, SOUTHERN PICEANCE BASIN

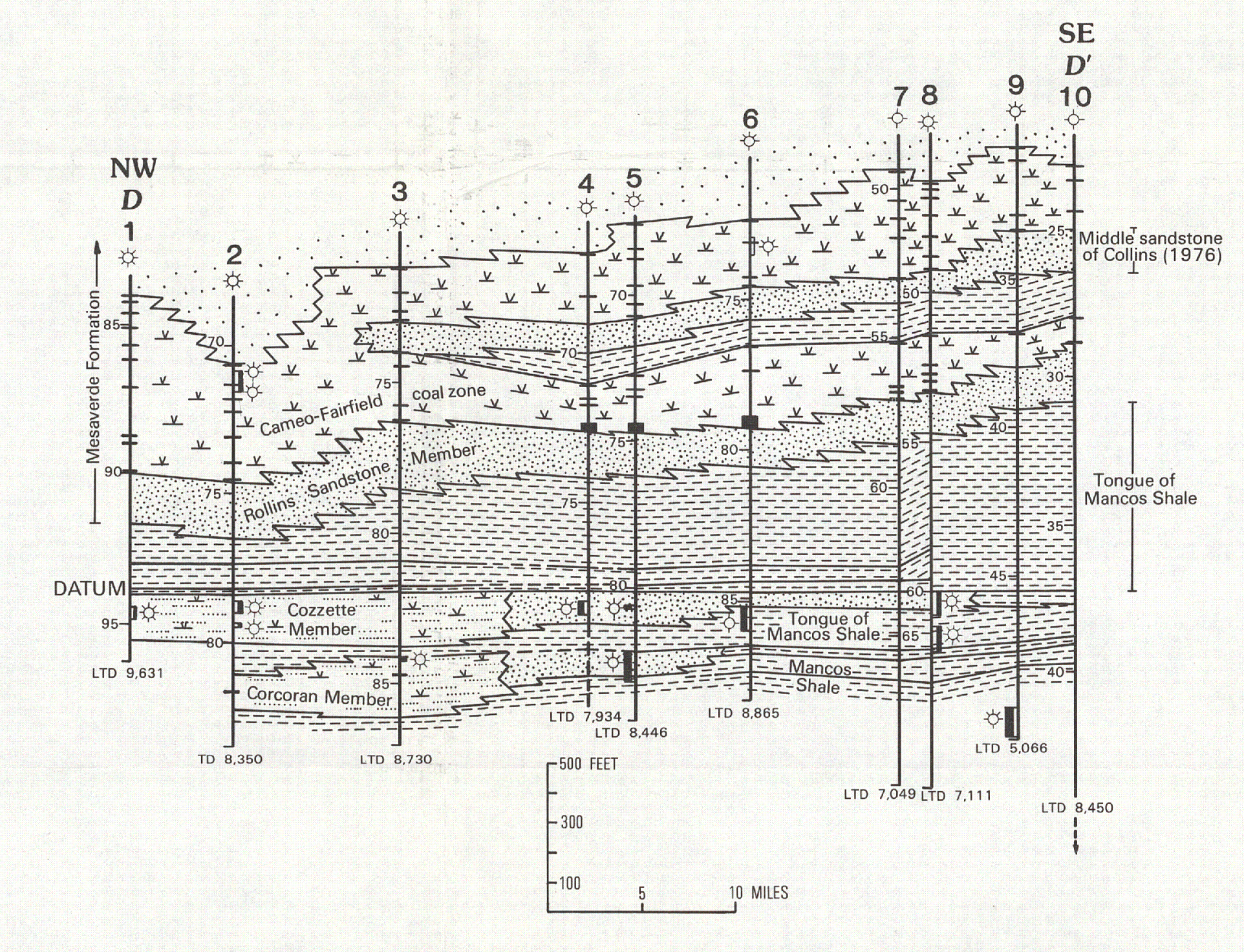

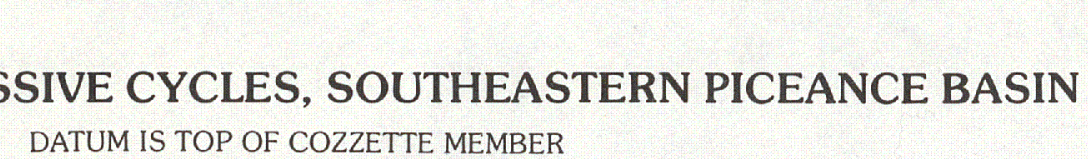

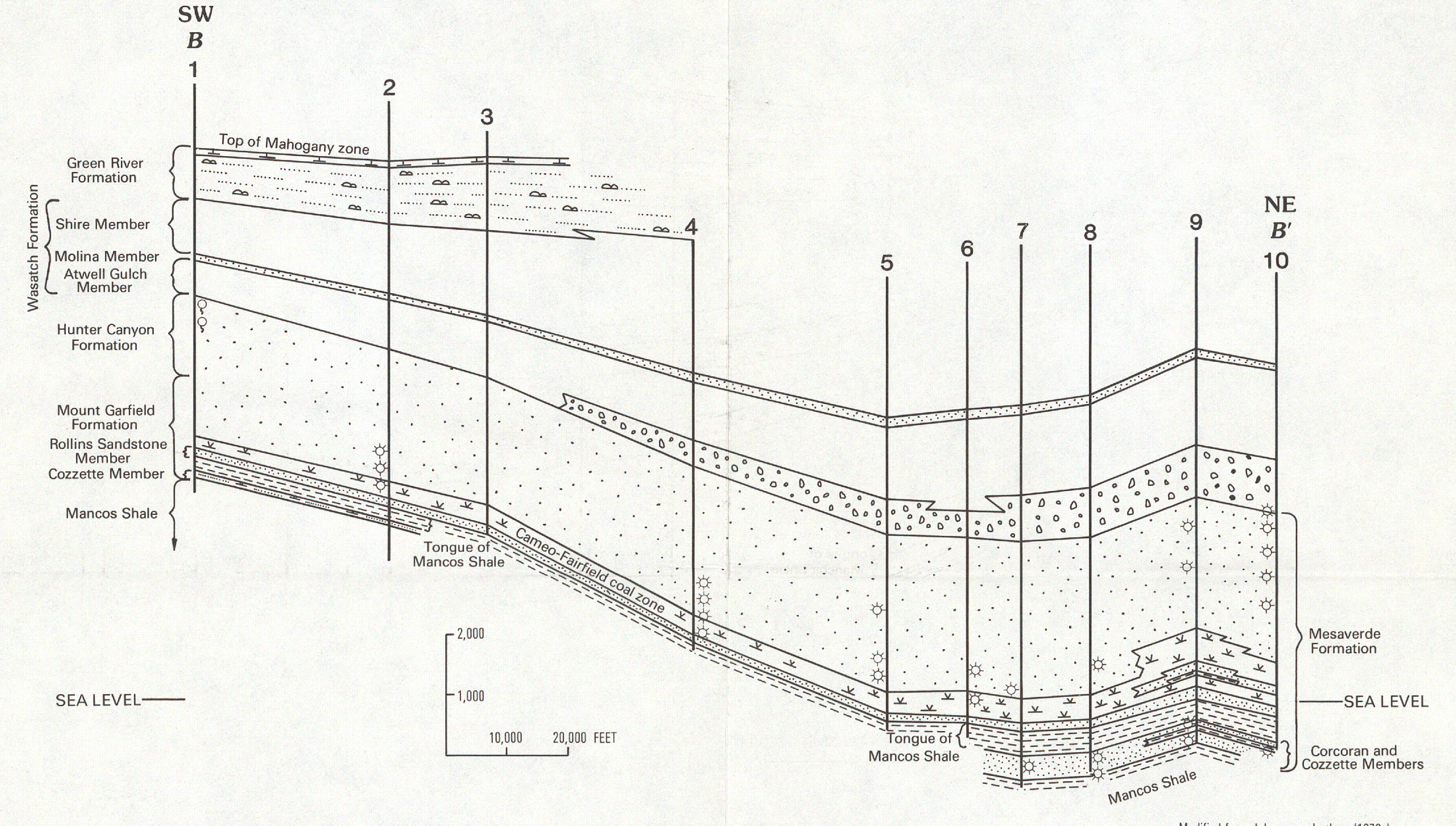

B. SOUTH OF THE COLORAD RIVER VALLEY, PICEANCE BASIN

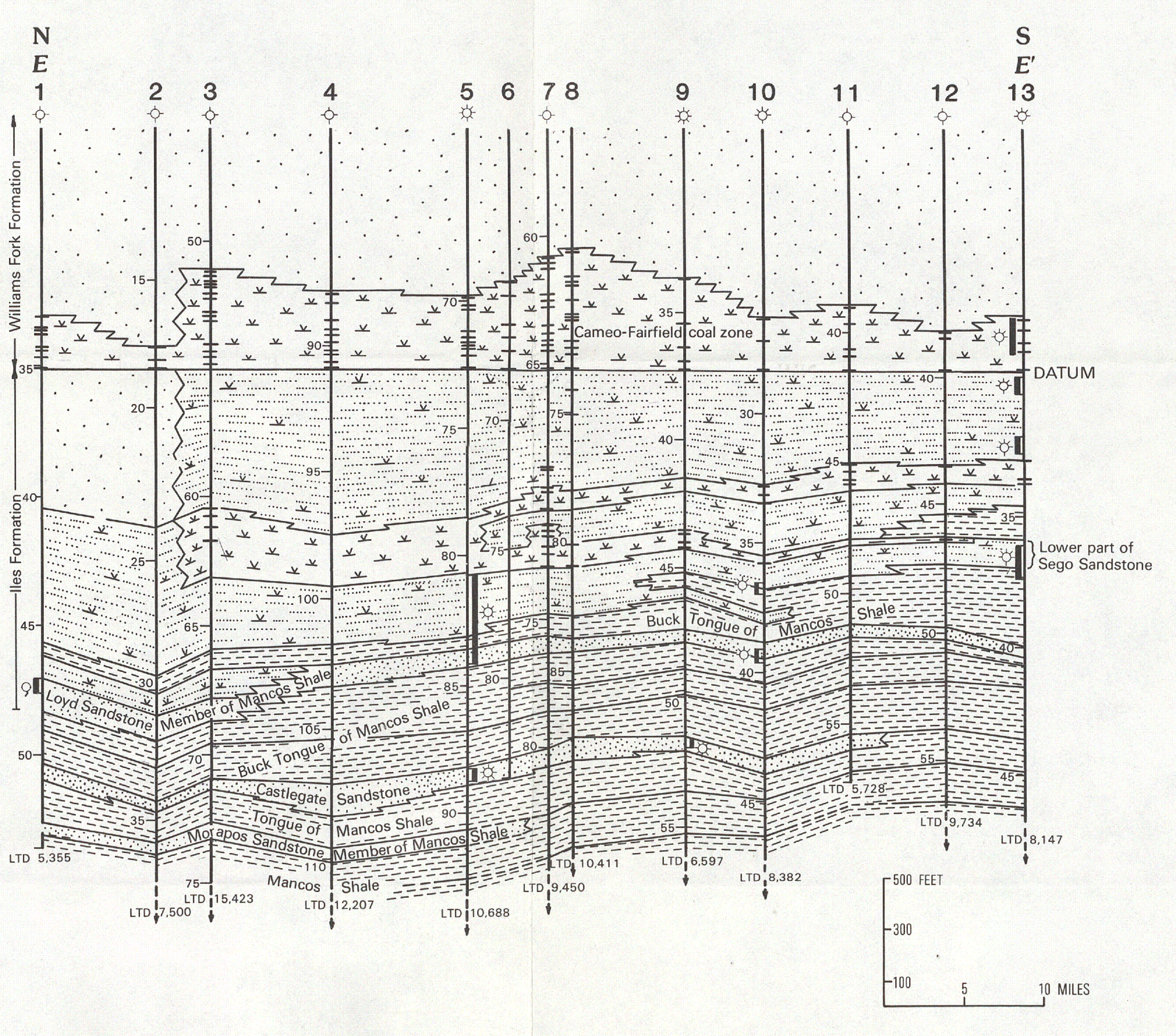

E. MESAVERDE REGRESSIVE CYCLES, NORTTWESTERN PICEANCE BASIN

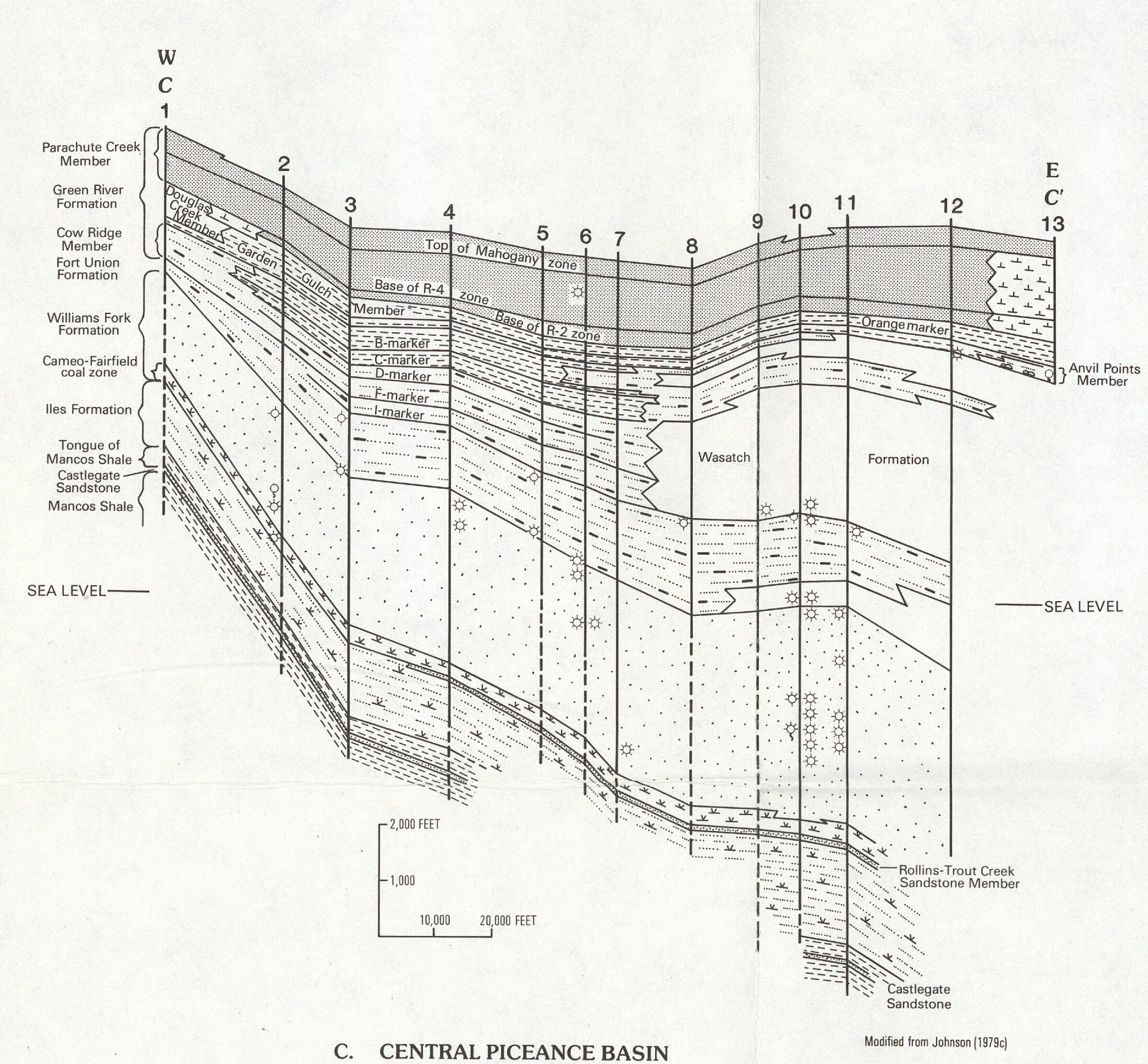

c. CENTRAL PICEANCE BASIN

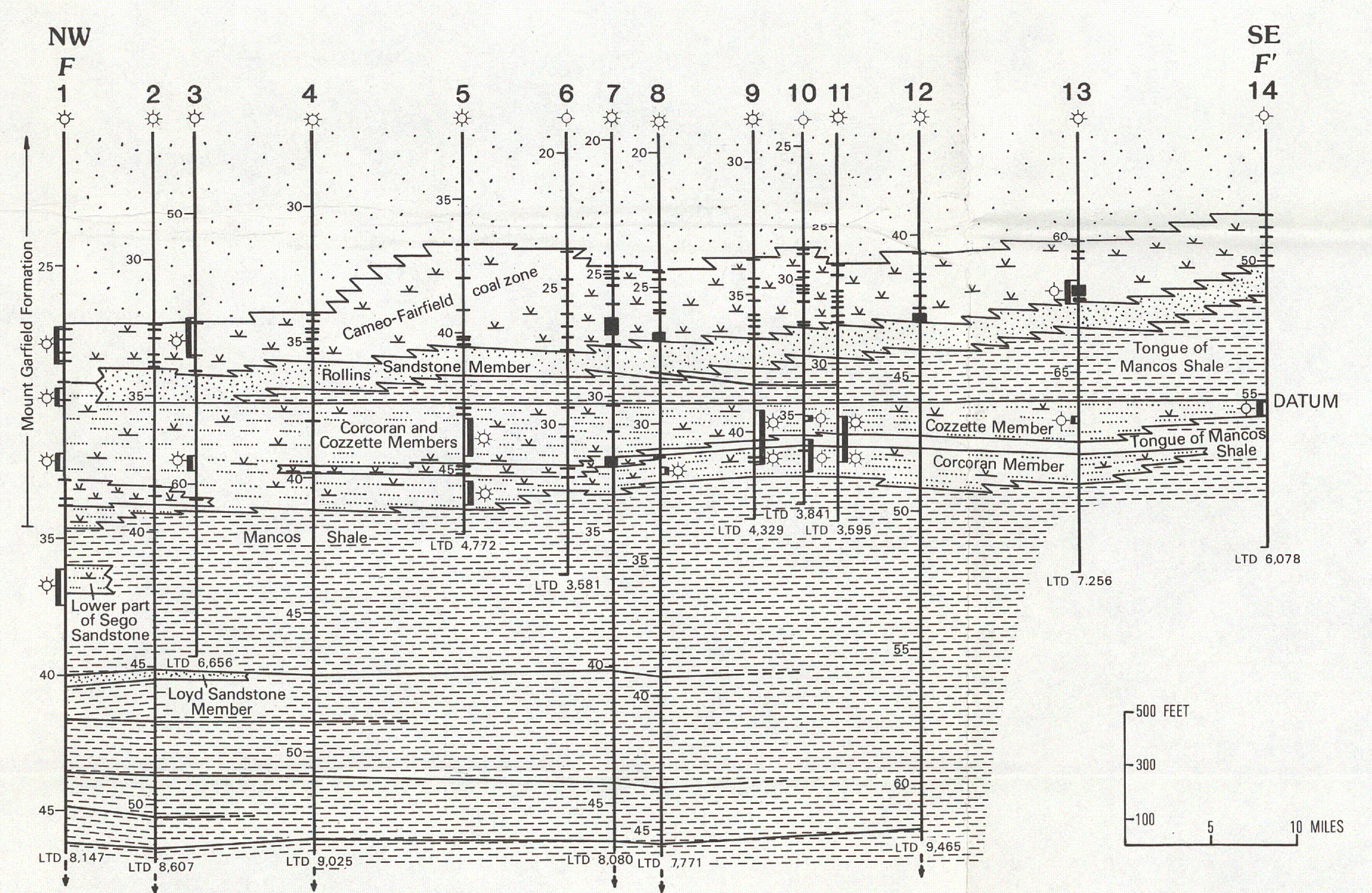

F. MESAVERDE REGRESSIVE CYCLESS SOUTHWESTERN PICEANCE BASIN

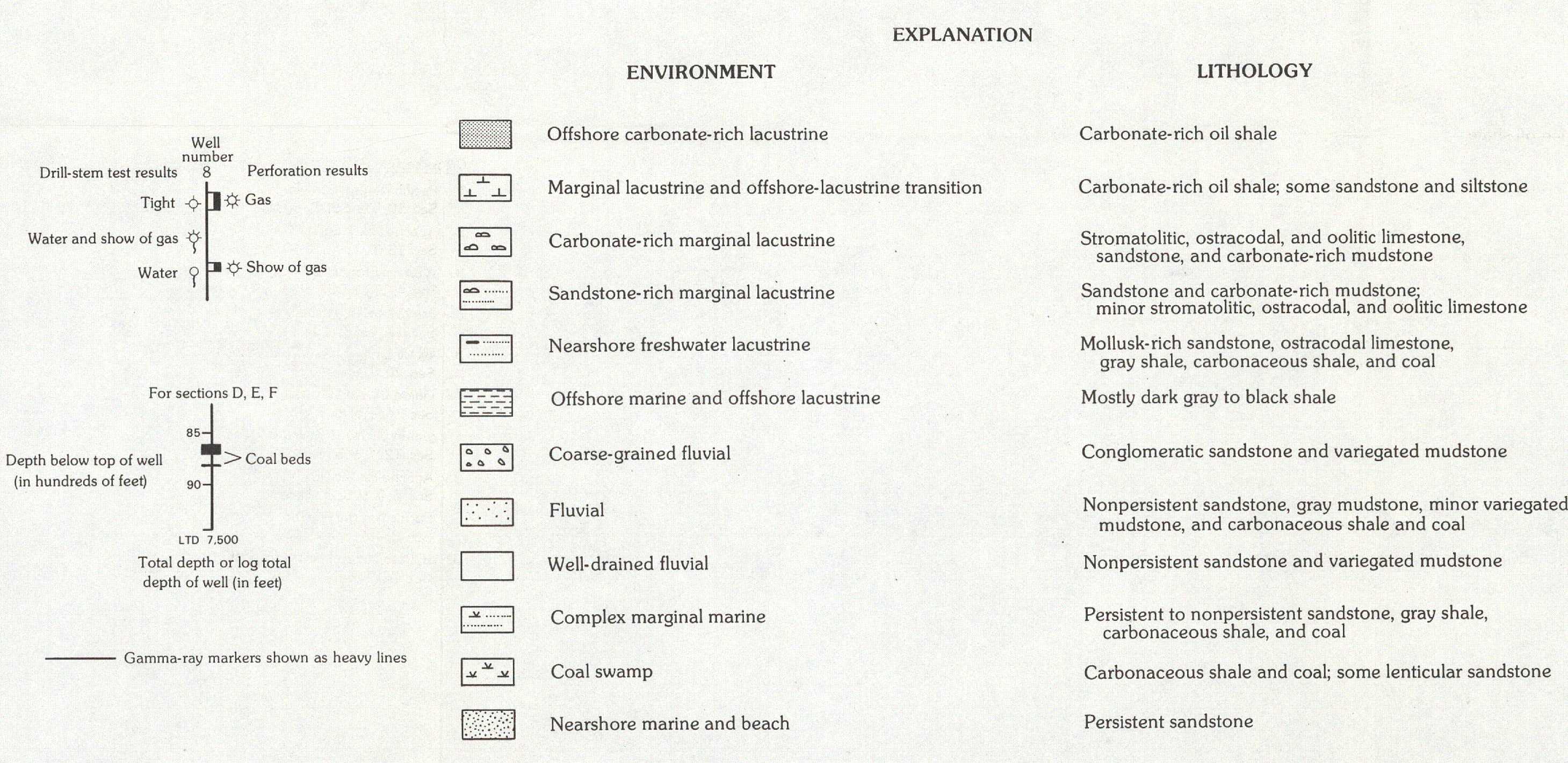

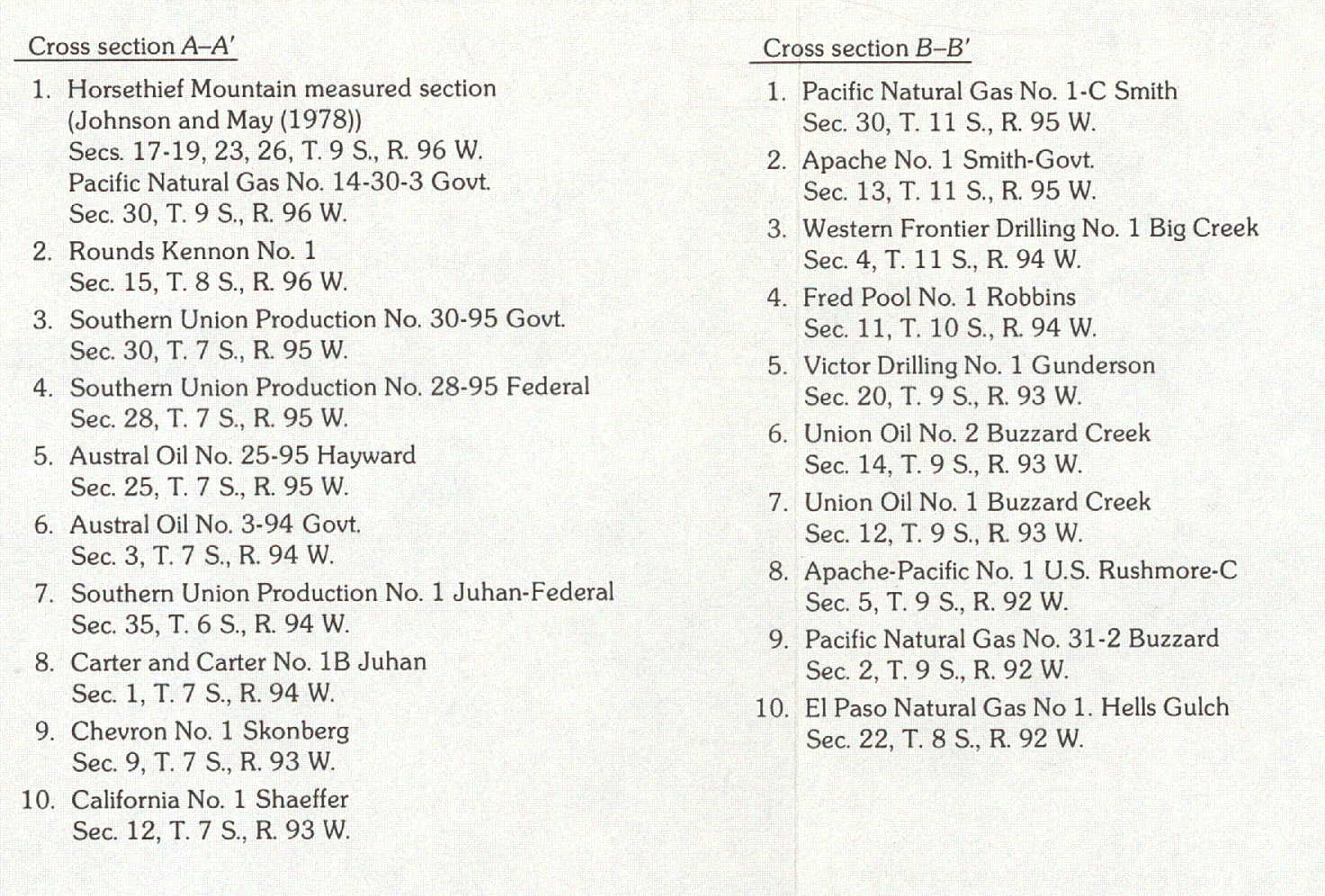

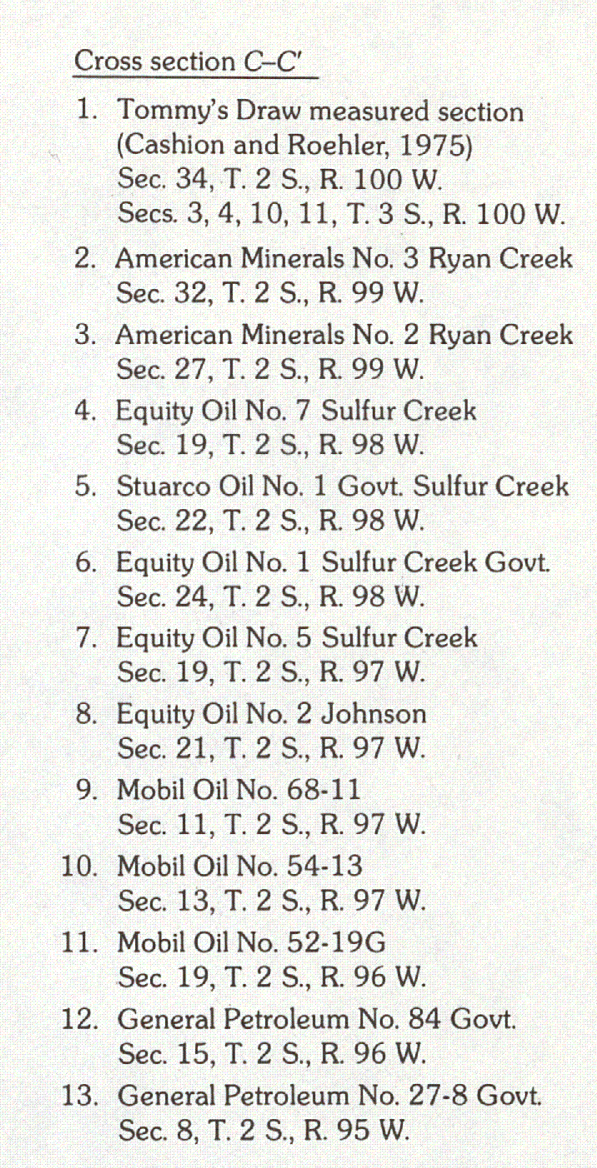

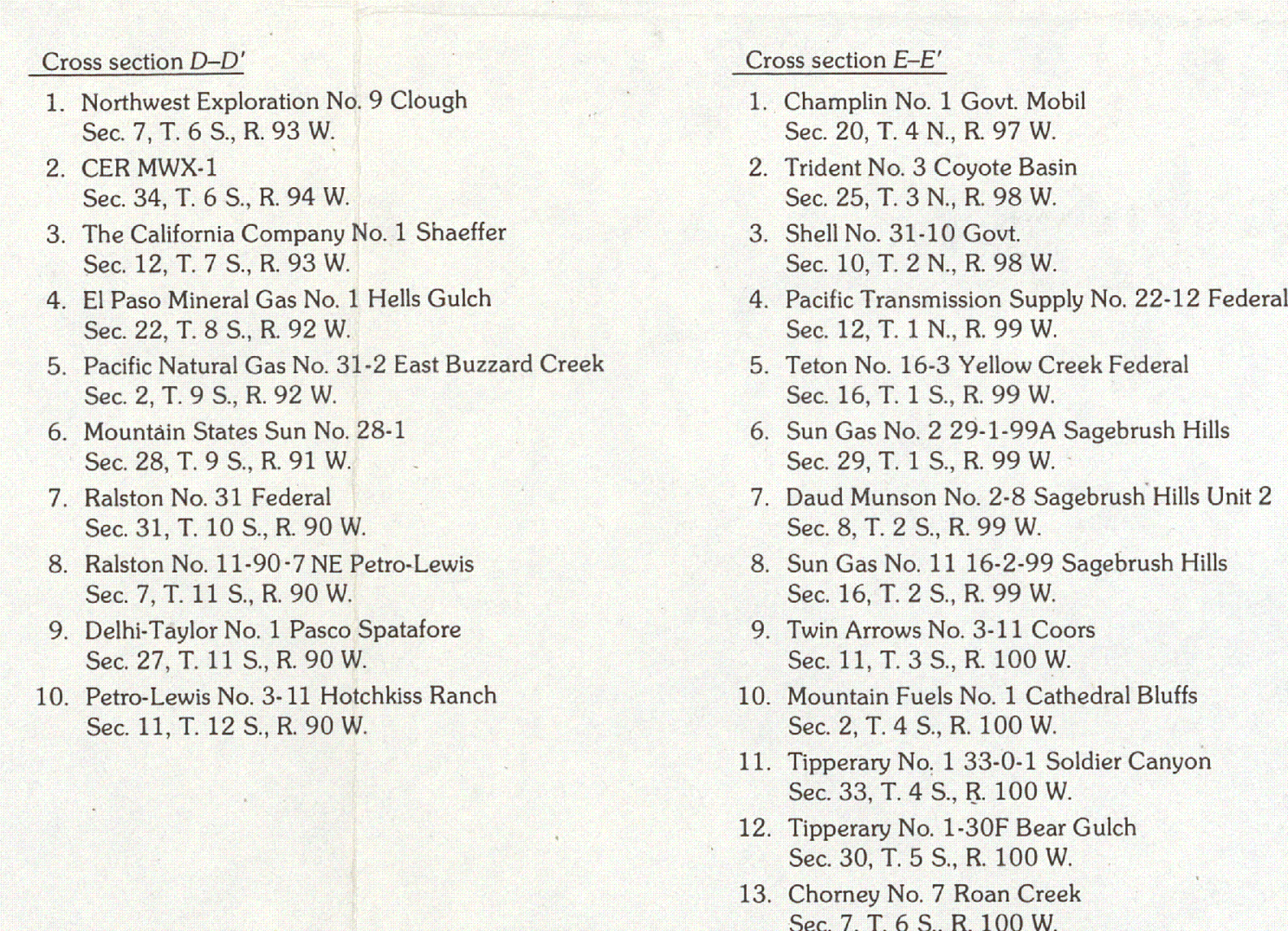

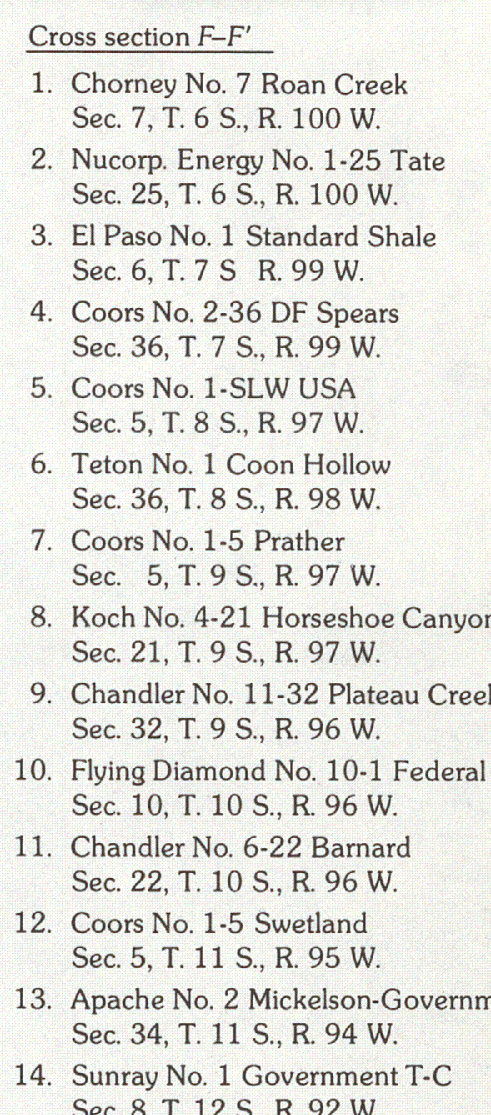

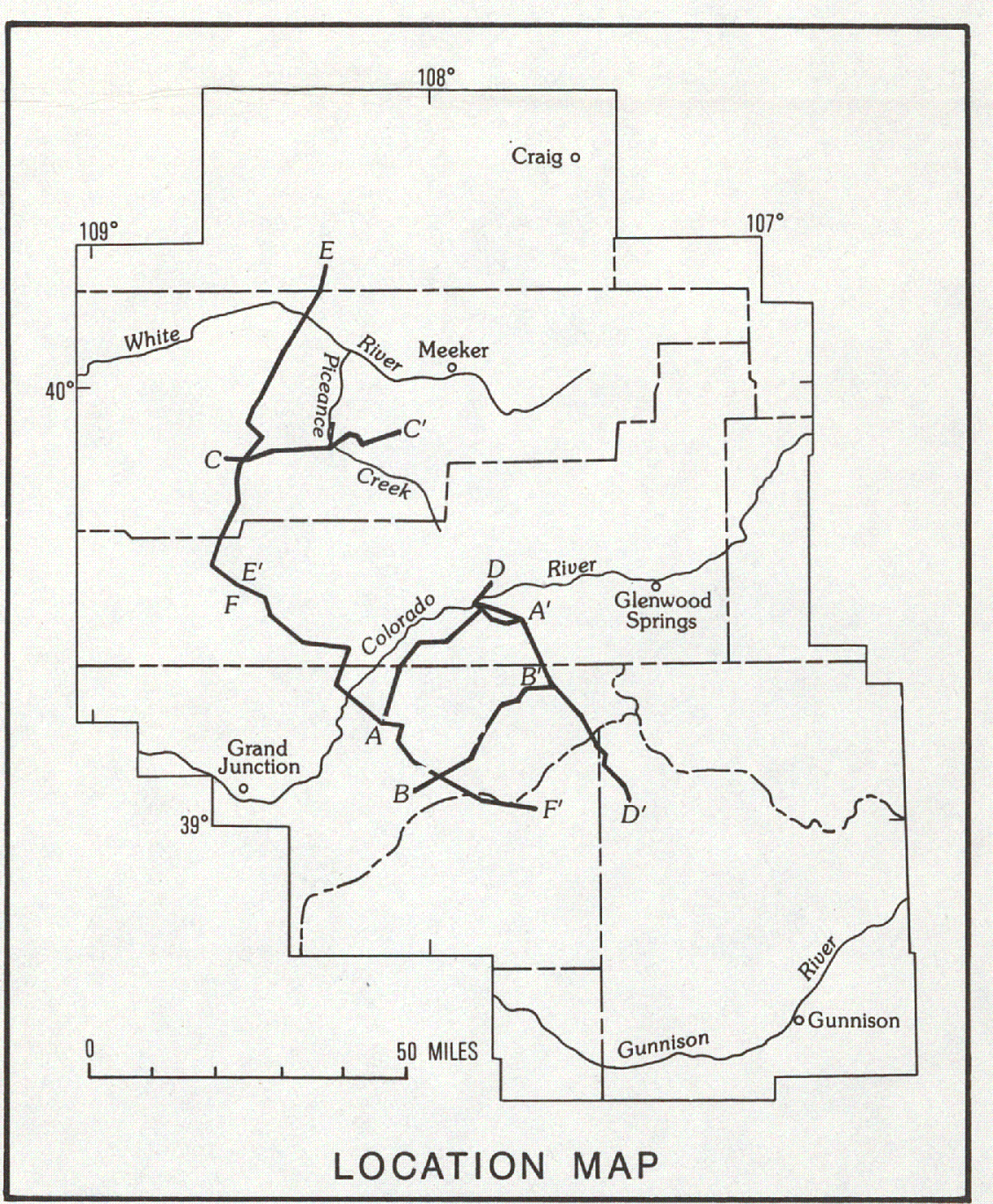





